
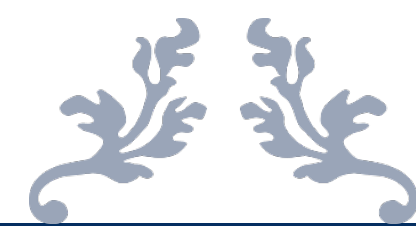

\title{
Bog Bodies: Archaeological Narratives and Modern Identity.
}

\section{By Lydia Stewart}
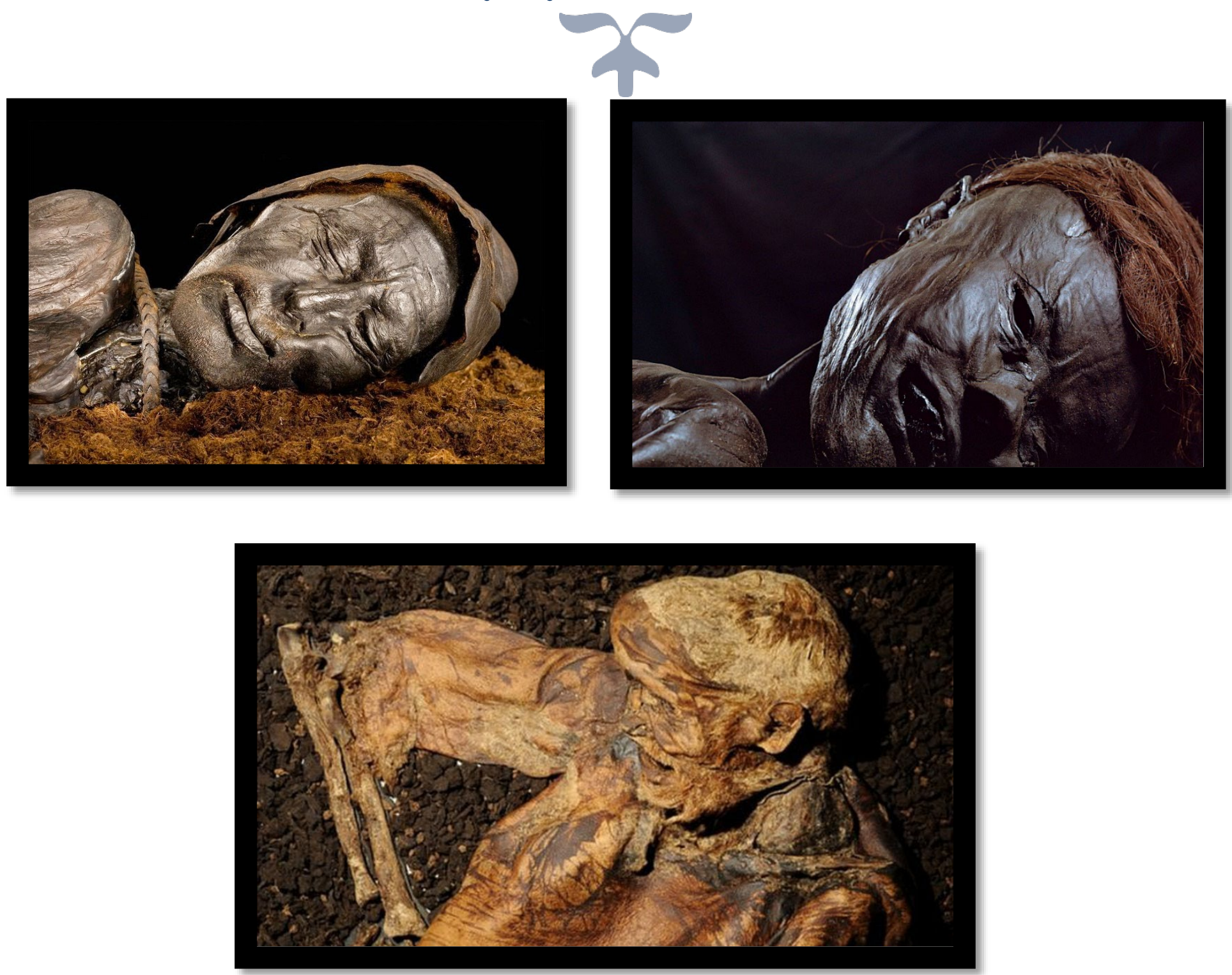

A THESIS SUBMITTED TO

VICTORIA UNIVERSITY OF WELLINGTON

IN FULFILMENT OF THE REQUIREMENTS FOR THE DEGREE OF MASTER OF ARTS 


\section{ABSTRACT}

Bog Bodies: Archaeological Narratives and Modern Identity.

By Lydia Stewart

Lindow Man, the British Bog Body discovered in 1984, and the Danish examples Tollund and Grauballe Men, discovered in 1950 and 1952, represent quite literally the violent face of a confrontational past. But what exactly do the archaeological narratives say? When presented with the forensic evidence can we explicitly conclude they were murdered as human sacrifices to appease the Germanic and Celtic gods and goddesses during times of affliction? Or are they simply an example of our own imposition of modern assumptions onto the past in a flare of sensationalism and mystical dramatization of the tumultuous affairs of noble savages? How have these narratives played out in the public sphere, particularly museum and heritage, and in modern culture such as the Irish poet Seamus Heaney's bog poems. Do they reinforce harmful myths of an excessively violent past dominated by innately uncivilized natives? Who does the past really belong to and who has the authority to voice it? Many facets of bog body scholarship remain hotly contested including the human sacrifice interpretation, the usage of Tacitus as the only remaining historical source and Heaney's use of the bog victims as a metaphorical analogy for the Northern Ireland sectarian violence. My contribution is precisely to present these interpretational narratives from a critical perspective and question scholarly assumptions of ritualism. Further, I will explore how archaeological narratives are presented to the public through the unique heritage that bog bodies embody. Lastly, I will investigate the conceptualization of the "other" through Tacitus' Germania and Heaney's bog poems. 


\section{Acknowledgements}

I would like to acknowledge my vast support network without whom this would not be possible. First and foremost, to Marco Sonzogni for encouraging me to undertake this project and believing in my abilities, and to my other supervisors Diana and Jeff for all their fantastic guidance, much needed encouragement and advice throughout. I would also like to thank Isabella Mulhall at the National Museum of Ireland for her incredible generosity in taking the time to speak with me and going out of her way to provide me with extra resources and images, along with both the Silkeborg and Moesgaard Museums. Furthermore, I would like to acknowledge my mum, Suzanne for her relentless belief, unyielding encouragement and sharing in my achievements and my dad, Bruce for all his encouragement and support. Lastly, I would like to thank my good friends Maddy, Amy and Paul and my proof-reader Ted for their untiring efforts and as soundboards of my manic ramblings. Without you all I would not have been able to develop and express my ideas as deeply as I have. A piece of each of you all is threaded into the fabric of my work. 


\section{Table of Contents}

INTRODUCTION

\section{CHAPTER 1}

TOLLUND AND GRAUBALLE: THE BIRTH OF MODERN ARCHAEOLOGICAL

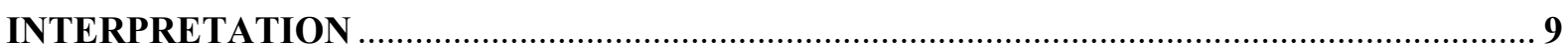

THE DISCOVERY AND CONSERVATION OF TOLLUND MAN ....................................... 11

THE DISCOVERY AND CONSERVATION OF GRAUBALLE MAN .................................... 15

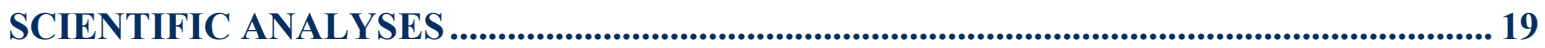

ANALYSES AND PATHOLOGY OF TOLLUND MAN..................................................... 19

INITIAL ANALYSES AND PATHOLOGY OF GRAUBALLE MAN ...............................21

RE-EXAMINATION OF INITIAL ANALYSES ............................................................... 24

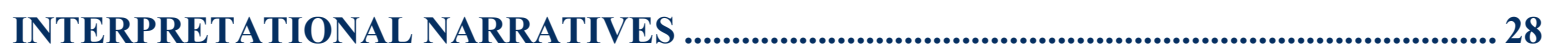

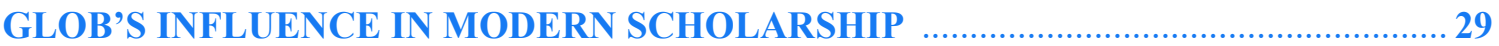

\section{CHAPTER 2}

LINDOW MAN: ARCHAEOLOGICAL NARRATIVES AND MODERN IDENTITY .............34

THE DISCOVERY OF LINDOW MAN ….................................................................................... 36

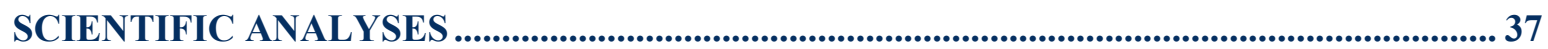

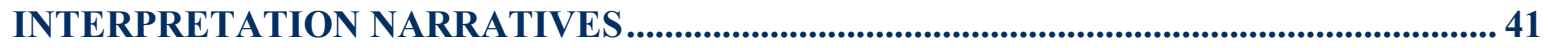

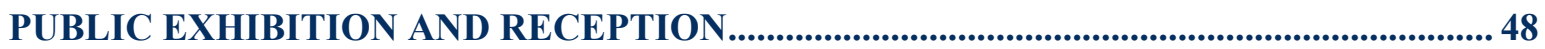

MANCHESTER MUSEUM'S 'LINDOW MAN: A BOG BODY MYSTERY' ................50

\section{CHAPTER 3}

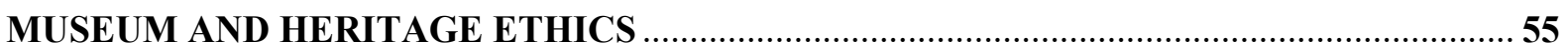

DISTURBANCE OF THE DEAD ................................................................................................... 57

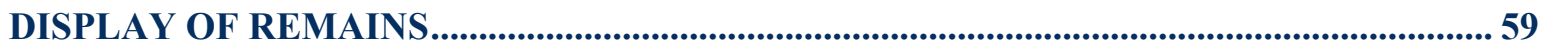

BUILDING APPROPRIATE EXHIBITIONS FOR REMAINS............................................... 62

TWO CASE STUDIES: THE BRITISH MUSEUM AND THE NATIONAL MUSEUM OF

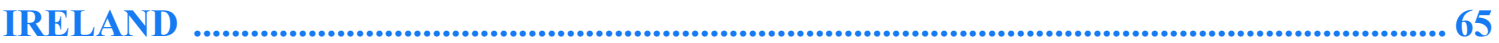

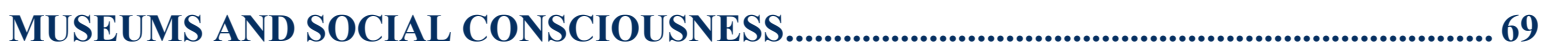

\section{CHAPTER 4}

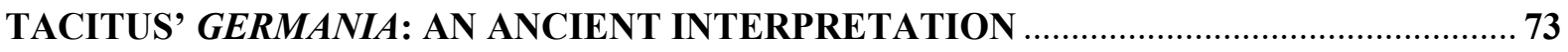

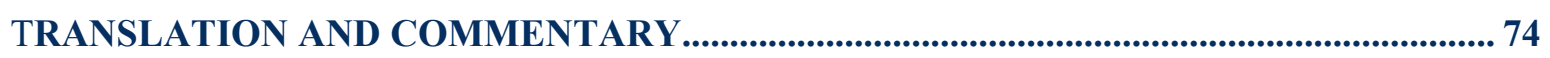




\section{CHAPTER 5}

SEAMUS HEANEY'S BOG POEMS: A MODERN INTERPRETATION.................................. 87

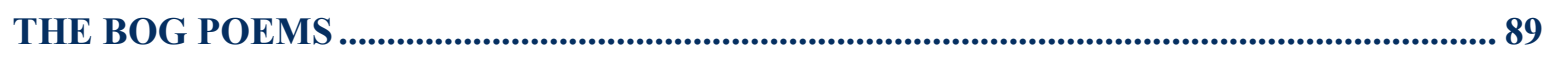

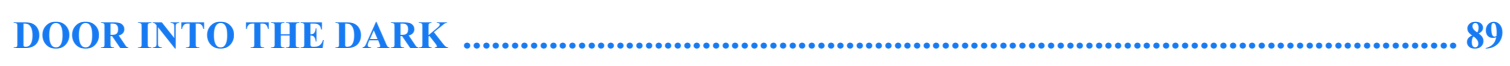

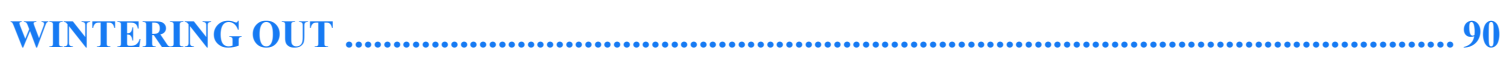

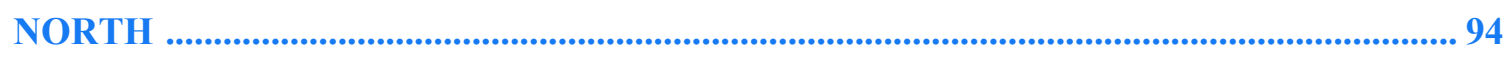

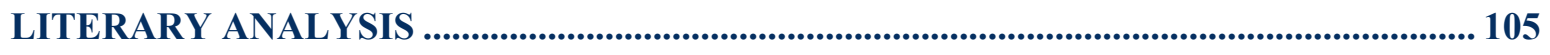

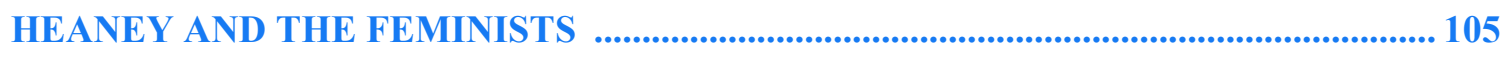

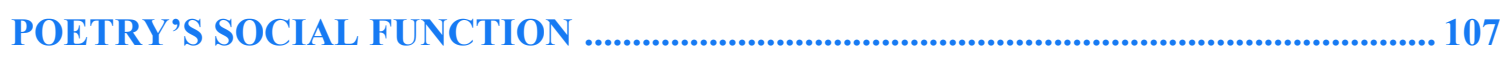

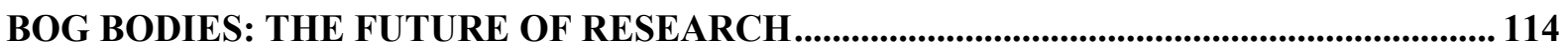

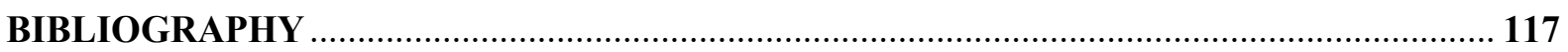




\section{Introduction}

Bog bodies, also known as bog people, are the phenomenon of human cadavers naturally mummified in peat bogs. They typically exhibit signs of extreme violence or "overkill," meaning the use of unnecessarily excessive force to kill. The first usage of the term "bog bodies" was by Professor of Archaeology and History Johanna Mestorf in 1871. In 1972 Alfred Dieck cataloged 1,850 bodies discovered, many of which were likely reburied in Christian cemeteries, improperly conserved and forgotten in storage or ground into mummy powder and consumed as medicine. Although Dieck's estimate has been since invalidated as highly exaggerated, the number of current and previous bog bodies is unknown with many forever lost. Due to the lack of oxygen, acidity of the bog and sphagnum moss, the soft tissues such as skin, hair and nails survive but bones typically decalcify. Preservation levels vastly vary from near perfect to purely skeletal. The presence of sphagnum moss in the upper layers creates an anaerobic environment $50 \mathrm{~cm}$ below the surface, immobilizing the exoenzymes secreted by putrefaction bacteria. It also binds calcium ions (chelates), making bones pliable or absent while the skin is stabilized through cross-linking of collagen helical molecules. The brown pigmentation is a result of protein hydrolysis ('Milliard reaction') wherein smaller peptide fragments combine with carbohydrates. This both demineralizes and renders the skeleton fragile, now solely supported by desiccated leathery skin and ensures complete visceral structural degeneration. Skin is the last tissue to desiccate, only after no residual water resides in the deeper tissue. Enzymes in the emerging water causes the epidermal keratin to slough off as the anterior wall is exposed for the longest period, hence the smoothness of their hands. This has been used to suggest an apparent lack of hard labour indicating aristocratic status. ${ }^{1}$ Purdy illustrates how the specificity of bogs "resides in their extraordinary power to abolish temporal distance...To compress time, collapsing centuries into hours and years into minutes... They render the distant past immediate and breathe

\footnotetext{
${ }^{1}$ David Keys, "Europe's First Mummies." Archaeology 56, no. 5 (2003): 16-17, Arthur Aufderheide, "Soft Tissue Taphonomy: A Paleopathology Perspective," International Journal of Paleopathology 1, no.2 (October 2011): 78, John Mitchell, "Role of Polysaccharides in the Preservation of Bodies in Peat," Polymers 29 (1996): 193, Niels Lynnerup, "Bog Bodies," The Anatomical Record 28, no.6 (May, 2015):1008.
} 
unsuspected life into the abstractions of history and eternity."2 In fact, bodies are often so well preserved, they are mistaken for modern victims. The interment of bodies in bogs is spatially and temporally extensive, spanning throughout northwest Europe (Denmark, Germany, The Netherlands) as well as the UK and Ireland dating from approximately 2000BCE-400CE. The continuation of repeated location as well as expansive geographic distribution suggests votive deposition, inferring ritualization. Ritualization is further inferred by association with other votive deposits present in the record such as a vast array of $1^{\text {st }}$ millennium plows, dress fittings, clothing, wagons, cauldrons, weaponry such as leather shields and swords, gold torques, wooden statuettes, pots, scabbards, chapes, spearheads, wooden knives, bridle parts, yokes, drinking vessels and butter, all items of great prestige. Previous scholarship has been primarily concerned with dating which exhibits the widespread extent of deposition throughout northern Europe in the Late Bronze Age and Early Iron Age, but even more recently into the medieval period. This study focuses on three case studies in particular: the Danish examples of Tollund and Grauballe Men, discovered in 1950 and 1952, and Lindow Man, the British bog body discovered in 1984, who represent quite literally the violent face of a confrontational past. But what exactly do the interpretational narratives say? Mestorf was the first to relate the bog bodies to Tacitus' social ritual theory interpretation in the Germania, chapter 12, which depicts the deposition of people in bogs as punished social outcasts. In 1922 German Historian Karl Von Amira expanded this to include human sacrifice for divine rectification based upon the use of restraints, excessive violence and denial of burial. ${ }^{3}$ Danish Archaeologist P.V. Glob quickly accepted this and modern scholarship has predominantly conformed to Glob's forefront publication of The Bog People in 1965. He speculated Tollund and Grauballe Men were sacrificial offerings to the fertility goddess Nerthus, dubiously based on the Germania, chapter 40. This was part of larger ceremonial nuptials between the goddess and her priest, consecrated in death for the ensured survival of the community. The question of Tacitus as a historically accurate basis for archaeological interpretation is brought into question through his acute bias, steeped in exaggerated ethnographic generalizations and an agenda to unveil the degeneracy of his own society. In recent times the ritualistic human sacrifice interpretation has been hijacked by scholars such as Aldhouse-Green and Ross, dominating discussion and homogenizing vast

\footnotetext{
${ }^{2}$ Anthony Purdy, "Unearthing the Past: The Archaeology of Bog Bodies in Glob, Atwood, Hébert and Drabble," Textual Practice Vol. 16. (2002): 447.

${ }^{3}$ Morten Ravn, "Bog Bodies-A Burial Practice during the Early Iron Age?” in The Iron Age on Zealand; Status and Perspectives, ed. Linda Boye (Copenhagen: The Royal Society of Northern Antiquaries, 2011), 108-110.
} 
spatial-temporal diversity into a pan-European phenomenon. However, when presented with the forensic evidence can we explicitly conclude they were murdered to appease the Germanic and Celtic gods during times of affliction? Or are they simply an example of our own imposition of modern assumptions onto the past in a flare of sensationalism and mystical dramatization of the tumultuous affairs of noble savages? In the case of Lindow Man, within the context of Glob's pre-established interpretational framework, empirical evidence has been manipulated to resemble the notion of overkill which led to the uncritical assumption of human sacrifice. Yet a recent revision by Lynnerup and Asingh to Grauballe Man's pathology has illuminated the danger and commonality of pseudo-pathology and redistributed the presence of excessive violence to post-mortem diagenesis, undermining the question of 'overkill.' This severely impacts the ritualistic aspect of the killings which relied upon the notion of overkill to justify its existence. This is significant in that the dominant human sacrifice narrative, based predominantly on the notion of ritualistic overkill, characterizes the ancient natives as savages and perpetrates the evolutionary myth of an inherently violent past that infers an innately uncivilized indigenous nature by modern standards. The possibility of human sacrifice is not altogether negated as it was undeniably practiced, although it has been unnecessarily exaggerated in scholarship. This begs the question of how archaeological narratives have played out in the public sphere, particularly museum and heritage and in modern culture, for example in the Irish poet Seamus Heaney's bog poems. Specifically, the heritage of bog bodies raises questions surrounding who the past belongs to and who has the authority to voice it. Exhibition of bodies should be undertaken with public consideration, sensitively and without compromising authenticity. If not, museums risk objectifying the bodies, undermining their educational value and fetishizing death. Two examples are the British Museum's display of Lindow Man and the National Museum of Ireland's exhibition 'Kingship and Sacrifice.' The former adopts a largely one-dimensional exhibition and only a partially empathetic display of remains while the latter establishes a sensitive display of remains and a multi-dimensional, interactive exhibition grounded in cultural context. Another example is the Manchester Museum's 2008 exhibition 'Lindow Man: A Bog Body Mystery' which incorporated ample public consultation and a multi-sensory exhibit encompassing the voices of archaeologists, a peat cutter, the Druid Network, museum curators and locals. Heaney further explores bog bodies' unique role in modern heritage and identity construction and queries whether digging up the past gives voice to ourselves or our ancestors through his series of 'bog poems.' The bog poems illustrate Ireland's and the poet's identity crisis during the Northern Ireland Troubles. In the bog bodies Heaney discovered "befitting emblems for 
adversity," likening the bog victims to the Troubles casualties trapped by the brutal religious ideologies of both the Irish Catholic and Ulsterman Protestant which demand blood in return for the promise of a better future. He utilizes the metaphorical comparison between Iron Age Jutland and $20^{\text {th }}$ century Northern Ireland to explore the underlying psychology of perpetrators in order to identify, address and then break the cycle of violence. These interpretational narratives or 'myth' as Heaney refers to it, serves for him not as an archaeological treatise, but as a tool for cultural restoration and construction of modern identity based on renewal of the past. He recognizes the past as an inseparable extension of the present. I believe Heaney has achieved a realization modern scholarship is yet to; to build positivity and hope and to recognize the past as a constructed narrative of the present. This highlights the most important aspect of bog bodies-they encourage us to explore different understandings of the world, alternative kinds of humanity and most of all to challenge our own attitudes towards life and death. 


\section{Tollund and Grauballe: The Birth of Modern Archaeological Interpretation}

\section{Introduction}

Tollund and Grauballe Men serve as the first of many well-known examples of exceptionally preserved and culturally captivating bog bodies. Tollund Man was discovered in $1950,10 \mathrm{~km}$ west of Bjaeldskovdal and was romanticized by charismatic Danish Archaeologist P.V. Glob as 'sleeping in silent prayer.' The enamoured media deemed him 'the man from Bogville.' Bog body fever was further ignited in 1952 by Grauballe Man's discovery. He was publicly unveiled promptly after excavation to a monumental 18,000 people over the short span of 10 days. They arrived in the heart of a post-war melancholy as the nation strived to establish national identity. They provided the cultural fodder to foster national romanticism as a tangible representation of the Danish mentality in sacrificing for love. Both were thoroughly subjected to much investigation, including isotopic diet reconstruction, radiography, Computer Tomography, 3D visualization and stereolithography. In 2014 Charlier detected elevated plantar formations on the bottom of Tollund Man's feet suggestive of the papillomavirus (warts), one of the rarest records of a prevalent prehistoric malady. Radiocarbon dated to the $4^{\text {th }}$ century BCE (405-380BCE), he was hung by the noose discovered around his neck but without any damage inflicted on the vertebrae. Therefore, strangulation was ruled as the cause of death. He was discovered naked excepting a hide hat and a belt. In 2001-02 a revision of the original 1952 investigations of Grauballe Man was carried out, in addition to an all-encompassing new investigation utilizing current technological methodologies. He was revisionally dated to $390 \mathrm{BCE}$ at $95 \%$ confidence. Greater precision and accuracy allowed scholars Lynnerup and Asingh to re-evaluate the original pathologies concluded by Helbaek in 1952. Helbaek's three main traumas identified were a blunt force cranial fracture, a fracture of the left tibia and a severe throat laceration, which severed both the jugular and carotid arteries, esophagus and hyoid bone, exposing the tongue, epiglottis and larynx. Helbaek also conducted a deconstruction of both Tollund and Grauballe Men's' last meals. The latter contained a small amount of the hallucinogen ergot, leading to ritualistic speculation despite Helbaek's own confirmation of its harmlessness. 
However soon ritualization ran rampant. With the unveiling of the bog men, Glob sought to perpetuate a narrative intertwining the Danish landscape and social memory rooted in antiquity and steeped in tradition. He alleged that they were sacrificial offerings to the fertility goddess Nerthus as described in Tacitus, during the cycle of the spring wedding, symbolizing the union between earth and sky. The victims, husbands to the goddess during the springtime feasting, were consecrated in death to her forever. He believed them to be willing Druids or voluntary aristocrats unaccustomed to toil or even picked by lot and condemned to death. This narrative has been regurgitated over time by such scholars as Aldhouse-Green and Ross. However, in recent scholarship the nature and extent of violence has faced scrutiny under the lens of Giles, Chapman and Gearey. Although all scholars agree that there is no universal explanation, Glob's generalized interpretations still prevalent today serve to undermine vast spatial-temporal diversity and seem counterintuitive to scholarly discussion. 


\section{The Discovery and Conservation of Tollund Man}

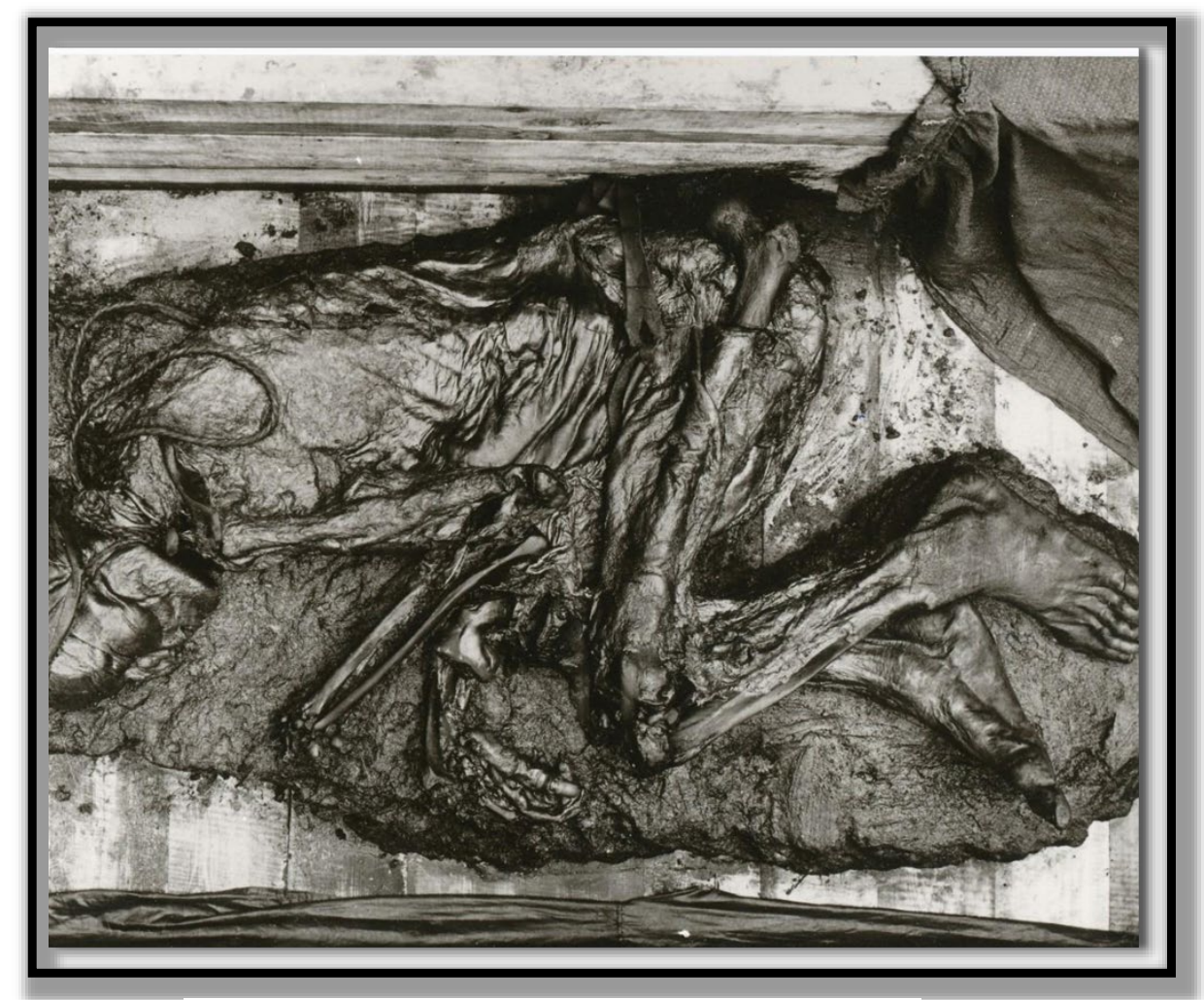

Figure 1: The Tollund Man- the whole body.

Photo Lennart Larsen, viewed 19 August 2020

https://samlinger.natmus.dk/DO/asset/10895

\section{Discovery}

On the $8^{\text {th }}$ of May 1950 the Silkeborg police received a message that the two brothers Viggo and Emil Hojgaard had discovered a body two days prior in a raised bog in Bjaeldskovdal, $10 \mathrm{~km}$ west of Silkeborg, central Jutland. The peat cutters had discovered what was believed to be a recent murder victim, a schoolboy missing from Copenhagen. Tollund Man was named after Tor's grove where he was found deliberately placed in a peat-cutting seven feet deep. Interred naked, wearing only a pointed skin hat fastened under the chin and a leather belt, he sported short-cropped hair gathered in a knot at the back. Around his neck a meterlong rope was coiled over his shoulder, suggesting he was hanged. Glob, the DirectorGeneral of Museums and Antiquities of Denmark and the first archaeologist on the scene, remarked how he "lay in a damp bed as though asleep... his face wore a gentle expression-the 
eyes lightly closed, the lips softly pursed, as if in silent prayer."4 Arranged with respect, his closed eyes seemingly erased his violent death. ${ }^{5}$

\section{Climate/Environment}

He was located in a narrow valley leading into lake Bolling, yet during the Iron Age the lake was much smaller and consisted mostly of bogland. The Iron Age was significantly wetter and cooler than the Bronze Age as the water table rose and low-lying areas were transformed into bogs. Reduced solar activity and increased cosmic radiation caused a greater proportion of atmospheric carbon, influencing cloud formation, and reinforcing changes in solar wind. This altered ocean currents in the north Atlantic and resulted in forceful abandonment of settlements. ${ }^{6}$ During this time of change, the bog represented raw exploitable material and a place where the supernatural reigned, evidenced by a sudden change in behaviour in the archaeological record, possibly indicating a

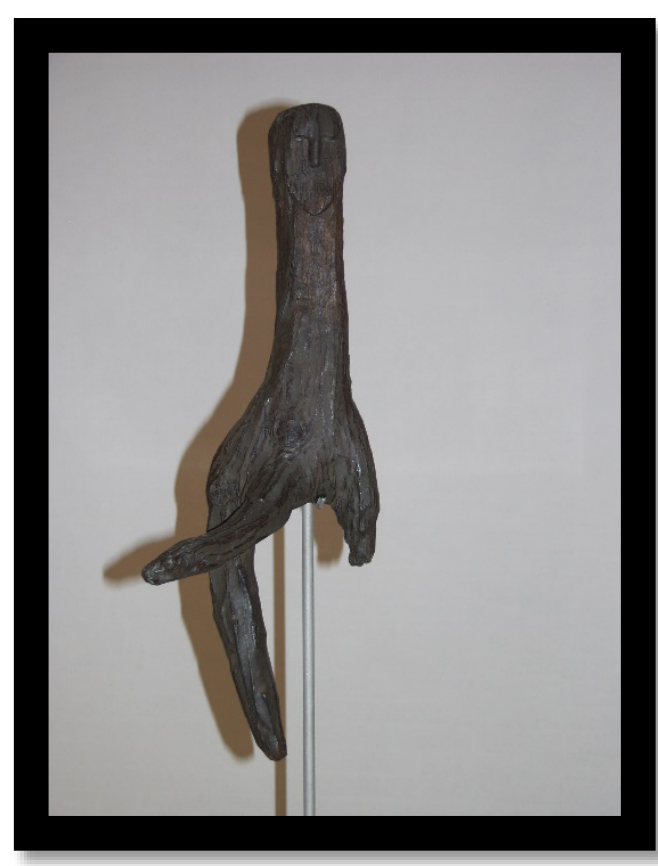

Figure 2: Broddenbjergmanden.

An example of a votive figure found in the bog. Photo Museum Silkeborg.

shift in religious perception. Permanent depositional loci were established and frequented more thoroughly. New rituals arose and offerings formed a part of the celebrations along with feasting, evidenced by bones and vessel votive deposits near wooden figures (figure 2 ). ${ }^{7}$ The concept of the bog as a mystical and sacred space will be further explored and remains contentious.

\footnotetext{
${ }^{4}$ P.V. Glob, The Bog People: Iron Age Man Preserved (New York: Faber \& Faber, 1965), 18.

${ }^{5}$ Miranda Aldhouse-Green, Bog Bodies Uncovered; Solving Europe's Ancient Mystery (London: Thames \& Hudson, 2015), 20, Nina Nielson et al., "Diet and Radiocarbon Dating of Tollund Man: New Analyses of an Iron Age Bog Body from Denmark," Radiocarbon 60, no. 5 (June 2017): 1533, S. Jarcho, "Tollund Man and Other Bog Burials," Bulletin of the New York Academy of Medicine 46, no. 7 (July 1970): 554-6, Glob, The Bog People, 18, 20, 25, 28, 31, “The Discovery of Tollund Man,” Museum Silkeborg, accessed June 30, 2019, http://www.museumsilkeborg.dk/the-discovery-of-tollund-man.
}

\footnotetext{
${ }^{6}$ Pauline Asingh, Grauballe Man-Portrait of a Bog Body (Copenhagen: Gyldendalske, 2009), 173-4, $176,179$.

${ }^{7}$ Nielson et al. "Diet and Radiocarbon Dating of Tollund Man," 1534-5, Asingh, Grauballe Man, 173-4, 176, 179, 194, 201, 205, Chiara Villa, Niels Lynnerup, "Hounsfield Units Ranges in CT-scans of Bog Bodies and Mummies," Anthropologischer Anzeiger 69, no.2 (March 2012): 134,136, Van Der Plicht et. al., "Dating Bog Bodies by Means of 14C-AMS," Journal of Archaeological Science 31 (2004): 471-2.
} 


\section{Excavation}

A box was constructed around the body in-situ as it rested on its peat bed, the bottom inserted underneath. Weighing half a tonne, he was then transported via horse and carriage to Moselund station and then by train to the Danish National Museum in Copenhagen wherein he was excavated from his peat-block under controlled conditions. ${ }^{8}$

\section{Conservation}

Danish scientists had never before been faced with the task of preserving an entire body. The Silkeborg Museum was keen to preserve him entirely, but the National Museum deemed this both too difficult and too macabre for display. Therefore, the head and right foot only were selectively preserved. Beeswax and bacteriostatic liquid was deemed a suitable substitute for bog water owing to its non-perishability and low viscosity. The head was immersed for six months in a watery solution containing formalin, acetic acid, tannic oils, oak bark extracts and toluol. The water was replaced by $30 \%$ alcohol, gradually increased to $99 \%$. Despite a $12 \%$ shrinkage, the features remained immaculately preserved. ${ }^{9}$

\section{Exhibition}

Purdy believes his "amazing state of preservation renders him emblematic of the powerful tensions between economic and scientific rationality on one hand and magico-religious perceptions of the natural world on the other." 10 This is captured in the Silkeborg Museum's display resembling a peat bog. The sole occupant Tollund Man is housed inside a softly lit glass case, lying upon his peat bed against a photo panel background of the find site. The stillness of presence contributes an aura of reverence and meditational reflection, invoking more spiritual pilgrimage than scientific institution. ${ }^{11}$

\footnotetext{
8 "By Horse-Drawn Carriage and Train to the National Museum," Museum Silkeborg, accessed June 30, 2019, http://www.museumsilkeborg.dk/by-horse-drawn-carriage-and-train-to-the-national-museum.

${ }^{9}$ Nielson et al. "Diet and Radiocarbon Dating of Tollund Man," 1534-5, Glob, The Bog People, 15, Lynnerup, "Bog Bodies," 1008, Villa and Lynnerup, "Hounsfield Units Ranges," 134, 136, "By Horse-Drawn Carriage and Train to the National Museum," Museum Silkeborg, accessed June 30, 2019, http://www.museumsilkeborg.dk/by-horse-drawn-carriage-and-train-to-the-national-museum, "Preservation of Tollund Man," Museum Silkeborg, accessed June 30, 2019, http://www.museumsilkeborg.dk/preservation-oftollund-man.

${ }^{10}$ Purdy, "Unearthing the Past," 445.

${ }^{11}$ Purdy, "Unearthing the Past," 445.
} 


\section{Demography in the record}

At 5 feet 2 inches tall, dating to $405-380 \mathrm{BCE}$, and at 30-40 years old Tollund Man fits within the typical pattern of other Iron Age bodies, 14 of which have been sexed, six aged. Five of which died violently; three hanged, one cut-throat, one blunt force trauma and all deaths were untimely. All were deposited naked and appeared to have lived lives of apparent luxury. Variation in deposition is problematic with some in watery deposits, others in peat cuttings. His discovery was met with great excitement both scientific and public alike. He was dubbed by local newspapers as "the man from Bogville" and ushered in a new era of multidisciplinary analyses and technological methodologies. ${ }^{12}$

\footnotetext{
${ }^{12}$ Aldhouse-Green, Bog Bodies Uncovered, 20, 201, Jarcho, "Tollund Man and Other Bog Burials," 554-5, Heather Gill-Robinson, The Iron Age Bog Bodies of the Archaeologisches Landesmuseum, Schloss Gottorf, Schleswig, Germany (ProQuest Dissertations Publishing, 2005), 52-4, Museum Silkeborg, "The Discovery of Tollund Man." Purdy, "Unearthing the Past" 445, Parker-Pearson, "Lindow Man and the Danish Connection: Further Light on the Mystery of the Bogman," Anthropology Today 2, no.1 (Feb 1986):16-7, Lynnerup, "Bog Bodies," 1008, Glob, The Bog People, 28, 31, Paul Bahn, "Through Nature to Eternity; the Bog Bodies of Northwest Europe by Wijnand van der Sanden.” Archaeology 50, no.4 (July 1997): 63, 65.
} 


\section{The Discovery and Conservation of Grauballe Man}

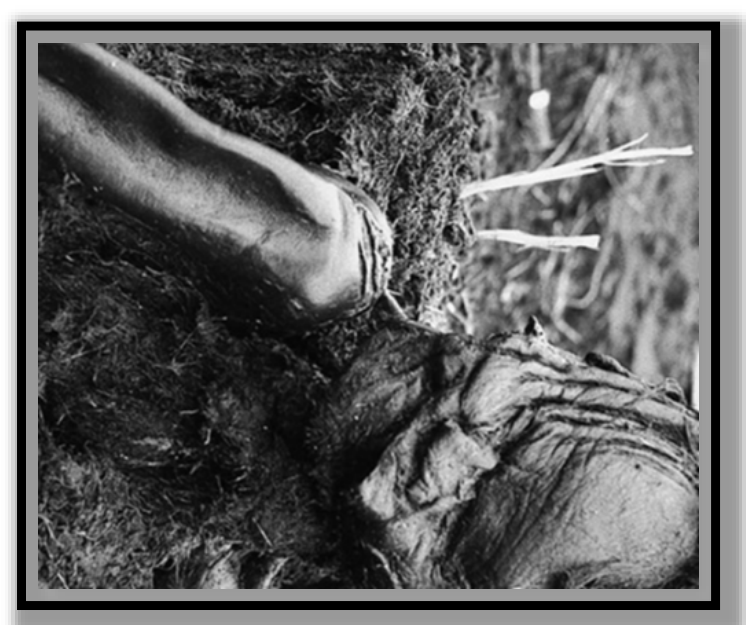

Figure 3-Grauballe Man.

Photo Museum Moesgaard, viewed 25 August 2020.

https://www.moesgaardmuseum.dk/media/4768/grauballemande

\section{Excavation}

n-neg-18.jpg

On the $26^{\text {th }}$ April 1952 Grauballe Man was unearthed by peat cutter Tage Sorensen in Nebelgaard Mose. Glob recalled the sight of him, in contrast to Tollund Man, as wearing an expression not of tranquillity but pain and terror. This sentiment derived from the puckered forehead, contorted eyes and mouth and twisted posture. He was discovered deposited naked only one meter deep, similarly in an old peat cutting with his throat slashed and head bent backward as a clear execution. The awkward supine burial position and lack of decomposition suggests deposition prior to the onset of rigor mortis. Plant tissue had penetrated the body, making dating difficult to determine, but the most recent date concludes 390BCE with 95\% confidence. Grauballe Man was uncovered with two-three weeks of facial growth on his upper lip and chin, an open mouth containing black, worn teeth and $15 \mathrm{~cm}$ long originally dark hair. ${ }^{13}$ A height of $165-170 \mathrm{~cm}$ was determined from the maximum lengths of

\footnotetext{
${ }^{13}$ Aldhouse-Green, Bog Bodies Uncovered, 19, Glob, The Bog People, 39, Hans Stodkilde-Jorgensen et al., "The Intestines of a More than 2000 Years Old Peat-Bog Man: Microscopy, Magnetic Resonance Imaging and 14C-Dating," Journal of Archaeological Science 35 (London: 2008): 533, Niels Lynnerup, "Methods in Mummy Research," Anthropologischer Anzeiger 67, no. 4 (2009): 361, Markil Gregersen et al., "Forensic Evidence, Injuries and Cause of Death," in Grauballe Man: An Iron Age Bog Body Revisited, eds. Pauline Asingh, Niels Lynnerup (Jutland: Narayana Press, 2007), 234, Pauline Asingh, "The Man in the bog," in Grauballe Man: An Iron Age Bog Body Revisited, eds. Pauline Asingh, Niels Lynnerup (Jutland: Narayana Press, 2007) 17, 21-5.
} 
the tibia and femur, making him slightly smaller than his contemporaries. However, nothing was found to distinguish him as separate from the early Iron Age population. His fused clavicles indicate an age of 26-30 years old. A transitional analysis was performed on the anatomical sutures (pubic symphysis, auricular surface and cranium) which resulted in three ages with a mean of 28.66. ${ }^{14}$ Excavated similarly to Tollund Man, he was transported to the Prehistoric Museum of Aarhus on the $27^{\text {th }}$ of April. Glob maintained the intention to fully preserve him. He was laid out, covered with saturated sacks and sprayed with distilled water. $^{15}$

\section{Initial Display}

Due to popular demand with a nation gripped by bog body fever, Grauballe Man was put directly on display. At this time, it was considered both unethical and offensive to display remains. Despite this and amongst raging debate for a Christian reburial, acceptance was gained from Reverend Moller Rasmussen of Svostrup Parish for display. Resulting in a great success with enormous interest from old, young, men, women and school children queuing the length of the street, the exhibit originally planned for just

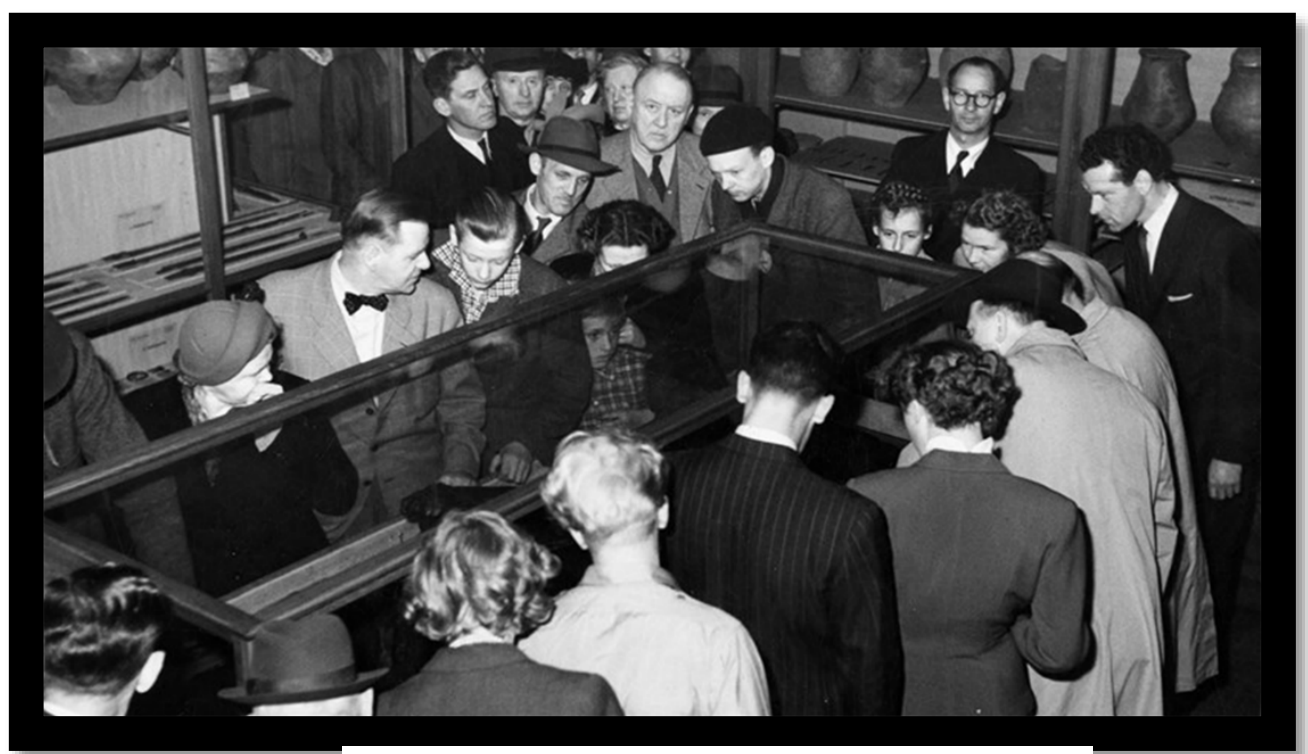

Figure 4-Grauballe Man on display, 1952.

Photo Museum Moesgaard, viewed 25 August 2020.

https://www.moesgaardmuseum.dk/media/4773/gr auballe papirbilleder 213 .jpg 10,000 throughout. During the subsequent 10 days he was kept damp with a $0.5 \%$ phenol solution applied daily. The hygrometer case measured 66-96\% RH (relative humidity) with extreme fluctuations and after seven days

\footnotetext{
${ }^{14}$ Jesper Frederiksen, Jens Glastrup. "Conservation and Analysis of Grauballe Man 2001-2002," in Grauballe Man: An Iron Age Bog Body Revisited, eds. Pauline Asingh, Niels Lynnerup (Jutland: Narayana Press, 2007), 59, 63, 66, Niels Lynnerup et al., "The Biological Anthropology of Grauballe Man," in Grauballe Man: An Iron Age Bog Body Revisited, eds. Pauline Asingh, Niels Lynnerup (Jutland: Narayana Press, 2007), 226-8, 230-3.

${ }^{15}$ Helle Strehle. "The Conservation of Grauballe Man," in Grauballe Man: An Iron Age Bog Body Revisited, eds. Pauline Asingh, Niels Lynnerup (Jutland: Narayana Press, 2007), 33-6.
} 
mould was discovered. By now he had become a national treasure and undisputed major public attraction. ${ }^{16}$

\section{Conservation}

With the initial exhibition concluded, attention was turned to conservation efforts. In light of Tollund Man, Conservator Lange-Kornbak opted for a natural methodology; completing the tanning process begun by the bog to preserve the entire body. The chest was stuffed with a bark mixture while the body was wrapped in linen and laid into a box with bark packed tightly around it. It was immersed for 18 months in a solution of one-third fresh oak and twothirds oak bark with $0.2 \%$ toxinol disinfectant. This was changed three times; the first batch lasted three months, the second and third eight months each with three-week intervals inbetween. On the $2^{\text {nd }}$ of June, 1954 commenced his immersion in 10\% Turkish red oil, glycerine, cod liver oil, lanolin and distilled water for one month. His hands and feet were injected with a coagulating substance. Extensive remodeling of shrunken muscles was undertaken for aesthetic purposes. The permanent exhibition commenced in $1955.6 \%$ shrinkage occurred over the first 20 years and a further $3 \%$ over the subsequent 30 due to desiccation through the evaporation of applied oils. Oxidative degradation of surface skin combined with the use of vegetable tanning agents resulted in micro-crack formation. In 1970 the case was fitted with internal lighting, giving rise to circadian heating and regular diurnal fluctuations. The light, RH and air quality were monitored in 2002, with a new oxygen-free, nitrogen case at $55 \% \mathrm{RH}^{17}$

\footnotetext{
${ }^{16}$ Strehle, "Conservation," 33-6, Asingh, Grauballe Man, 20-4, Asingh, "The Man in the bog," 17, 21, Pauline Asingh, Niels Lynnerup. "Foreword," in Grauballe Man: An Iron Age Bog Body Revisited, eds. Pauline Asingh, Niels Lynnerup (Jutland: Narayana Press, 2007), 10.

${ }^{17}$ Asingh, "The Man in the bog," 21-5, 29, Strehle, "Conservation," 33-7, 42- 46, 48, 50, Don Brothwell, The Bogman and the Archaeology of People (London: British Museum Publications, 1986), 21-3, Villa and Lynnerup, "Hounsfield Units Ranges," 136.
} 


\section{Current Exhibit and Display of}

\section{remains}

For the current exhibition in the

Moesgaard Museum, launched in 2002, a new lightweight bed of polycarbonate underlaid with a stainless-steel frame was constructed. The previous bed, constructed from a direct impression of the peat, no longer fitted due to shrinkage. The body was swabbed with ketone to dissolve the oils and fat layers from prior treatments. The new exhibit focuses on the body's altered appearance and chemical composition over time as well

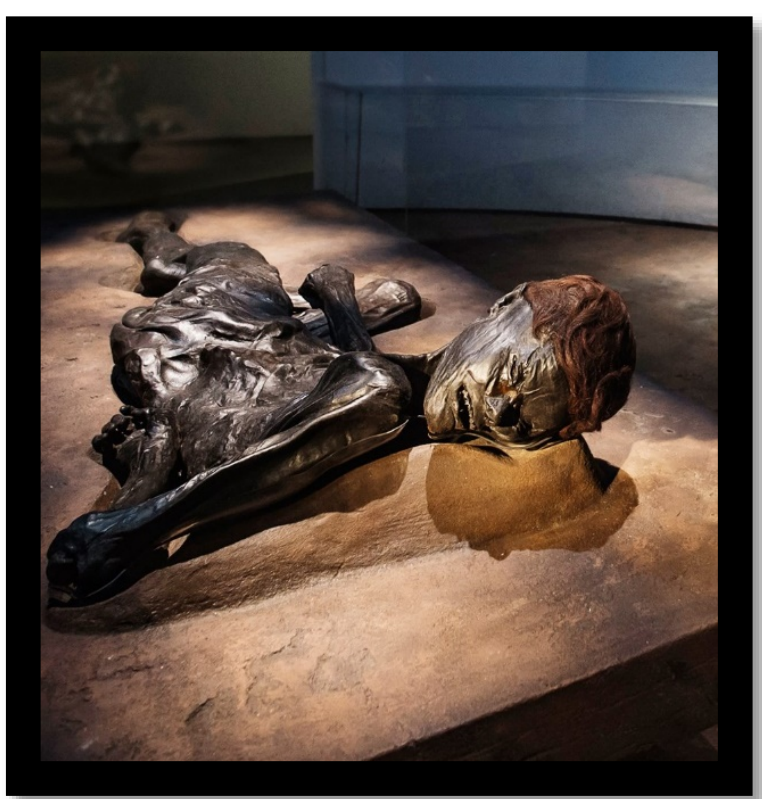

Figure 5-Grauballe Man on display today.

Photo Museum Moesgaard, viewed 25 August 2020.

https://www.moesgaardmuseum.dk/media/2701/momugrauballeman.jpg?height $=1600$ as its preservation for posterity. It includes diverse interpretations projected onto past landscapes re-imaged in the present. New visual media allows the past to be known and experienced in diverse ways, including a microscope to examine a bone sliver from the leg and pollen grains from the stomach, as well as a facial reconstruction. A separate viewing area sensitively displays the remains with associated information in a nearby gallery. His presence is dispersed across diverse media, existing not solely as a physical entity. The new exhibit reveals the crucial interdependence between contemporary experience and investigative techniques, while demonstrating how these actively transform the way in which Grauballe Man is viewed and experienced. ${ }^{18}$

\footnotetext{
${ }^{18}$ Stuart McLean, "Bodies from the Bog: Metamorphosis, Non-Human Agency and the Making of "Collective Memory," Trames 12, no. 3 (2008): 304-5, 307, Don Brothwell, "Grauballe Man: An Iron Age Bog Body Revisited-Review," Antiquity 82 (2008): 227.
} 


\section{Scientific Analyses and Pathology of Tollund Man}

As one of the most highly studied examples, investigations of Tollund Man include CT scanning, radiographs, endoscopy, accelerator mass spectrometry (AMS), isotope analysis and macrofossil analysis of the stomach contents. Initially examined at Bispebjerg hospital in Copenhagen, he was subjected to the most comprehensive and advanced techniques at the time, including police fingerprinting of his right thumb. The forensic examiner's report concluded the noose was used to hang rather than strangle as the cervical vertebrae remained undamaged and exhibited no displacement, dislocation or rupturing of the spinal cord. Thus, he was hanged in a way that resulted in suffocation, cut down, his eyes and mouth closed and gently deposited in the bog. The autopsy revealed healthy, well-preserved lungs, heart and liver. ${ }^{19}$

\section{Diet Reconstruction}

His stomach contents were washed out and an intestinal sample was taken which revealed a gruel of hulled barley and seeds from Camelina, pale persicaria flax, black bindweed, fat hen, corn spurrey and field pansy consumed 12-24 hours pre-mortem. This gruel was reconstructed for a 1950s television program wherein Sir Mortimer Wheeler tasted it and exclaimed it so vile, the wretched man was probably glad to die. In 2018 Nielson et al. were able to conduct strontium and nitrogen isotope analyses on a rib and femur owing to their superior preservation. With agriculture forming the basis of Iron Age subsistence, they expected a terrestrial diet with some possible freshwater fish. They anticipated the rib isotope values to approximate his childhood diet due to shorter turnover and naturally less dense composure and the femur to reflect average adolescence and adulthood diet. The preliminary femoral results indicated Tollund Man lived within 40km of his find site in the last 10 years prior to his death. They concluded that the average diet was reflected equally in both samples which was purely terrestrial. High nitrogen values may be explained by a consumption of manure field-grown crops. ${ }^{20}$ However, Skoglund warns against forming a general picture of

\footnotetext{
${ }^{19}$ Gill-Robinson, The Iron Age Bog Bodies, 52-4, Brothwell, “The Bog Man,” 21-3, 31, Aldhouse-Green, Bog Bodies Uncovered, 68, Glob, The Bog People, 32-3.

${ }^{20}$ Nielson et al., "Diet and Radiocarbon Dating of Tollund Man," 1535-6, 1541. Aldhouse-Green, Bog Bodies Uncovered, 57.
} 
early Iron Age diet from bog bodies, owing to their conceptualization as social deviants. This contrasts to Helbaek's conclusion upon examination of both Tollund and Grauballe Men's' stomach contents, in reflection of average subsistence compared to Early Iron Age sites. Helbaek also noted a lack of diversity between Tollund Man's mere 20 seeds opposed to Grauballe Man's $60 .^{21}$

\section{Dating}

Tollund Man was not officially dated until 1977, 20 years after Grauballe Man. At the time AMS dating was not ideal due to the substantial tissue necessitated. Two muscle samples produced four dates ranging between 243-93BCE. More recently in 2000 Nielson produced three new dates from rib and skin samples, extracting a mean of 405-380BCE within 95.4\% confidence. $^{22}$

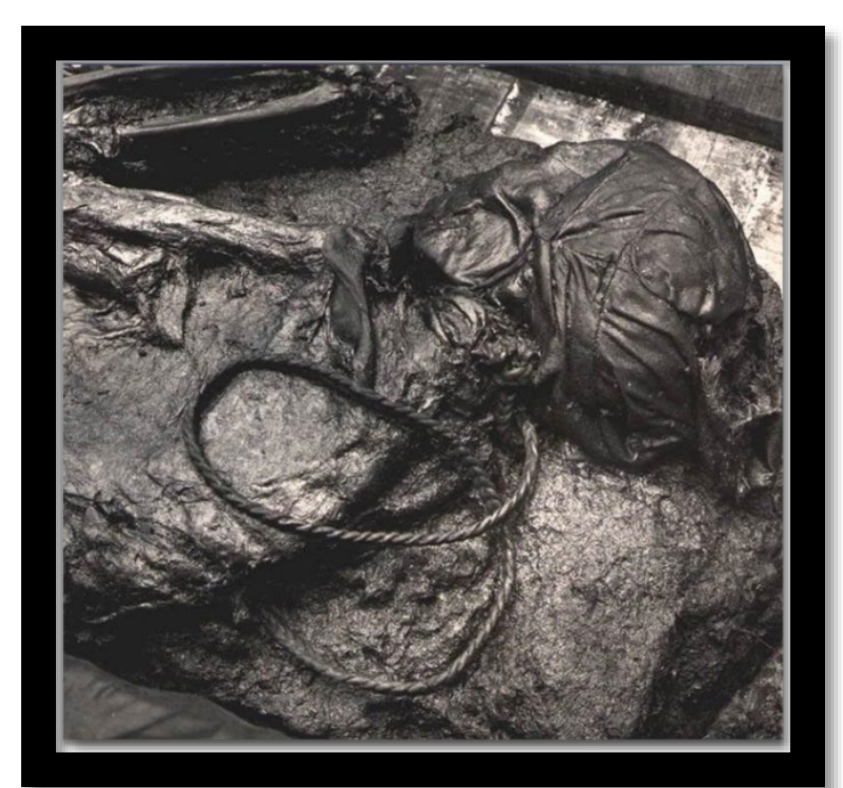

Figure 6:Tollund Man-neckline with rope.

Photo Lennart Larsen, viewed 19 August 2020

https://samlinger.natmus.dk/DO/asset/10885

\section{Paleopathology}

In October 2004 Tollund Man's pathology was re-examined and he was escorted by police to Aarhus hospital where an endoscope was inserted into his head. CT scans revealed a fractured hyoid bone, confirming throttling. An infrared camera revealed a v-shaped neck wound, arousing suspicion of possible lynching. However, Lynnerup warns of the poor visualization issues of CT scanning and radiography when tissue is severely degraded. As bony tissue demineralizes and becomes pliable, it is no longer uniform and may result in a patchy appearance despite remaining morphologically intact, while other tissues, particularly ligaments, become more radio-dense as a result of soil mineral salts in collagenous tissues. He advises CT scans should not be

\footnotetext{
${ }^{21}$ Peter Skoglund, "Diet, Cooking and Cosmology: Interpreting the Evidence from Bronze Age Plant Macrofossils," Current Swedish Archaeology 7 (1999): 152.

${ }^{22}$ Van Der Plicht et. al., "Dating Bog Bodies,"471-2, Nielson et al., "Diet and Radiocarbon Dating of Tollund Man," 1535-6, 1541-3.
} 
viewed as true representations as this may lead to falsely ascribed diagenetic processes. Simultaneously he acknowledges the benefit in visualizing otherwise hidden structures and the ability to reappraise previously ascribed lesions and uncertain traumas. ${ }^{23}$ For example, in 2014 Charlier detected from micro CT, OCT scans and binocular lenses the presence of two $2 \mathrm{~mm}$ elevated plantar formations on both feet, suggestive of the papillomavirus (warts), the oldest ever occurrence on human remains. Warts, rarely documented in the paleo-record, were likely prevalent in ancient times. Through scientific investigation we are better able to grasp the extent minor pathologies impact greater biocultural understanding. It is clear both Grauballe and Tollund Man have definitive signs of execution. Technological methodologies aid in screening and eliminating pseudo-pathologies, providing a better understanding of taphonomic changes. They further provide important information for future assessments which is useful for exhibition construction. ${ }^{24}$

\section{Initial Scientific Analyses and Pathology of Grauballe Man}

Initial investigations of Grauballe Man undertaken in 1952 included fingerprinting, radiography, CT scanning, radiocarbon dating and an autopsy. His fingerprints were identified as double and ulnar loops which appear in the modern Danish population $11.2 \%$ and $68.3 \%$ respectively. Three significant injuries identified were a fractured skull, lacerated throat and fractured left tibia. Palynological analyses revealed early Iron Age (c500BCE) vegetation and moss regrowth beneath the body which suggests deposition in open water. Moss samples dating to 1-400CE correspond to a period of heavy cultivation. The initial findings were published in the Danish journal $K U M L$ as well as a general summary authored by Glob, a report of the fingerprint investigations by Andersen and the conservation methods

\footnotetext{
${ }^{23}$ Niels Lynnerup, "Medical Imaging of Mummies and Bog Bodies-A Mini-Review," Gerontology 56 (2010): 444-7, Aldhouse-Green, Bog Bodies Uncovered, 68.

24 Taphonomy: the process of fossilization and the forces in the depositional matrix which act upon an interred object. For example, the immense pressure applied by the weight of the bog. Lynnerup "Medical Imaging," 444-7, "The Latest News About Tollund Man" Silkeborg Museum, accessed June 31, 2019, http://www.museumsilkeborg.dk/the-latest-news-about-tollund-man, P. Charlier et al., "Plantar Warts on Tollund Man's Feet (Denmark $4^{\text {th }}$ Century BC). Limits of Retrospective Dermatological Diagnosis," Clinical and Experimental Dermatology 42 (2017): 547-8.
} 
by Lange-Kornbak. ${ }^{25}$ Radiological investigations were performed in 1952 and 1956. In May 1952 at Aarhus District General Hospital Professor Carl Krebs and Dr. Erling Ratjen identified an assumed pre-mortem cranial fracture located in the right vertex-temple region caused by a blunt instrument. They discovered a remarkably well preserved albeit shrunken brain and an oblique fracture of the left tibia $10.5 \mathrm{~cm}$ below the knee, exposing the bone and likely resulting from a fall pre-mortem. They also observed signs of incipient rheumatoid arthritis of the thoracic vertebrae, rarely seen prior to 30 years of age. The post-mortem was performed by Dr. Munck, who removed the gut, stomach, liver and one identifiable testicle with no signs of illness or evidence of disease. He appeared to be a healthy 30 -year-old man. ${ }^{26}$

\section{The Throat Laceration}

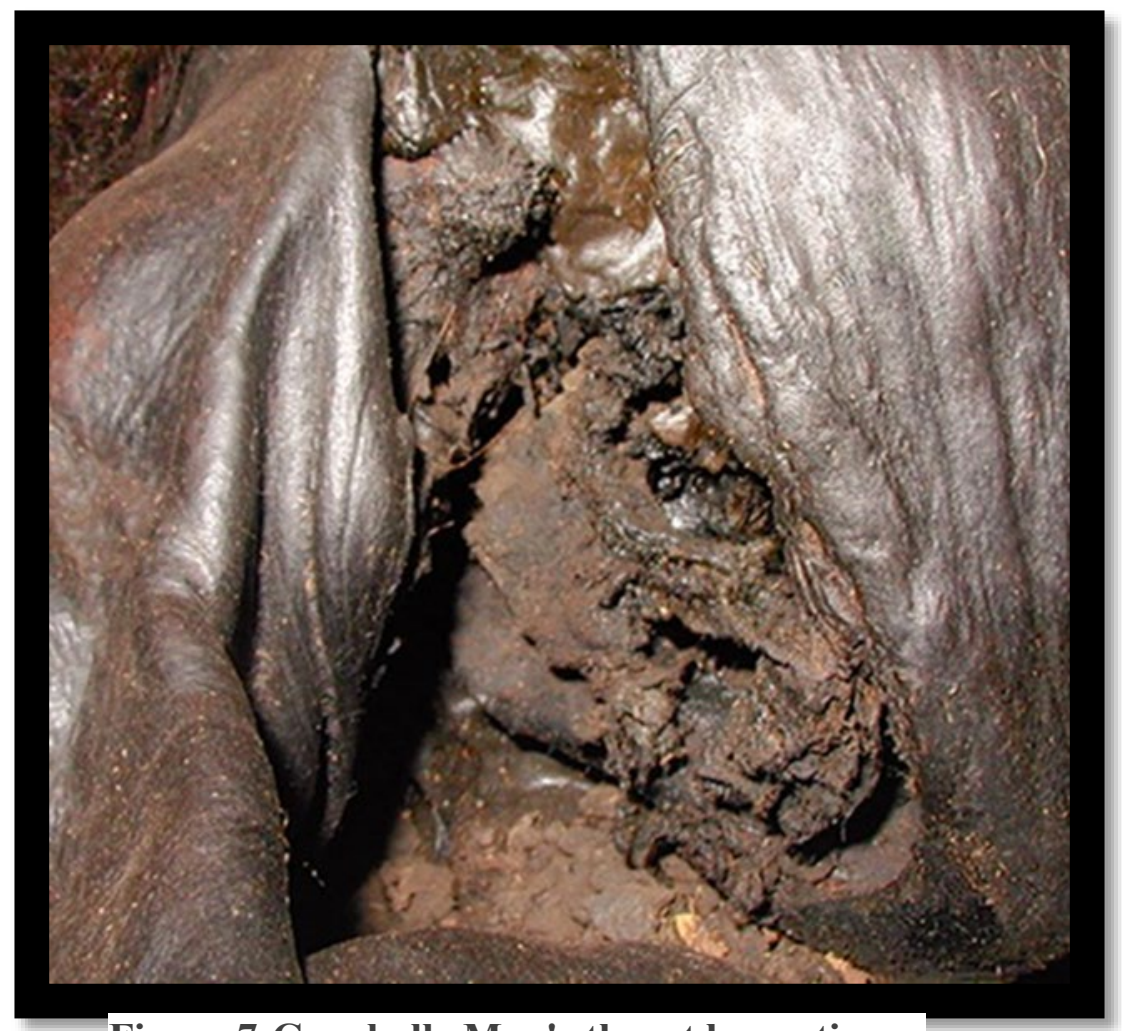

Figure 7-Grauballe Man's throat laceration.

Photo Museum Moesgaard, viewed 25 August 2020.

https://www.moesgaardmuseum.dk/media/4735/18 $07 \quad 30$ 844.jpg
Munck concluded the throat laceration was executed by a secondary person due to direction, excluding the possibility of suicide. He detailed the gash as beginning behind the right ear, running upwards along the edge of the mandible behind the tip of the chin. The shrunken skin pulls downwards revealing a large opening into the mouth, exposing the tongue, larynx and a severed epiglottis, hyoid bone, pharynx,

\footnotetext{
${ }^{25}$ Gill-Robinson, The Iron Age Bog Bodies, 54, Asingh, "The man in the bog," 14, 17-19, 25-6, 28-9, Glob, The Bog People, 56-7.

${ }^{26}$ Gregersen et al., "Forensic Evidence," 234, 236-7, 240-1, 244, 246-8, 252, 254, 256-8, Asingh, "The man in the bog," 25-6, 28-9, Aldhouse-Green, Bog Bodies Uncovered,72, Glob, The Bog People, 45, 48-9.
} 
esophagus and both the jugular vein and carotid arteries. Extending to the spine, it presumably struck the foremost ligament. It was initially assumed to be several cuts but has since been observed as one cut produced in a swift left-right movement with some subsidiary cuts from jerking. Death resulted within a few minutes from simultaneous blood loss to the brain and suction into the respiratory system. ${ }^{27}$

\section{Teeth}

21 teeth were found preserved in the oral cavity and were examined by Holger Friss and Egil Warrer. 12 remained in situ: seven in the maxilla, five in the mandible. They showed signs of heavy wear, harris lines (indicating stunted childhood development), periodontitis, inflammation (indicating antemortem trauma), and caries lesions. They were subsequently extracted, stored in glass containers in distilled water and radiographed. Unfortunately, the teeth, sent to the Royal Dental College, were mislaid but upon rediscovery in 1963 were returned to the Prehistoric Museum of Aarhus in a desiccated state, shrunken by $30 \%{ }^{28}$

\section{Stomach Contents}

The gut contained thick brown sludge which was preserved in a mixture of $50-70 \%$ ethanol and glacial acetic acid and 40\% formaldehyde. Brown sludge from the alimentary tract was analyzed by Archaeobotanist Hans Helbaek. With a volume of $610 \mathrm{ml}$ (twice as much as Tollund's 270ml), it resembled gruel containing 66 different species of weeds, grasses and a small amount of animal bones including the chaff of hulled barley, black bindweed, soft brome, wheat, oat, fat hen, corn spurrey, sheep's sorrel, perennial rye-grass, Yorkshire fog, ribwort plantain, fungal hypae, spores, sporangia, eggs of whipworm, pebbles and quartz sand. Notable ingredients include Rye (a new crop during the Iron Age which coincided with great changes in the societal structure driven by agrarian technological advances), chaff (typically mixed with cereals during famine although its presence in eight other bodies suggests more indifference in proper processing), and lastly ergot, a parasite to wild grasses with hallucinogenic effects. Despite Helbaek's conclusion that the unspecific "quantity" of ergot present reflected typical consumption, researchers speculatively attributed its presence

\footnotetext{
${ }^{27}$ Aldhouse-Green, Bog Bodies Uncovered, 116-8, Gregersen et al., "Forensic Evidence," 234, 240-1, 244, 246$8,252,254,256-8$.

${ }^{28}$ Strehle, "Conservation," 37, 42-5, Dorthe Ahrenholt-Bindslev et al., "Grauballe Man's Teeth and Jaws," in Grauballe Man: An Iron Age Bog Body Revisited, eds. Pauline Asingh, Niels Lynnerup (Jutland: Narayana Press, 2007), 141, Glob, The Bog People, 56-7, Aldhouse-Green, Bog Bodies Uncovered, 58.
} 
to a psychedelic meal intended to inflict pain, poison or induce ritualistic behavior. These ingredients are principally by-products of cereal processing, fairly nutritional but rather unpalatable. The absence of fruit indicates consumption in winter for lack of availability. Aldhouse-Green asserts the diversity of plant species represents intentional gathering from a variety of landscapes to reflect a specially prepared ritual meal which served as a form of deliberate humiliation or degradation. These analyses were revisited and re-examined in a thorough undertaking in 2001-2. ${ }^{29}$

\section{Re-examination of Initial Analyses}

In 2001-2 a team led by scholars Asingh and Lynnerup conducted a re-examination of the original investigations to clarify pathology and determine preservation impacts of prior conservation treatments, with the aim of documenting and preserving the body for future posterity. Conducting minimally invasive investigations including radiography, CT and MRI scans, Infrared reflectography, 3D visualization and stereolithography, they reviewed Grauballe Man's age, health and diet. This information was subsequently utilized to construct a new exhibit. ${ }^{30} \mathrm{~A}$ facial reconstruction was produced by Caroline Wilkinson, although it proved rather challenging due to skeletal deformation. This was achieved through stereolithographic reconstruction formulated from CT scans. Data from a population of 4049-year-old European men were used for reference. Facial reconstructions have significant implications in our own perception by normalizing proportions, compensating for distortion and visualizing a realistic face that allows the public to engage with Grauballe Man's humanity on an interpersonal level. ${ }^{31}$

\footnotetext{
${ }^{29}$ Skoglund, "Diet," 153, Aldhouse-Green, Bog Bodies Uncovered, 58-60, Jody Joy, Lindow Man (London: The British Museum Press, 2009), 31, Jan Andreas Harild et al., "New Analyses of Grauballe Man's Gut Contents" in Grauballe Man: An Iron Age Bog Body Revisited, eds. Pauline Asingh, Niels Lynnerup (Jutland: Narayana Press, 2007), 155, 158-161, 165, 174-6, 180-1, Asingh, "The man in the bog," 26.

${ }^{30}$ Aldhouse-Green, Bog Bodies Uncovered, 70-1, Asingh, "The man in the bog," 31.

${ }^{31}$ Caroline Wilkinson. "Facial Reconstruction of Grauballe Man," in Grauballe Man: An Iron Age Bog Body Revisited, eds. Pauline Asingh, Niels Lynnerup (Jutland: Narayana Press, 2007), 260-1, 265, 271, AldhouseGreen, Bog Bodies Uncovered, 80.
} 


\section{State of Preservation}

The task was undertaken to observe the impact of previous conservation treatment to understand his current preservation. Original records proved rather vague thus investigation was required to plug documentation holes. Unaware of which locations had been stuffed with filler or applied with sealant, Lynnerup and Asingh employed UV to expose resin varnishing and wax fillings used to remodel facial features and the lower back. Fortunately, no microorganisms were present in the fillings. Despite the general destructiveness of glycerine and cod liver oil, the dermal layers remained stable. Four 8-19mg skin samples were extracted from the margins of the 1952 autopsy incision and subjected to hydrothermal stability, indicating a medium state of degradation. ${ }^{32}$

\section{Aging}

A fully ossified sternum suggested an age of at least 25-30 years. Bone samples from the iliac crest were micro CT scanned, obtaining an age estimate by counting the mean number of double lamellae multiplied by thickness $(6.4 \mathrm{~mm})$, of 34 -years-old. ${ }^{33}$

\section{Teeth}

The dental examinations were also revisited. 19 teeth and two roots were subjected to scanning electron microscopy (SEM) and individual radiographs. The absent enamel, and exposed dentine which indicated a coarse diet, made DNA extraction nearly impossible and analyses inconclusive. The right lower incisor was lost antemortem and the first molar suffered a major caries cavity. At the time of death there was a major, likely painful inflammation on the left posterior of the maxilla. ${ }^{34}$

\footnotetext{
${ }^{32}$ Lynnerup, "Methods," 364, Frederiksen, Glastrup. "Conservation and Analysis," 68, 70-2, 74, Mogens S. Koch, Mikkel Scharff. "Infared Reflectography (IRr) Surface Analysis." in Grauballe Man: An Iron Age Bog Body Revisited, eds. Pauline Asingh, Niels Lynnerup (Jutland: Narayana Press, 2007),79, Rene Larsen, Dorte Vestergaard Poulsen. "Analysis of the Skin." in Grauballe Man: An Iron Age Bog Body Revisited, eds. Pauline Asingh, Niels Lynnerup (Jutland: Narayana Press, 2007), 85, 89.

${ }^{33}$ Lene Warner Boel, Michel Dalstra. "Microscopical Analyses of Bone Specimens; Structural Changes Related to Chronological Age and Possible Diseases," in Grauballe Man: An Iron Age Bog Body Revisited, eds. Pauline Asingh, Niels Lynnerup (Jutland: Narayana Press, 2007), 121-2, 139.

${ }^{34}$ Lynnerup, "Bog Bodies," 1010, Ahrenholt-Bindslev et al., "Grauballe Man's Teeth and Jaws,"142, 145-6, $148,151$.
} 


\section{Stomach Contents and Diet Reconstruction}

Revisional analyses of the last meal revealed with 95\% confidence 334-754 sclerotia of ergot hosted by Yorkshire fog which lies within the upper limits of the EU's current guidelines of safe consumption, squashing any ritualization speculation. Hair fibre analysis was undertaken at Bradford University. As hair is not remodeled post-keratinization and grows at a relatively constant rate $(1 \mathrm{~cm}$ per month), it provides an ideal archive of lifeways information although alteration within the depositional environment may be deceptive. The external surface was examined by SEM, internal light and transmission electron microscopy for bacterial degradation of original lipid composition. A good overall retention of structural morphology was observed. Furthermore, isotope ratio mass spectrometry was used to explore short term and seasonal variation in subsistence. The $\mathrm{D}^{13} \mathrm{C}$ values were consistent with terrestrial subsistence, coinciding with the $\mathrm{D}^{15} \mathrm{~N}$ values of meat and dairy. A stable diet of predominately animal protein was reflected, with little variation. ${ }^{35}$

\section{Dating}

In 1952 flattened lungs and the liver were used for radiocarbon dating but proved insufficient. In 1979 Henrik Tauber at the Copenhagen Laboratory utilized muscle and stomach tissue treated with sodium hydroxide to receive a considerably older date of 110BCE-50CE. In 1996 two hair samples produced a date of 400-200BCE. Most recently Gregersen et al. performed AMS dating on the pelvis and some plant root samples extracted from the gut. The pelvic sample appeared younger (150BCE-30CE) due to the oak bark conservation treatment. The plant roots exhibited structurally homogenous tissue without pathology and were identified as sedge, which obtains carbon from atmospheric $\mathrm{CO}^{2}$ rather than dissolved bicarbonate. In the acidic bog environment bicarbonate concentration is negligible, ruling out the uptake of fossil soil carbon, thus negating an excessive $\mathrm{C}^{14}$ age. The roots externally penetrated the body and did not originate as seeds inside the gut. Asingh assumes a date of for the body of 400-200BCE and the roots of 490-230BCE. This places him within the preRoman Iron Age, notably a time of high carbon dioxide fluctuation and changing climate. ${ }^{36}$

\footnotetext{
${ }^{35}$ Andreas Harild et al., "New Analyses," 174-6, Andrew Wilson et al., "Information on Grauballe Man from his Hair," in Grauballe Man: An Iron Age Bog Body Revisited, eds. Pauline Asingh, Niels Lynnerup (Jutland: Narayana Press, 2007), 188-90, 192, 194-5, Aldhouse-Green, Bog Bodies Uncovered, 59-60.

${ }^{36}$ Shanti Menon, "The People of the Bog," Discover, August, 1997, 66, Stodkilde-Jorgensen et al., "The Intestines," 531-2, 534, Jan Heinemeir, Pauline Asingh. "Dating of Grauballe Man," in Grauballe Man: An Iron Age Bog Body Revisited, eds. Pauline Asingh, Niels Lynnerup (Jutland: Narayana Press, 2007), 196-7, 199-201.
} 


\section{Paleopathology}

Radiological exams were combined with 3D reconstructions utilizing shaded surface display (SSD) and volume rendering (VR) to create valuable imaging of musco-skeletal structures. It proved challenging to visualize mineralized tissues as the bones were strongly decalcified and radiolucent (less dense) due to diagenetic leaching of minerals, but dense skin and tendons were clearly visualized due to iron salt. Lynnerup et al. warn this may lead to erroneous interpretations. They reiterated the 1952/56 findings of an overall well-preserved skeleton except for a left elbow dislocation from a dissolved joint capsule, slightly degenerative spine indicated by new bone formation and dislocation of both sternoclavicular joints, but otherwise normal vertebrae and clavicles. An endoscopy inserted into the thoracic cavity identified the diaphragm, and into the neck wound revealing the larynx and trachea intact. The neck laceration extended to the cervical vertebrae, which exhibited minor post-mortem dislocations. There were several post-mortem fractured ribs. Segmentation of the craniofacial skeleton allowed possible reconstruction and a stereolithographic model revealed a cranial vault collapse consistent with post-mortem damage, likely taphonomic. ${ }^{37}$ This implicates interpretational narratives, particularly those which cite extreme violence or 'overkill'. Aldhouse-Green subscribes to the overkill narrative, stating the kill was intentionally controlled with intent to cause maximum harm. She believes it was possibly a demonstration of a theatrical blood killing wherein a fountain of spurting blood served as a pollutant or purifier. This involved crossing internal and external corporeal boundaries as the liminal membrane is breached and the confines of the body lose their integrity. Furthermore, she argues the tibia fracture was intended as torture, to inflict pain, disable and prevent escape. ${ }^{38}$ However, Lynnerup emphasizes the contention that several of these traumas are the result of post-mortem diagenesis effects, not the result of deliberate violence. He further asserts the interpretation of blunt force trauma to the leg and head, previously ascribed to unnecessary

\footnotetext{
${ }^{37}$ Anne Grethe Jurik. "New Radiological Examinations," in Grauballe Man: An Iron Age Bog Body Revisited, eds. Pauline Asingh, Niels Lynnerup (Jutland: Narayana Press, 2007), 95, 97-99, 101, 106, Niels Lynnerup et al., "CT-scanning, 3D Visualisations and Stereolithography" in Grauballe Man: An Iron Age Bog Body Revisited, eds. Pauline Asingh, Niels Lynnerup (Jutland: Narayana Press, 2007), 111, 113-4, 117-121, 122-3, Aksel Kruse, "Endoscopic Examination of Grauballe Man," in Grauballe Man: An Iron Age Bog Body Revisited, eds. Pauline Asingh, Niels Lynnerup (Jutland: Narayana Press, 2007), 125-6, 129.

${ }^{38}$ Aldhouse-Green, Bog Bodies Uncovered, 116-8, 121.
} 
overkill as part of a sacrificial rite needs to be revised. It may not have been as violent as previously assumed. ${ }^{39}$

\section{Interpretational Narratives}

\section{Glob and the Birth of Modern Archaeological Interpretation}

Promptly following their discovery Tollund and Grauballe Men became superstars as Glob's poetic accounts played a large role in their exceptional afterlife in art, literature and social consciousness. Despite some previous common knowledge, Glob's publication of The Bog People in 1965 introduced the first detailed knowledge of bog bodies into popular culture. His strenuous sacrifice interpretation relies on a curious mixture of empirical evidence, archaeological finds and Tacitus, who paints a vivid picture of the fertility rites to the earth goddess Nerthus. He begins his sensational narrative with overwhelming sweeping generalizations of young and old, men and women victims suffering mutilation, torture and dismemberment, killed by decapitation, strangulation, hanging and drowning; all exhibit a pattern of homogenous extreme violence. Then seemingly contradicting himself, he iterates them not as one uniformed phenomenon, but driven by changing religious beliefs intertwined with ideas of death and law reflected in burial custom. He observes a shift in the late Roman Iron Age to a more materialistic concept of death and an apparent belief in a kingdom of the dead, further noting their deviance from typical burials. He conceives of a symbolic association between bog bodies and other sacrificial offerings connected with marsh and water, inferring they were offered to the same powers. Grauballe Man's throat laceration for example exhibits similar characteristics to a sacrificial victim's blood poured out to the gods. The crime which sealed his fate and to be appeased with his life; arousing the gods' anger. These powers Glob delegated to the Celtic Iron Age mother goddess Nerthus whom he picked from the pages of Tacitus' Germania (Tac. Ger, 40.2-41), the only description in existence on the supposed goddess and her cult. Worshipped apparently as early as the Neolithic, evidence of her cult includes torcs and necklaces deposited in bogs. Their impracticality for normal usage suggests they were highly esteemed as offerings for

${ }^{39}$ Lynnerup, "Bog Bodies," 1010. 
childbirth or conception. He attributed the garrotte around Tollund Man's neck to the same cultic expression as the torcs and neck rings. Glob contextualizes these artifacts within the fertility rite of the sacred spring wedding which symbolized the union between earth and sky. He links Tacitus' description of the drowning of slave attendants in the lake to the watery and dangerous mystical symbolism embodied by the bog. He argues both Tollund and Grauballe Men briefly assumed the role of husband to Nerthus during the spring feasts and were consummated by death to her to ensure communal fertility. ${ }^{40}$ The narrative of Danish national romanticism as descendants of a noble tradition in sacrificing to the goddess of love highly appealed to Dane's social consciousness during the post-war years. Grauballe and Tollund Men provided a picture not of warlike primitivism, but of sacrificial love which reconciled a death beautiful and pure. They came to represent common identity through Glob, the charismatic, animated storyteller. His exciting ideas invited the public to play a crucial role in the rebirth of these national treasures. ${ }^{41}$

\section{Glob’s Influence in Modern Scholarship}

Glob's narratives of excessive violence and human sacrifice to Nerthus remain pervasive in modern scholarship and are pursued by Aldhouse-Green and Giles. They perform a thoughtprovoking dissection of sacrifice from a spiritual perspective as an alternative experience of death, deeper than purely ritualistic notions. Green displays wariness of sacrificial interpretations, but also reluctance in dismissing them entirely while Chapman and Gearey argue in contrast to the idea of overkill, that the executions may have been humane. All scholars acknowledge there is no universal interpretation, yet pervasive sweeping generalizations serve to homogenize and undermine spatial-temporal diversity and hence become counterproductive.

\footnotetext{
${ }^{40}$ Glob, The Bog People, 144-7, 152, 156, 159, 162-6, 190-2, Jarret Lobell, Samir Patel, "Bog Bodies Rediscovered," Archaeology 63, no. 3 (2010):23, Purdy, "Unearthing the Past," 446, Gill-Robinson, The Iron Age Bog Bodies, 71-2.

${ }^{41}$ Asingh, Grauballe Man, 18, 24-6.
} 


\section{Mysticism of the Bog}

For Aldhouse-Green cultural context is paramount. North-western Europe in the Iron Age was inhabited by large rural communities founded upon farming, manufacture, metalwork and the pottery and jewelry trade, driving a highly stratified society with high ranking individuals. Persistent usage of bogs indicates full awareness of their extraordinary preservative properties due to which they were regarded with reverence and fear. She believes the inhuman transformation to leathered skin and red-dyed hair, later the color of chthonic deities, represented an otherworldly claim over the bodies. The uncultivatable nature set bogs apart and imbued them with a sanctity to be respected and placated. Perhaps they represented the seat of disease; fitting places for the inexcusable dead. A distinct lack of grave goods and signs of abuse infer low ranking. In agreement with Glob, she interprets them as thank offerings to the bog which provided iron, fuel and food preservation. Offerings took the form of human sacrifices either to ensure good harvests or for the celebration of military victories, as punishment for crimes or as social selection against individuals with physical imperfections, although the distinction between judicial and sacerdotal execution is tenuous. They were imbued with undercurrents of deliberate humiliation, violence and the denial of identity wherein ritualistic atonement served to neutralize pollution. She argues the marks of restraint, nakedness and denial of grave goods symbolically reduce the victim to serfdom. ${ }^{42}$

\section{The Metaphysics of Sacrifice}

Green dissects the practice of human sacrifice as destruction or removal from the earthly realm to achieve a positive or avert a negative outcome, with notions of giving on one hand and separation on the other. This may incorporate requests to spirits, be a response to a crisis, or a thank-offering for a successful harvest, childbirth, recovery from illness or satisfactory business. Separation is an important efficacy as it signifies holiness. The distance between the sacred and profane is bridged by offerings. Successful transference of the gift necessitates a physical or metaphorical removal from the earthly world to the spirit, hence the act of immersion in water, i.e.-enclosure within a sanctified space. The act of killing is equivalent to the destruction of a votive offering and Green argues that violence plays an essential role in

\footnotetext{
42 Aldhouse-Green, Bog Bodies Uncovered, 35-8, 45, 49, 53, 82-3, 90, 92, 145, 197, Jarcho, "Tollund Man and Other Bog Burials," 556-7, Bahn, "Through Nature to Eternity," 62, 67.
} 
the potency of the sacrificial gift. Ritual aggression was an important element in the symbolism of sacrifice as the energy associated with violence stimulated regeneration and prosperity. In penetrative death spillage was central to the symbolism associated with ritual as blood held symbolic properties. She translates somewhat liberally Grauballe Man's supposed expression of pain and terror as his preserved lack of consent. She also acknowledges a lack of sufficient evidence to constitute sacrificial activity. ${ }^{43}$

\section{Ritual Performance}

Giles extrapolates the ritualism of the killings as ideological theatrical performances surrounding difficult deaths to express and negotiate trauma. Her performance theory is developed in relation to contexts of violence, embodying the necessary tension of articulating pain while resolving a worldly resolution. Alternatively, performances may serve to re-injure in a "shattering effect" rather than seek resolution. ${ }^{44}$ These rites were callous and likely framed within a different ontological understanding of corporeal violence which was intertwined with concepts of honor and renown earned in death. Traumatic death posed a particular threat and potentially jeopardized communal continuity. Ceremonies acknowledged the destructive forces present as a means of confronting and enduring future repetition. ${ }^{45}$ Although archaeologists are extremely wary of interpreting execution as human sacrifice owing to the ambiguous nature of empirical evidence, Green cautions it unwise to entirely dismiss the potential for sacrifice. From a $21^{\text {st }}$-century viewpoint animate and inanimate value is graded according to strict anthropocentric rules which consider humans of greater value. Thus, she cautions against imposing modern assumptions onto the past. The idea of human sacrifice is uncomfortable in scholarship and unaccepted in modern society. Therefore, it is necessary to question whether there is a natural assumption concerning ancient priorities. There is no justification to mistrust all allusions yet by the paucity of evidence it was not a normative rite. ${ }^{46}$

\footnotetext{
${ }^{43}$ Miranda Green, "Humans as Ritual Victims in the Later Prehistory of Western Europe," Oxford Journal of Archaeology 17, no.2 (1998): 169-70, 173, 176-7, 179-80.

${ }^{44}$ Melanie Giles, "Performing Pain, Performing Beauty: Dealing with Difficult Death in the Iron Age," Cambridge Archaeological Journal 25, no.3 (July, 2014): 539-40.

${ }^{45}$ Giles, "Performing Pain," 547-8.

${ }^{46}$ Green, "Humans as Ritual Victims,"170-2, 174.
} 


\section{The Notion of Overkill?}

Furthermore, Gill-Robinson and Chapman and Gearey question extreme excess of violence. Chapman and Gearey expose the complete lack of prior consideration toward an individualistic bodily experience of pain. Pain may be measured through phenomenological principles, allowing consideration of its significance within individual suffering up to the point of death. This is relevant for our understanding and interpretation of the role of pain infliction and tolerance in the performative nature of ritual. It allows us to consider the duration of events and adopt a chronological focus. They use consciousness as a quantitative proxy to examine each injury in relation to the level and duration of pain. In the example of Tollund Man and the instance of asphyxia, loss of consciousness likely followed after 13 seconds, convulsions after 15 seconds and complete cessation of respiration after two minutes. In the example of Grauballe Man and the instance of a throat laceration, dizziness, confusion and a rapid drop in blood pressure would have resulted after two liters of blood loss, causing loss of consciousness within 10 seconds and death within two-three minutes. They conclude that the experience of pain was not prolonged and unconsciousness was swift, shortening suffering and equating to a rapid culmination of the event. Extended infliction was not a deliberate feature and execution was likely designed to minimize, not maximize the duration of pain. ${ }^{47}$ Gill-Robinson likewise asserts violent deaths have been vastly overstated, with a lack of sufficient data and inadequate evidence for ritualism. ${ }^{48}$ However, a humane execution does not necessarily negate brutality. The hysteria surrounding the notion of overkill and ritualistic killing seems to ignore the brutality of non-ritualistic killing. Thus, ritual narratives may over-determine these deaths as metaphysical or even positive acts which allow their killers to be perceived as something other than murderers. This may cultivate a cultural relativity whereby ritual killings are not permitted to be judged by modern standards concerning violence, brutality and the value of human life. It remains unknown how many died violent deaths and how many did not. Greater clarity into these percentages would enable further revisional work regarding sensationalist overkill narratives and exploration into how much revision would be needed. There is a current uncertainty regarding how violent non-ritual deaths may implicate our assessments into the nature of these societies.

\footnotetext{
${ }^{47}$ Henry Chapman, Benjamin Gearey, "Towards an Archaeology of Pain? Assessing the Evidence from Later Prehistoric Bog Bodies," Oxford Journal of Archaeology 38, no. 2 (2019): 214-5, 219-24.

${ }^{48}$ Gill-Robinson, The Iron Age Bog Bodies, 357-9.
} 
All scholars agree there is no single explanation but there is a combination of diverse possibilities. Each example must be interpreted on a case-by-case basis employing archaeological, environmental and cultural evidence in a holistic approach. However, reluctance to admit the presence of sacrifice should be tempered by the acknowledgment that within hierarchical societies human life was not inevitably inviolate, therefore sacrifice should not be ruled out. ${ }^{49}$ While this is valid, sweeping generalized interpretations seem counterproductive and counterintuitive to the universal acknowledgment for individual interpretation. They present the temptation to universally apply hypothetical theories while ignoring empirical evidence and individualistic pathology, hence the author's inclusion of case studies. Realistically, interpretative questions remain unanswerable on account of the innate restriction of empirical evidence combined with a lack of literary evidence. This is particularly evident in the case of Lindow Man, as explored in the following chapter.

${ }^{49}$ Green, "Humans as Ritual Victims,"186, Bahn, “Through Nature to Eternity," 62, 67. 


\section{Lindow Man: Archaeological Narratives and Modern Identity}

\section{Introduction}

Lindow Man, Britain's most famous bog body, was discovered in Lindow Moss, Cheshire, Manchester in 1984 and has remained ever since arguably the most sensational and investigated find of Prehistoric Britain. He appeared to have suffered two blows to the head, a slashed jugular vein, one rib and two cervical vertebrae fractures and a garrotte was hung around his neck. His significance lies in the unique nature of violence he seems to represent from the past which has led to particularly sensationalized and mystically dramatized interpretations of ritualistic human sacrifice. Discussion surrounding Lindow Man above all remains controversial. He has also been the subject of Manchester Museum's experimental exhibition 'Lindow Man: A Bog Body Mystery' which provoked further controversy over who has the authority to voice the past and who the past belongs to. This chapter seeks to ascertain the importance of archaeological narratives in formulating modern identity and the way they are presented to and received by the public. Analyses performed upon Lindow Man include investigation into the extent of his injuries, analysis of stomach contents and paleoenvironmental reconstruction. His dating has been hotly contended due to contamination and vast deviation between labs, implicating the events surrounding his death. In the absence of empirical evidence, scholars Aldhouse-Green, Giles and Ross have relied upon textual accounts to provide the socio-political context within which to conceptualize acts of extreme violence. They argue an orthodox interpretation of Lindow Man as a Celtic druid sacrificed possibly as a response to the tension of the enclaving $1^{\text {st }}$ century CE Roman Invasion. In opposition, Hutton and Connolly assert that traditional approaches characterize the ancients as savages which acts to peripheralize them and exaggerate a brutality associated with their "otherness." Seamus Heaney also made this connection in his analogy of the bog victims with the Troubles' casualties in the late $20^{\text {th }}$ century, which will be further explored in the last chapter. Hutton argues that traditional interpretations conditionally rest upon dubious dating and extrapolated forensics based upon a pre-established scholarly foundation of Glob and the 
Danish bog bodies. These narratives become highly significant and potentially problematic when presented through media and museums lacking diverse perspectives. In exception to this, the Manchester Museum's 2008 exhibition of Lindow Man encompassed the diverse voices of forensic scientists, archaeologists, modern druids, peat cutters and locals as well as a comprehensive public feedback system to provoke debate and promote cross-cultural understanding for a more sustainable world. Their progressive approaches attracted conservative criticisms in the form of a lack of authority perceived as lazy, self-indulgent and a devaluation of curatorial expertise. The case of Lindow Man evidently demonstrates that archaeological narratives hugely underpin the formation of modern identity. 


\section{The Discovery of Lindow Man}

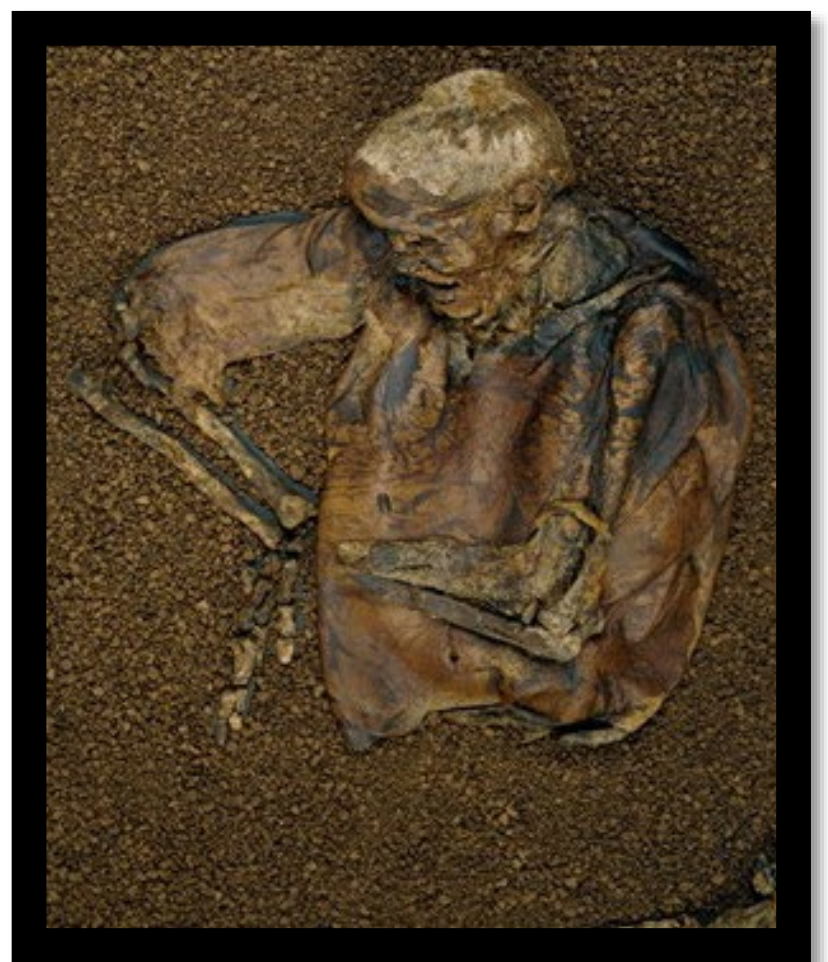

Figure 8: Torso and Head of Lindow Man.

(C) The Trustees of the British Museum. Shared under a Creative Commons

Attribution-NonCommercial-ShareAlike 4.0 International (CC BY-NC-SA

4.0) licence, viewed 12 August 2020,

$<$.https://www.britishmuseum.org/collection/image/126565003>

On the first of August 1984 a peat cutter pulled an unidentified object off a conveyor belt, noticing a further protruding flap in the bog. The object was identified as a human leg, raising suspicion as police at the time were investigating a local murder. The head, neck and upper torso were discovered still in the moss. No artifacts were found in his vicinity. Lindow Man was exhumed and transported to Macclesfield District Hospital's mortuary where dating proved his 2000-year heritage, halting the police investigation and cementing his fame in British History. He was endearingly dubbed "Pete Marsh" by the media, speaking to his strong local connection. However, he was neither alone nor the first bog body in Britain, taking his place as just one of 106 bodies recorded in England and Wales and 35 in Scotland and with $96 \%$ of British bogs consumed since 1850, he may well be the last. The uncovering 
of the body took five days and was filmed and aired on the BBC in 1985 to 10 million viewers. ${ }^{50}$

\section{State of Health}

Lindow Man proved to be a $1.65 \mathrm{~m}$ tall healthy, well-built man in his mid-20s with 'manicured' nails, who appeared to have eaten the last meal of a burnt pancake washed down with a drink of mistletoe. His stomach contained evidence of whip and roundworms and the pollen of wheat and barley. His sideburns, mustache, hair and beard are clearly preserved, dyed red by the neutral $\mathrm{pH}$ of the bog. He too was deposited stark naked excepting a fox-fur armband embellishing his upper left arm. 30 heavily worn teeth were discovered inside the mouth with the enamel entirely dissolved thereby rendering caries frequency undeterminable. The significance of Lindow Man lies in the imaginative reconstruction of British prehistory. He exposes the limitations of scientific knowledge in how little is known about prehistoric people despite our strong connection with them. ${ }^{51}$

\section{Scientific Analyses}

Scientific investigation is essential in archaeology for empirical-based analyses and evidencebased theory. Methods of investigation carried out on Lindow Man include magnetic resonance imaging, 3D visualizations and facial reconstruction, xeroradiography, computer tomography and minimally invasive procedures such as endoscopy. There has also been some focus on the depositional locus, such as paleo-environmental reconstruction but this remains under-researched.

\section{Conservation}

From 1985-6 he was freeze-dried in 100-200 millitorr, the most common method in treating waterlogged wood. In order to test the suitability of this treatment comparative experiments

\footnotetext{
${ }^{50}$ Parker-Pearson, "Lindow Man," 15-16, Ronald Hutton, "Why does Lindow Man Matter?" Time and Mind 4, no. 2 (2011): 135-6, Joy, Lindow Man, 5-7, 21, Eamonn Kelly, "Secrets of the Bog Bodies: The Enigma of the Iron Age Explained," Archaeology Ireland 20, no. 1 (2006): 26-9.

${ }^{51}$ Hutton, "Why does Lindow Man Matter?"135-6, Joy, Lindow Man, 12, Lobell, Patel, "Bog Bodies Rediscovered," 22, Connolly, "Lindow Man: Britain's Prehistoric Bog Body," Anthropology Today 1, no. 5 (1985): 15 .
} 
were conducted on pig skin which was freeze-dried for four weeks, resulting in a shrinkage of less than 5\%. The same experiment was conducted with air drying which displayed a 50\% shrinkage. He was soaked in an immersion bath of $15 \%$ polyethylene glycol (PEG) and 400 distilled water for four weeks. He was then wrapped in plastic wrap and frozen at -28degrees. Not unexpectedly there resulted some lightening of the skin. ${ }^{52}$

Age

Under 1000x magnification facial hair notches trimmed with shears were observed along with his smooth nails. Femur and humerus length suggested a slightly taller than average height and a weight of 10 stone, while a recently fused clavicle indicated an age of around 25 years. $^{53}$

\section{Paleopathology}

His contested pathologies include lacerations of a $3.5 \mathrm{~cm}$ long ' $\mathrm{V}$ ' shape on the top of his head and back of his scalp with fragments of his skull embedded in his brain, possibly executed by a narrow blunt-edged weapon such as an ax. Swelling along the wound margins, indicating bruising, signifies he remained alive for some hours after. The garrotte left ligature marks on the neck. There is a clean cut, possibly a stab wound along the right clavicle $3 \mathrm{~cm}$ in length. The 8-9 $9^{\text {th }}$ posterior ribs have been fractured and the neck broken. At Middlesex and St Bartholomew's hospitals he was subjected to x-rays and CT scans. Bones, as previously noted, are often poorly visualized and patchy appearances may lead to misdiagnoses of pseudo-pathology. This leads Lynnerup to believe the skull fracture is likely a result of the taphonomic processes from the crushing weight of the bog combined with the pliability of Lindow Man's bones rather than blunt force trauma. ${ }^{54}$ A 3D image revealed the extent of damage regarding the skull fractures and broken vertebrae. Magnetic imaging was used to produce an image of the brain. From the CT scans Richard Neave produced a high-resolution 3D printed facial reconstruction for exhibition. An Endoscopy explored the mouth, throat, chest and head, revealing a reduced tongue and loose teeth as a result of decayed ligaments and a partially eroded mandible. Spine herniations ("Smorl's nodes") indicate mild arthritis in

\footnotetext{
52 Joy, Lindow Man, 36-7.

${ }^{53}$ Lynnerup, "Methods," 163, 360-1, 371, Lynnerup, "Bog Bodies," 1008-10, Keys, "Europe's First Mummies," 341, Joy, Lindow Man, 7, 23-7.

${ }^{54}$ Lynnerup, "Bog Bodies," 1008-10.
} 
the lower spine, representing minor stress and developmental problems. On his back what was initially believed to be smallpox scars were revealed as post-mortem decay of the epidermis. No major organs were found except the stomach. ${ }^{55}$

\section{Stomach Contents}

Pollen analysis of the stomach contents revealed wheat that had been heated to 200-250 degrees Celsius (leading to speculation of an unleavened griddlecake cooked on an open fire) and 4 grains of mistletoe pollen, possibly ingested inadvertently. Eggs of whip and maw worm were discovered in the intestinal tract, possibly associated with symptoms of diarrhea, minor discomfort and nausea. ${ }^{56}$

\section{Paleo-environmental reconstruction}

The exploration of the body's spatial positioning within its contemporary landscape improves our understanding of the cultural context surrounding Lindow Man's death and the motives surrounding his deposition. This enriches and expands our interpretational abilities. ${ }^{57}$ Primarily research has concentrated on forensic analyses rather than wider consideration of environmental context. Environmental research is lacking and is biased toward the findspot rather than the wider environment. It is crucial to obtain quality paleo-environmental data in order to reconstruct the spatial and temporal variability of the bog over time. The wetness likely made it difficult or impossible to traverse lacking trackways. Accessibility may have been significant to the depositional locus. Insect and palynological analyses indicate an expansive change from dense woodland in the Bronze Age followed by a major deforestation; a clearance for agricultural cereals in the Iron Age. Present in the stomach was a fine grit, evidence of the grinding of stone querns used in the processing of flour. Microanalysis of pollen indicates a period of increased wetness several decades before his death as a result of cooler temperatures and wetter climate. An absence of other flora or fauna suggests he was entirely submerged, unexposed to the atmosphere in a pool likely being

\footnotetext{
${ }^{55}$ Don Brothwell, “The Bog Man,” 60-1, 63, 67, Joy, Lindow Man, 36-7, 39-40.

${ }^{56}$ Joy, Lindow Man, 29-32.

${ }^{57}$ Chapman," The Landscape Archaeology of Bog Bodies," Journal of Wetland Archaeology 15 (2015): 109111.
} 
infilled 3cm yearly. Chapman's results from modelling of archive data suggest the locus was far from dry terrain, extremely waterlogged and highly inaccessible. ${ }^{58}$

\section{Radiocarbon Dating}

The radiocarbon date coincides with a period of cultivation and human usage of the area in accordance with evidence of human activity, disturbance of local forest and pollen records of cereals and charcoal remains in the peat. ${ }^{59}$ A large body of research centers on the controversy surrounding the vagueness and possible contamination of the AMS dating due to diverse testing methods by separate labs. The testing of 24 samples was undertaken by two labs, Oxford and Harwell. While Oxford concluded a date of early Roman period $1^{\text {st }}$ century CE, Harwell concluded the late Roman period $5^{\text {th }}-6^{\text {th }}$ century CE. However, they also obtained a stratigraphical date of 750-200BCE, a much earlier date. Oxford obtained three dates extracted from Lindow Man's hair, bone and soft tissue although whether these formed a homogeneous test group remained inconclusive. The soft tissue was the least preserved and possibly contaminated by carbon atoms in the bog which likely contributed to an earlier date. A single vertebra removed during biopsy was divided between the two, from which Oxford extracted seven dates. The first three were compatible with random variation which was filled in by the new dates. The best estimate of the body was a mean from 8 dates of 1940BP (10CE). ${ }^{60}$ The series of Oxford dates pointed to $2 \mathrm{BCE}-119 \mathrm{CE}$, during the Roman invasion, but a significant $30 \%$ chance pertains to a date outside this. Thus, Gowlett questions whether other indirect evidence should be considered more rigorously in the interest of a broader perspective. This might include the armband, cord and charred stomach contents. Present within the stomach was emmer wheat, spelt and hulled barley. Spelt was replaced by emmer wheat in the Iron Age and rye was uncommon until the post-Roman period, ruling out the pre-Iron Age and slotting into the middle-late Iron Age. The most likely explanation for the vast discrepancy pertaining to diverse dates is due to pre-treatment differences between labs and field contamination; sampling errors in pre-treatment failed to remove carbon atoms from the groundwater cross-linked with collagen protein in the body. However, even major

\footnotetext{
${ }^{58}$ Chapman,” The Landscape Archaeology of Bog Bodies," 109-112, 114, 117-8, Joy, Lindow Man, 31, 38. ${ }^{59}$ Lobell, Patel, "Bog Bodies Rediscovered," 22, Connolly, "Britain's Prehistoric Bog Body" 15, Joy, Lindow Man, 12.

${ }^{60}$ Van Der Plicht et. al., "Dating Bog Bodies,"472-3, Gowlett et. al., "Radiocarbon Accelerator (AMS) Dating of Lindow Man." Antiquity 63 (1989): 71-3.
} 
contamination would have a relatively minor effect, making the apparent age older by only 40 years. Both Van Der Plicht et. al. and Gowlett et. al. conclude a date of Roman Iron Age $1^{\text {st }}$ century CE as the most reliably tested but the $30 \%$ inaccuracy sheds doubt on this date. ${ }^{61}$

\section{Interpretational Narratives}

Problematic forensic and dating evidence has resulted in large discrepancies in scientific analyses and a vagueness of knowledge in addition to a patchy archaeological record. This has limited scholars, impelling many to fill these gaps with literary evidence to sustain the empirical data. Several scholars such as Aldhouse-Green, Ross and Giles continue to persist with the traditional orthodox narrative of human sacrifice spurred on by a sentiment of Celtic displacement by Roman Conquest. They largely attribute their authority to the Roman Historian Tacitus whose reliability and accuracy as a historical source will be scrutinized in further chapters. An alternative faction in opposition to the human sacrifice narrative and largely excluded thus far are Hutton and Connolly, who campaign for a reversion to critical discussion and correction of sensationalist tendencies. The foundation of theoretical interpretation can only truly be attributed to the Danish Archaeologist P.V. Glob's publication in 1965 The Bog People, the first comprehensive study of Iron Age bog bodies of north-western Europe. Within a few years it established the most recognizable tropes and served as the founding text of a narrative scholarship characterized by forensic, folk history and popular discourses of poetically pathic proportions. The subsequent Glob-fuelled speculation has led to uniformed sensationalist interpretations of either executed criminals, prisoners of war, social deviants, mugging victims or tortured human sacrifices. The rich spatial and temporal diversity of the archaeological record has been minimized to a panEuropean phenomenon taken out of context and geographical perspective. The following pages will briefly summarize some of modern scholarship's theories exploring a cultural context of violence in the past. Regrettably, summarization prevents a fuller explanation.

\footnotetext{
${ }^{61}$ Van Der Plicht et. al., "Dating Bog Bodies," 472-3, Gowlett et. al., "AMS Dating of Lindow Man,” 71-2, 758.
} 


\section{Bodies as Boundaries}

Kelly attempts to restore individual locality by emphasizing the local significance of the 40 Irish examples by their geographical deposition in proximity to important boundaries. He contextualizes them as part of a wider votive tradition alongside inaugural objects associated with kingly sovereignty, feasting and fertility such as plows and sickles. They were possibly deposed kings indicated by their lacerated nipples which made them ineligible for kingship. This originated from the submissive gesture of nipple sucking as a mark of authority. He interprets the Irish bodies within a context of kingly marriage to the earth goddess during the Celtic harvest festival Lughnasa, ensuring fertility for crops and dairy. He believes this displays the ability to map the Irish political landscape. ${ }^{62}$ However, Giles warns that in the treatment of boundaries, continuity between prehistoric and contemporary boundaries must be carefully demonstrated and not assumed. It is possible there was an attraction to votive deposits which later could have become foci for political boundaries. ${ }^{63}$

\section{Social Selection}

Some scholars believe social selection to have played a significant role in the justification of violence. Aldhouse-Green examines the example of Yde girl whose spine curvature appears to be evidence of social selection on account of physical deformities. ${ }^{64}$ Fredengren investigates the role of fast (i.e.-ritual murder) versus slow violence (i.e.-malnutrition and long term social inequality) in victims not only being selected but groomed for differential treatment prior to their deaths. She characterizes them as "thingified relics" in a necro-politics of exclusion as part of a worldview that defines bodies as political ecologies of localized and

\footnotetext{
${ }^{62}$ Furthermore, he argues as boundaries were typically defined as rivers and lake shores, it was the boundary status, not the presence of water which led to ritualistic deposition. Boundaries carried a protective function and represented a statement of kingly sovereignty. The range of objects suggests this was their primary concern. Kelly, "Secrets of the Bog Bodies," 26-30, Eamonn Kelly, "An Archaeological Interpretation of Irish Iron Age Bog Bodies." in The Archaeology of Violence: Interdisciplinary Approaches, ed. S. Ralph (New York, State University of New York Press, 2012), 237-9, Elizabeth Kim Briggs, Isabella Mulhall, "Presenting a Past Society to a Present Day Audience: Bog Bodies in Iron Age Ireland," Museum Ireland 17 (2007): 77, Isabella Mulhall, "The Peat Men from Clonycavan and Oldcroghan," British Archaeology, January/February 2010, 41, Purdy, "Unearthing the Past," 443, 446, Chapman, "The Landscape Archaeology of Bog Bodies," 109.

${ }^{63}$ Melanie Giles, “Iron Age Bog Bodies of North-Western Europe, Representing the Dead,” Archaeological Dialogues 16, no.1 (2009): 87.

${ }^{64}$ Yde girl was found in 1897 near the village of Yde in the Netherlands. She dates between BCE54-128CE. She appears to have been 16 years old when she died and suffered from scoliosis.

Miranda Aldhouse-Green, "Chaining and Shaming: Images of Defeat, from Llyn Cerrig Bach to Sarmitzegetusa," Oxford Journal of Archaeology 23, no. 3 (2004): 325.
} 
evolving physical archives. She thus suggests sacrifice as a method of managed death to dispose of overly charged objects, thereby reinstating equilibrium. ${ }^{65}$ However, the distinction between socially sanctioned murder or alternative violence is empirically allusive. Parker Pearson points out that we must be wary of ascribing a single motive and of imprinting modern analogies onto the past. He proposes they may have been socially set-apart individuals such as witches or shamans or selected on account of physical or mental disabilities. ${ }^{66}$ The narrative of socially sanctioned human sacrifice is pervasive even in localized contexts but with the disappearance of bogs scholars are beginning to re-examine dates, pathologies and environmental relationships in order to correct the tendency to sensationalize. Particularly injuries previously ascribed to torture such as Windeby girl's (who has recently been more accurately identified as Windeby boy), whose injuries are now being re-ascribed to natural causes. ${ }^{67}$

\section{Traditional Interpretations and Human Sacrifice}

Lindow Man seemed to have been either standing or kneeling when he was struck from behind on the head, strangled, had two ribs broken, possibly from a knee to the back in an effort to restrain him, and his jugular vein severed. Of these, the function of the garrotte and stab wound are most highly contested, primarily by Connolly who believes the neck was broken not by the garrotte but a blow to the head. The garrotte alternatively may have been ornamental or served as a restraint and the stab wound taphonomic (by the crushing weight of the bog). However, Joy maintains no basis exists for its ornamentation. She negates the likelihood of a mugging as his clothes were likely removed rather than stolen. It has yet to be established whether he died during the Iron Age or Roman conquest, whether he was native, foreign or Roman. Joy believes he was a sacrifice killed under Roman occupation in a continuation of earlier Iron Age practices forbidden under Roman Rule. ${ }^{68}$ Giles remains objectively open to the multiplicity of diverse motives and intentions. She also notes the ancient association with bogs of renewal and regeneration as they provided the primary

\footnotetext{
${ }^{65}$ Cristina Fredengren, "Becoming Bog Bodies Sacrifice and Politics of Exclusion as Evidenced in the Deposition of Skeletal Remains in Wetlands Near Uppåkra," Journal of Wetland Archaeology 18, no. 1 (2018): 2-3, 11, 13-6.

${ }^{66}$ Parker-Pearson, "Lindow Man," 17-8, Bridget Brennan, "The Influence of Shamanic Practice on the Deposition of Prehistoric Remains in Bogs" (PhD diss., Institute of Technology, Sligo, 2014), 28.

${ }^{67}$ Lobell, Patel, "Bog Bodies Rediscovered," 23-4.

${ }^{68}$ Joy, Lindow Man, 42-3, 48-52.
} 
source of iron and fuel. ${ }^{69}$ They perhaps expected to be reincarnated after sacrifice or sent into the next realm. They may have been chosen on account of their exceptional skill or as the intercessors of spirits or ancestors, honored and revered. The Late Iron Age/ Early Roman period was characterized by religious and political instability. Perhaps the blows rendering Lindow Man unconscious limited his suffering or ensured his compliance. ${ }^{70}$

\section{A Shaman?}

Aldhouse-Green notes a deliberate manipulation on the part of the killer over the process of death, in hovering on the brink for some time and thus denying access to transition. According to the placement of the trauma there were at least two killers, indicating shared guilt. Perhaps the killers themselves were marginalized, feared, shunned, contaminated individuals. This entailed significant planning, anatomical expertise and exertion of control over the worlds of the living and dead. She envisions the blood acting as a pollutant or purifier, with highly theatrical arterial spurts and agonizing cries, performed at night accompanied by prayers, chanting and lustration ceremonies. The expert craftsmanship of the garrotte suggests a formulaic professionalism. From this she boldly stipulates Lindow Man was a shaman (a two-spirited person) who was symbolically and multifacetedly killed. ${ }^{71}$ Ross takes these re-enactments further still, placing the event at the Beltane festival celebrated on May $1^{\text {st }}$ under the god Belenos, associated with Welsh folklore. Basing her inclinations upon the evidence of his last meal, she declares that the burnt unleavened cake was a deliberate rapid scorching to sear a mark used to single him out for death by random selection. The finality of her argument lies in the suffering of a triple death; a slit throat as an offering to Esus, the watery grave an offering to Teutates and the fire (or burnt bread) an offering to Taranis. He was killed three separate ways: blunt force head trauma, hanged and symbolically drowned, each killing an offering to a different god. From these observations she draws the same conclusion as Aldhouse-Green, that he was a Druid but she assigns him a princely status based upon his fox-fur armband and bestows the name of Lovernios (son of the fox). Further still than placing the exact day, she contextualizes these events in the year 60CE during the high point of British Druidism and the culmination of Roman Druidic

\footnotetext{
${ }^{69}$ Giles, "Iron Age Bog Bodies,” 86-9.

${ }^{70}$ Giles, “Iron Age Bog Bodies,” 86-9.

${ }^{71}$ Aldhouse-Green, Bog Bodies Uncovered, 37, 45, 51, 61-2, 96, 113, 119, 125-6, 132, 137, 143, 159, 175, $192-$ 3.
} 
oppression. ${ }^{72}$ These dramatizations may seem harmless but the sensationalism of violence perpetuates the evolutionary myth of an excessively violent past that infers an innately uncivilized indigenous nature by modern standards.

\section{Critiques of Orthodox Interpretations}

Critiques of the traditionalist approaches breach the issue of a largely-one sided debate and call for a more open, critical dialogue. Fagan critiques Ross' contextualization of exact dates and demographics for "pushing the archaeological envelope with skeptical dating" combined with a patchwork of folklore as late as the $19^{\text {th }}$ century from all over Britain. ${ }^{73}$ Wood emphasizes the impossibility to determine a ritualistic nature from violence as well as the fact that there is seldom any clarity in sacrificial contexts as to whom they were made, particularly given the text-free nature of the period. ${ }^{74}$ Connolly questions the validity of ritual sacrifice or judicial slaughter. If this marks the continuation of a common practice in accordance with Giles, why is the record so scarce? He further doubts Ross' suggestion of the garrotte as a throttle on account of a lack of damage to the gullet cartilages. There is also no evidence of tension around the knot. ${ }^{75}$

\section{Ritualization}

Hutton fully deconstructs the ritualization aspect, originating with Glob's tales of Nerthus' cult in that there is no evidence outside of Tacitus' Germania chapter 19. Adding to the ritualization narrative is the presence of mistletoe found in the stomach which has been linked to Pliny's description of mistletoe as a ritualized drink in victim consecration, a custom before his own time (Plin. Nat. 16.95). Rather it was probably inadvertently consumed on account of the minute quantity and lack of plant remains. Thus, Hutton expunges the triple deaths down to one simple death not compatible as ritual. ${ }^{76}$

\footnotetext{
72 Anne Ross, The Life and Death of a Druid Prince: The Story of Lindow Man, an Archaeological Sensation (New York: Summit Books, 1989), 13, 31-6, 39, 43, 45, 47, 49-50, 53, 58, 101.

${ }^{73}$ Brian Fagan, "Archaeology: The Life and Death of a Druid Prince: The Story of Lindow Man, an Archaeological Sensation. Anne Ross and Don Robins." American Anthropologist 93, no. 3 (1991): 93.

${ }^{74}$ Juliette Wood, "Dying for the Gods: Human Sacrifice in Iron Age and Roman Britain," Folklore 114, no. 1 (April 2003):114.

75 Connolly, "Britain's Prehistoric Bog Body," 17.

${ }^{76}$ Hutton, "Why does Lindow Man Matter?" 140-1, 143-4.
} 


\section{Shamanism debunked}

Brennan gives a summary of Lindow Man's supposed shamanistic traits, most of which may be invalidated due to a lack of empirical evidence. ${ }^{77}$ The excessive violence in overkill may be overturned as misdiagnosed pseudo-pathologies incorrectly prescribed to ritualistic violence but are more likely taphonomic. Other argued ritualistic indications include asphyxiation, the usage of restraints, ingestion of hallucinogens, an aristocratic status alluded to by their manicured hands, the nakedness of the victims or any potential physical deformities which may single them out. However, there is no physical indication of asphyxiation on the body. Thus, this cannot be confirmed by the presence of the garrotte alone. The usage of restraints remains unclear. The ingestion of the hallucinogens may be invalidated for both Lindow and Grauballe Men on account of the small quantities ingested which likely had no noticeable effects. The un-calloused hands and manicured fingernails may also be attributed to the taphonomic processes within the bog as the epidermal layer of skin is eroded by the bog's acidity. The nakedness of victims as a marker for ritualism is dubious at best in the case that recent reviews display 34\% of Late Bronze Age/Early Iron Age victims are not naked. Furthermore, this number is likely to be significantly greater taking preservation bias into account. Lastly, the presence of caps, hats, and armbands as well as physical deformities is not enough to allude to ritualism alone. Within the context of the bog body population, many display no evidence of trauma or any definitive cause of death. This leads Granite to conclude that death by natural causes cannot be overlooked nor interment in the bog for practicality or as a form of special care. These burials may appear ritualized but not represent sacrifice. ${ }^{78}$ Obsession with ritualism draws attention away from other equally valid interpretations which may otherwise be more fully explored.

\section{Harmful Implications}

Hutton exposes underlying harmful assumptions of the human sacrifice narrative. Rather than taking an instinctive benevolent view of ancients, orthodox interpretations have characterized them as savages by crediting them with practices modern society condemns, a method

\footnotetext{
${ }^{77}$ Brennan, "Shamanic Practice," 28, 30-2.

${ }^{78}$ Morten Ravn, "Burials in Bogs; Bronze and Early Iron Age Bog Bodies from Denmark," Acta Archaeologica 81, no.1 (2010): 113, Guinevere Granite, "Understanding the Death and Burial of Northern European Bog Bodies," in Diversity to Sacrifice; Form and Function of Sacrificial Practices in the Ancient World and Beyond, ed. Carrie Ann Murray (New York: State University of New York Press, 2016), 213,217.
} 
similarly used by the Romans to express contempt and hostility. In our own recent colonial history this was utilized by Victorian Britain as a moral justification for European expansionism, exaggerating the more brutal and bloodthirsty aspects of their subjects to justify conversion to Christianity. ${ }^{79}$ In reality the horrific customs condemned by imperialists as bloodthirsty rites have in time been reinterpreted as ancestor veneration. Although this became the normative approach, it evades the archaeology of Iron Age Britain thanks to a small corpus of Roman imperialistic literature. Hutton argues that Lindow Man is the single most significant piece of evidence in Britain used to perpetuate this negative view of Iron Age religion and Druids. He emphasizes how the traditional interpretation is entirely dependent on the dubious AMS dating and the assumption of 'overkill' which led directly to the conclusion of a highly ritualized killing associated with human sacrifice. This was then immediately adopted by the British Museum. The interpretation of the dating evidence rested on the condition of ignoring the later date and repeating the $1^{\text {st }}$-century date uncritically which fitted preconceived notions and disregarded the 30\% inaccuracy of this date. During the Roman period with the outlawing of Druids and the practice of human sacrifice under Roman rule it would have been unlikely, though not impossible for this custom to occur. ${ }^{80}$ These practices may have continued in secrecy, but this assumption has not been proved. Hutton attributes modern historians' tendency to believe human sacrifice to a lack of both textual evidence which would shed light on cultural practices, and lack of modern descendants to defend them. He asserts that inconsistency based on cultural prejudice is unbecoming of good scholarship and throughout opposing scholarship has been consistently ignored. Instead a virtue of uncertainty and recognition of shortcomings should be celebrated. Lindow Man may have been a willing or reluctant sacrifice or a victim of crime or execution during the Iron Age or the Roman period. ${ }^{81}$ The violent events of 2000 years ago, whatever they were, encourage us to explore different understandings of the world, alternative kinds of humanity and to challenge our own attitudes towards life and death. ${ }^{82}$

\footnotetext{
${ }^{79}$ Hutton, "Why does Lindow Man Matter?" 136.

${ }^{80}$ Hutton, "Why does Lindow Man Matter?" 137-41.

${ }^{81}$ Hutton, "Why does Lindow Man Matter?" 142-4.

${ }^{82}$ Hutton, “Why does Lindow Man Matter?” 145, Giles, “Iron Age Bog Bodies,” 95.
} 


\section{Public Exhibition and Reception}

\section{Museum Narratives and Cultural Implications}

Interpretational narratives initiate a cultural flow-on which filters into modern society through media and museums with important consequences for represented demographics. Museums fill the gap between archaeologists, scholars and the public, as the guardians of the material record. This section will compare the display of Lindow Man in the British Museum and the Manchester Museum. As a full descriptor of the British Museum's exhibition is disclosed in the following chapter it will not be mentioned here. The British Museum has been criticized, namely by Hutton, who accuses it of monopolizing the human sacrifice narrative, a narrative which has led to examples of discrimination against modern-day Druids. Comparatively Manchester Museum's exhibit 'Lindow Man: A Bog Body Mystery' has mostly been received successfully. The high preservation of Lindow Man has ignited a morbid fascination in the media filled with inaccuracies and prejudices. The Gazette in 1988 claimed ancient Celtic theocracies were governed by a priestly caste of Druids who ruled the entirety of Scandinavia, The British Isles, France and continental Europe in the $2^{\text {nd }}-3^{\text {rd }}$ centuries BCE and who wearing a serene expression, went willingly to their deaths in the bog. ${ }^{83}$ By contrast in 2004 The Times characterized Lindow Man as "a simple murder victim." ${ }^{84}$ Evidently rarely does the media present the multiplicity of possibilities whilst otherwise vastly overstating motives and drawing huge conclusions. Hutton partially blames the British Museum for the monopoly of the human sacrifice narrative and accuses their exhibition of being a neat summary of the original 1986 report, which was hailed by experts and media alike as certain evidence confirming the verity of ancient authors. He claims the ongoing flow-on effect from this spilled into popular culture over time with damaging effects. One such example is Beth Coomb's publication 'In the Grip of the Druids' which portrays Druids as the mortal enemies of Christianity. Republished in 1997, it spurred a call for the suppression of modern Druidic spirituality. An article in the Guardian in 2007 declared "his killers...still around" and modern British citizens just inches from monstrosity. ${ }^{85}$ Some of the

\footnotetext{
${ }^{83}$ Malcolm Browne, "Body from British Bog Tells Tale of 2,200-Year-Old Human Sacrifice; Tests show Druid's Last Meal Cooked 8 Minutes." The Gazette, March 20, 1988, D8.

${ }^{84}$ Dalya Alberge, "Lindow Man was a Simple Murder Victim," The Times, March 22, 2004, 8.

${ }^{85}$ Jonathon Jones, "Riddle of the Bog," The Guardian, June 21, 2007, https://www.theguardian.com/artanddesign/2007/jun/21/heritage.jonathanjones
} 
narratives extrapolated from scholarly assumptions encourage attitudes of fear and intolerance and invalidate unorthodox non-Christian spiritualities. ${ }^{86}$

\section{Display of Remains}

Also controversial is the British Museum's decision to display Lindow Man's remains. Marie Cox recalls her feelings of disgust and horror upon witnessing the invasive crowding and snapping of photos during her visit, forcing her to question the suitability of his final resting place. ${ }^{87}$ Since the Alder Hay scandal the subject of human remains and repatriation has become much more socially and culturally contentious in Britain. ${ }^{88}$ Old orthodoxies have been questioned and new interpretations proposed. Aldhouse-Green advocates for the deobjectification and humanization of bodies through 3D and facial reconstruction. James questions how, if at all, should human remains be displayed and what should the public expect from museums. Lindow Man, he claims, is so unusual that he must be treated as an "everyman" rather than belonging to one group. Brown questions the role of museums in "provoking debate, prompting cultural understanding and developing a sustainable world" as a postmodern indulgence that may alienate visitors. He highlights the tension faced between education and attraction. At Manchester Museum this issue was tackled in drafting a policy, including a provision for "appropriate, sensitive and informative display." ${ }^{89}$ In response to criticism, the British Museum's display of Lindow Man is now beginning to acknowledge a lack of absolute facts and adopt an empathetic rather than forensic atmosphere to encourage an emotional encounter. These issues will be further explored in the next chapter.

\footnotetext{
${ }^{86}$ Hutton, "Why does Lindow Man Matter?” 138-9.

${ }^{87}$ Marie Cox, Matt McAdam, "Bog Bodies and Bull Scrota." Archaeology 63, no. 4 (2010): 8.

88 The Alder Hay scandal was the case wherein organs were removed from hundreds of deceased children without sought permission in British hospitals.

89 James, "Repatriation, Display and Interpretation." Antiquity 82 (2008): 770-1, 773-4, Bryan Sitch, "Courting Controversy- the Lindow Man Exhibition at the Manchester Museum," University Museums and Collections Journal 2 (2009): 52, Aldhouse-Green, Bog Bodies Uncovered, 77-9, Pete Brown, "Us and them: Who Benefits from Experimental Exhibition Making?" Museum Management and Curatorship 26, no. 2 (2011): 130.
} 


\section{A Case Study: Manchester Museum's 'Lindow Man: A Bog Body Mystery.}

\section{The Importance of Balanced Representation}

Manchester Museum's 2008 exhibition set out to emphasize the plurality of viewpoints and the need for public discussion. A conference was held for public consultation in February 2007 concerning the implementation of the exhibition. New approaches emphasized the importance of place and the liminal nature of bogs. It drew on 25 years of research and explored Lindow Man's differing significance for different people, including marginalized voices such as Pagans. This was in contrast with the previous two exhibitions in 1987 and 1991 which explored forensics and traditional interpretations. ${ }^{90}$ The marketing approach clearly outlined expectations for the exhibit which was divided into four themes; archaeological, scientific, spiritual and nostalgic. This served as the Manchester Museum's approach to incorporate each equally valid, diverse social context. Recordings were featured from Don Brothwell and Melanie Giles (archaeologists), Andrew Mould (the peat cutter who discovered the body), Susan Chadwick (a local girl who recalled the discovery), Emma Restall Or (the founder of the Druid network) and Bryan Sitch and J.D Hill (museum curators). It was laid out into four cells with the body in the middle and the artifacts last. Layered shelving resembled archaeological strata with vast empty spaces to signify a lack of knowledge to be filled with new research. No one voice dominated and the body was left uninterpreted without reconstructions, dialogue or diagrams. Each portrait was supported by visual and audio extracts of interviews, personal items (including a carebear), Iron Age artifacts, forensic equipment, spades and a Pagan wand. This was done to contextualize Lindow Man in respectful reflection, to question evidence, the display of remains and to deconstruct the concept of what defines an exhibition. This was also accompanied by blogs, talks, walks and family activities. ${ }^{91}$

\footnotetext{
${ }^{90}$ Hutton, “Why does Lindow Man Matter?” 145-6, Sitch, “Courting Controversy,” 52.

${ }^{91}$ Sitch, "Courting Controversy" 52, James, "Repatriation, Display and Interpretation," 775, Brown, "Us and Them," 131-4.
} 


\section{The Importance of Public Consultation}

It also sought to spur debate regarding repatriation and display of human remains through encouraging public participation and feedback. There was a 1-5 visitor rating scale for the individual elements of the exhibition. Visitor surveys were conducted for 10 days from November-December 2008, producing a sample of 97 which indicated a clear difference in pre vs. post-visit responses. There was a positive response to staff intervention and a definite shift toward a broader understanding. During its opening from 19/04/08-19/04/09 public opinion was mixed. Conservative criticism included "more hard info, fewer carebears" and questioned the justification for Pagan authority to be on equal par with scientific. ${ }^{92}$ There was opposition to the polyvocalism, lack of factual detail and the innovative design. This was perceived as self-indulgent, superfluous political correctness, a waste of public money and overall a devaluation of curatorial expertise. Furthermore, the inclusion of vocal minorities was perceived as a threat to irreplaceable scientific artifacts without any validated cultural continuity. On account of this the museum drafted a new policy to define remains without descendants as the "collective responsibility...of all residents." 93

\section{Scholarly Critiques}

Sitch admits the body could have been displayed more sensitively whereas Brown asserts it might have been even more overt by clearly explaining the intentionality behind the absence of facts. The lack of information regarding the remains may have been too emotionally or intellectually disturbing and the very act of display turns Lindow Man into a specimen. However, Burch acknowledges it did convey intellectual difficulties while balancing contradictory interpretations. Furthermore, it effectively created a sense of community engagement in local history and confirmed the need for public consultation and review of the development processes. ${ }^{94}$ Academic responses are predominantly positive, and the exhibition claimed the Wo 2009 design week award for Best Temporary Exhibition. Manchester

\footnotetext{
92 Stuart Burch, “Lindow Man: A Bog Mystery, Manchester Museum,” Museums Journal 108 (2008): 46-7.

93 Brown, "Us and Them," 133-4, 136-8, 140, 142, Giles, "Iron Age Bog Bodies," 93, Sitch, "Courting Controversy," 52-3.

${ }^{94}$ Burch, "Lindow Man: A bog Body Mystery," 47.
} 
Museum's approach casts into high relief the role of conflicting ideas between museums and scholarship in national identity. ${ }^{95}$

\section{Conclusion}

\section{The Danish Examples and Lindow Man}

By the discovery of Lindow Man in 1984 Glob's narrative of human sacrifice was thoroughly well-established, providing a pre-existing framework within which Lindow Man could be slotted into without much critical analysis. Subsequently scientific investigations have facilitated this framework in an approach of manipulating empirical evidence to resemble notions of extreme violence with the allusion to sacrifice. There is much to be said in comparing the Danish examples and Lindow Man.

\section{Conservation}

Tollund and Grauballe Men were the first well-preserved bodies uncovered, therefore there was little to no knowledge of conservation methods. Unfortunately, this meant Tollund Man became a conservational experiment. He was deemed too difficult and macabre to be preserved entirely and his body was left to dry out, while only the right foot and head were preserved, suffering a $12 \%$ shrinkage. By contrast, only two years later and thanks mainly to Glob, the preservation of Grauballe Man's entire body was undertaken successfully by Conservator Lange-Kornbak after a 10-day exhibition to 18,000 people. He achieved this by taking a naturalistic approach to complete the tanning process begun by the bog. The body was immersed in a solution of one-third fresh oak and two-thirds oak bark in distilled water and the chest cavity was stuffed with filler for aesthetic purposes. By 1984, technological advances meant Lindow Man was freeze-dried and suffered a mere 5\% shrinkage.

\footnotetext{
${ }^{95}$ Hutton, "Why does Lindow Man Matter?" 145-6, Sitch, "Courting Controversy,"53, Brown, "Us and Them,"133-4, 145-6, Giles, "Iron Age Bog Bodies," 94.
} 


\section{Display}

The display of both Tollund Man in the Silkeborg Museum and Grauballe Man in the Moesgaard Museum are sensitive, dimly lit displays to encourage an aura of reverence and meditative reflection. The Moesgaard Museum presents both old and new perspectives with Grauballe Man's presence dispersed across diverse interactive media, existing not solely as a physical entity. Contrarily, the British Museum has previously opted for a singular narrative of human sacrifice in what Hutton describes as a neat summary of the 1986 report. Although it now acknowledges some uncertainty surrounding this and has structured a more empathetic encounter.

\section{Scientific Analyses}

Both Tollund and Grauballe Men have been extensively investigated both in the past and more recently. Recent investigations have offered new insights and a revision to once accepted conclusions, exposing old fallacies and allowing the opportunity to construct empirical-based interpretations. Isotope analyses have displayed Tollund Man's purely terrestrial diet which may be combined with environmental data to reconstruct Iron Age subsistence and lifestyle in a holistic, multi-disciplinary approach. CT scans expose a throttled hyoid bone, confirming the cause of death as hanging. First dated in 1977, in 2000 Nielson et al. dated him with 95\% confidence to 405-380BCE and in 2014 Charlier discovered elevated plantar formations of the papillomavirus on the soles of his feet. In 20012 a team led by scholars Asingh and Lynnerup performed a re-examination of Grauballe Man's initial investigations to document and preserve him for posterity. They discovered 334-754 sclerotia of ergot in his stomach, a minuscule enough amount to eliminate speculation that it was used as a ritualistic hallucinogenic and to confirm Helbaek's original conclusion as safe for consumption. This lies in stark contrast to continual deliberation of mistletoe in Lindow Man's stomach which was likely similarly ingested inadvertently without ritualistic intention. In 1979 Grauballe Man was dated by Henrik Tauber to 110BCE50CE and re-dated in 1996 to 400-200BCE with hair samples. In 2001 Gregersen et al. dated a sample of roots that had penetrated his gut to 490-230BCE with an average date most accurately of 390BCE. Results of CT scans confirmed the cranial fracture was taphonomic which led Lynnerup to emphasize the commonality of pseudo-pathology and re-ascribe this as the effects of post-mortem diagenesis rather than the presence of extreme violence or overkill. Such revision has not been likewise applied to Lindow Man's investigations. His 
scholarship continues to rely solely upon the initial 1986 report which stated a highly contentious stab wound, fractured ribs, cranial fracture and broken neck. These injuries have been uncritically accepted without further recent investigation, particularly in light of improved technological methodologies available, such as was utilized in the re-investigations of Grauballe Man. Furthermore, more accurate dating of Lindow Man has not been reattempted and the highly contentious Oxford date of 2BCE-119CE with an error margin of $30 \%$ has been accepted. This necessitates a revision, such as performed on Grauballe Man, to the initial findings which would focus on identifying pseudo-pathology, as well as establishing with confidence a precise date. This would allow a deconstruction of the interpretational myths that have plagued Lindow Man's narrative and a return to empirically based interpretations.

\section{Interpretational narratives}

The narratives surrounding Lindow Man's death perpetrated by some modern scholars exhibit Glob's pervasive sweeping generalizations of extreme violence in a romanticized ancient ideology based in folklore and rich in poetic pathos. While in Denmark this has beneficially cultivated a national self-respect and sense of pride, in Britain this has allowed for the characterization of the ancients as savages by exaggerating brutality and cultivating a negative portrayal of Druids and Iron Age religion. The possibility of sacrifice cannot be excluded but it does not hold enough legitimacy to maintain its current dominance. All scholars acknowledge there is no universal explanation yet in practice this has not taken hold. Instead scholarship has tended to rely on sweeping generalizations rather than a case-by-case approach rooted in empirical data to foster individual interpretations. Furthermore, this exposes the divide between empirical data and interpretative assumptions. Archaeology is hindered by the limitations of empirical data derived from a material record that cannot convey human intentionality in the past. Perhaps then, it is best to adopt, as Hutton suggests, a campaign that celebrates investigative limits and the absence of facts. The next chapter will expand on the issues of exhibition and the implications of narratives in the public arena. 


\section{Museum and Heritage Ethics}

\section{Introduction}

Museum ethics regarding the treatment of bog bodies is multifaceted on account of their unique heritage significance and the challenges presented in depicting this. Their embodiment as archaeological remains ignites ethical conflict regarding disturbance and display.

\section{Scholarship surrounding Disturbance of the Dead}

Bahn asserts that the disturbance of the dead is inherently offensive and violates many cultural beliefs. Dismissal of Pagan beliefs as fallacious has led the Council of British Druid Orders (CoBDO) to declare a double standard of differential treatment between Pagan and Christian remains. Public display with little reverence robs remains of individuality and humanity. They call for reburial as the most humane solution. Giles argues that the complicated nature of violent death inverts the moral boundaries of disturbance wherein offense may be neutralized through advocacy as the circumstances surrounding their deaths are unveiled. Scarre concurs that if oblivion is a form of indignity, interpretations hold abstraction at bay as a form of empowerment, particularly for those who have been denied their rights in life.

\section{Scholarship regarding Display of Remains}

Alberti et. al. present well-balanced arguments both for and against public display. Benefits include igniting widespread public interest, providing a first-hand experience of death and revealing the diverse lives of past peoples, only otherwise surmised through artifacts. However, it may also treat bodies as things, disrespect the dead's interests and create an artificial experience of death which undermines the educational value and can become unnecessary sensationalism. It could be argued that the display of remains reflects modern values greater than past culture. Modern morbid curiosity fetishizes death, desensitizes violence and violates bodily integrity. However, this can be mitigated through consideration of each circumstance within a context of professional consciousness to reach a suitable compromise. Giles and McLean advise that display must be undertaken with public 
consideration and Sanders adds that it should be done sensitively, without compromising authenticity. Too often the boundary between authentic display and the transformation into art is obfuscated by the static freeze-frame nature of exhibitions. Sanders dubs this the 'museum effect,' which describes a heightening of visual interest created through lighting, photography and isolation. This results in de-contextualization and abstraction from reality, diminishing authenticity.

\section{Two Case Studies}

Two comparative case studies that explore issues surrounding appropriate display are the British Museums' display of Lindow Man within 'The Celts' exhibit and the National Museum of Ireland's (NMI) exhibition 'Kingship and Sacrifice.' The British Museum's display of Lindow Man's remains achieved some empathetic sentiment but was largely insensitive due to the isolation of remains lacking cultural context. Whereas the NMI achieved a sensitive display situated within a greater cultural context and far removed from sensationalism.

\section{Museums and Social Responsibility}

The underlying principles of an exhibition should be an engagement with social consciousness and an institutional obligation for social responsibility. Traditionally museums have opted for an authoritarian approach to protect institutional authority while remaining aloof from competing views. Now objectivity is widely acknowledged to be realistically unobtainable. Museums inhabit the unique role of stewards, not spectators. They are beginning to strive for diverse representation which opens them up to greater scrutiny but also cultivates a democratic platform of public feedback. Harris warns that institutions which seek to avoid controversy become the subject of criticism. Controversy should be neither a criterion for nor hindrance to exhibition production. Walker Laird asserts that museums have a social responsibility to protest moral and political indignation against politicization in the discovery and use of historical evidence. 


\section{Disturbance of the Dead}

\section{Rights of the Dead}

Disturbance as a form of transgression against the dead ignites much ethical debate. It explores scientific versus personal interests for digging up the past and raises questions surrounding ownership of the past and the treatment of particularly Pagan remains. Bahn perceives exhumation as inherently offensive both to the dead and their descendants. Disturbance violates many cultures' belief in the afterlife by the robbing of corporeal integrity and grave goods. Giles believes careful exhumation is necessary to avoid complete destruction of remains and when conducted in conjunction with represented communities it may offer respect for cultural diversity in the past. Scientific endeavors can achieve respectful treatment of the dead. How and why knowledge is gathered and who is authorized to disseminate it varies considerably between cultures and therefore this should be judged on a case-by-case basis. ${ }^{96}$

\section{Treatment of Pagan vs Christian Remains}

Homogenization of beliefs in the afterlife makes it easier to write off diverse cultural practices as fallacious, for example the Druidic obsession with Stonehenge. Pagan beliefs are dismissed as incorrect or not considered. By contrast Christian burials are treated with greater reverence and have been superimposed onto Pagan remains, such as the reburial of bog bodies in churchyards. This ideological double standard sometimes manifests in professional archaeological practice. ${ }^{97}$ Excavation in Britain is currently framed by national legislation such as the 'Burial Act' (1857), 'Disused Burial Grounds Act' (1981), and the 'Planning and Policy Guide' (1990). The discovery of archaeological remains must be reported to the Ministry of Justice before a license for excavation is granted. A policy of non-disturbance unless for a 'good and proper reason' is endorsed, pending the demonstration that the accrual

\footnotetext{
${ }^{96}$ Giles, "Iron Age Bog Bodies," 76, 81, Paul Bahn, "Do not Disturb? Archaeology and the Rights of the Dead," Journal of Applied Philosophy 1, no.2 (1984): 214.

${ }^{97}$ Bahn, "Do not Disturb?" 214-8.
} 
of knowledge outweighs the value of undisturbed preservation. Despite this, some believe in the need to address concerns that archaeology fails to treat Pagan remains with the same dignity afforded to Christian remains. The CoBDO denounces any disturbance as they believe remains are inherently treated as archaeological objects and displayed in highly public settings with little reverence. Therefore, they assert reburial corrects the injustice of disturbance. ${ }^{98}$ Furthermore, Scarre believes academic archaeologists are guilty of neglect as remains are not always treated with a timeless human status. ${ }^{99}$

\section{Interests of the Dead}

Giles believes in a moral obligation to the dead as custodians of their remains. Importance of place in the construction of social memory infers most formal burials were made to remain undisturbed. However, the violent deaths suffered by the bog victims make it difficult to infer the deceased's original intentions. Therefore, the circumstances of their deaths deserve to be revealed. ${ }^{100}$ Wilkinson believes that our treatment of the dead can be guided by adhering to a symmetry between the interests of the dead and the living, under the impression that the weight of such does not decline over time. Posthumous interests, which the dead have for their post-mortem selves whilst alive, matter in their own right after death. Privacy in regards to disturbance is just one of many. Two ideas stand to oppose this; the dead are ignorant and therefore unharmed, which presupposes that something is better or worse for knowledge of it, and can the dead be harmed? In presupposing an indefensible doctrine of backward causation-does harm post-mortem harm the antemortem person? He concludes that the interests of the living and dead should be treated as symmetrical where similar. ${ }^{101}$ Scarre adds that death does not mark the termination of interests and that disturbance subverts dignity by drawing attention to the state of death. Although he assumes a western perspective that death is inherently undignified. Difficulty in showing respect lies in differing cultural values over

\footnotetext{
${ }^{98}$ CoBDO, "Request for the Reburial of Human Remains and Grave Goods, Avebury," Appendix 1, accessed June 22, 2020, https://www.academia.edu/12766795/Request_for_the_Reburial_of_Ancestral_Human_Remains_at_Avebury Wiltshire 2008 ?auto=download.

${ }^{99}$ Geoffrey Scarre, “Archaeology and Respect for the Dead," Journal of Applied Philosophy 20, no.3 (2003): 238-41, Giles, "Iron Age Bog Bodies," 78-80.

${ }^{100}$ Giles, "Iron Age Bog Bodies," 80.

${ }^{101}$ T.M Wilkinson, "Last Rights: The Ethics of Research on the Dead," Journal of Applied Philosophy 19, no.1 (2002): 30, 32-5.
} 
time and space which renders it unlikely that the archaeologist's purpose should be understood by the subject. When our own purpose is superimposed on remains, they invest them with alien meaning. He believes that remains are hence viewed as anonymous representatives rather than distinct individuals ${ }^{102}$. However, bog bodies provide a unique representation of the individual. The role of the archaeologist as custodian is a welcome change to the image of an investigator who exploits but remains should never be treated as a means to an end. However, if oblivion is a form of indignity, revelations are a stronger counter to oblivion than undisturbed preservation. Disturbance is not always a disservice but all relative interests must be weighed equally. ${ }^{103}$ The claim is not that research should not be undertaken, but should be undertaken in consideration of both the importance of the research and the likelihood of the deceased's interests. ${ }^{104}$ In the case of bog bodies, their interests cannot be assumed as the nature of their deaths remains unclear yet their circumstances deserve to be revealed. Archaeologists carry an obligation to do so which outweighs the potential harm caused by disturbance.

\section{Display of Remains}

\section{Should the Dead be Displayed?}

Display of human remains is an issue pertinent to bog bodies, many of which are on display permanently throughout Europe and the UK. If the motivation behind their disturbance is to reveal the circumstances of their death, the purpose of their display is to unveil these circumstances. However, the display of remains, taken to mean the physical presentation of human remains in a public arena, carries its own controversies. It serves to spark public interest, widen the participation agenda beyond academia and offers experience with death in an otherwise removed society. Alternatively, it may objectify remains and not create a

\footnotetext{
${ }^{102}$ Scarre, “Archaeology and Respect for the Dead," 237-8, 241-9.

${ }^{103}$ Scarre, "Archaeology and Respect for the Dead," 237-8, 241-9.

${ }^{104}$ Wilkinson, "Last Rights," 37-8.
} 
realistic experience or provide anything of educational value not unachievable through digital techniques.

\section{Pros}

Alberti et al. enumerate the constructiveness of displaying remains in cultivating public interest. Displaying remains breathes life into the past only otherwise surmised through artifacts. ${ }^{105}$ Bahn adds that display can lend exposure to the deceased's identity and raise insight unattainable from artifacts into race, subsistence, paleopathology and socio-economic conditions. ${ }^{106}$ In a society isolated from death, it provides an often first experience of natural human mortality. Museums trade on a literal face-to-face experience of the past from which techniques such as facial reconstruction provide an extra biocultural perspective. Death should be examined in a mature manner which demonstrates acceptance of a finite existence. Problematically, well-preserved remains may provoke negative responses of shock and horror. Analyzing these responses and reflecting on our own emotions regarding death helps us to understand and accept how death is culturally constructed in diverse ways. This may be integrated into displays by attempting to understand how the deceased perceived life and creating a connection with the past. ${ }^{107}$

\section{Cons}

Contrarily, Alberti et. al. also enumerate the negatives. Display of human remains may treat bodies as artifacts and disrespect the interests of the dead. Remains inserted into a particular context for contingency purposes may be transformed into a preserved specimen. This creates an artificial experience of death and distances the viewer through obscurity, becoming unnecessary and sensationalist rather than educational. They argue that educational value might be better achieved with artificial models and digital techniques in a more respectful, sustainable and cheaper manner. Furthermore, it is impossible to gain informed consent from the ancient dead. However, this line of thought would imply that digital reconstructions are also a violation of the deceased's privacy. They believe it is a reflection of modern western

\footnotetext{
105 J.M.M Alberti et al., "Should we Display the Dead?" Museum and Society 7, no.3 (Nov. 2009): 135-7.

${ }^{106}$ Bahn, "Do not Disturb?" 221-3.

${ }^{107}$ Giles, "Iron Age Bog Bodies,” 76, 78, 89-90, Alberti et al., "Should we Display the Dead?” 135-7, 142-4.
} 
society's need to "feed an inordinate taste for the macabre while masquerading science as education." 108 Bahn maintains that display does not consider the dead's interests and any justification based on modern benefit is cold comfort for the dead. ${ }^{109}$

\section{Ottawa Museum of Civilisation's 'The Mysterious Bog People'}

One example which illustrates these issues clearly is the Ottawa Museum of Civilisation's 2002 exhibition 'The Mysterious Bog People: Rituals and Sacrifice in Ancient Europe,' which consisted of seven bodies and 400 artifacts. Within the first few days the media reported a strong negative public reception to the marketing campaign, which saw souvenirs of bags, posters, pens, books and t-shirts sporting Yde girl's face. One quote from the Ottawa citizen stated, "T-shirts displaying images of rotting corpses apparently passed the taste test and are on sale." With an attendance of 15,000 in over a year, the vast majority of feedback was positive. This is an example of how conflict could have been avoided through cultural sensitivity and careful planning. ${ }^{110}$

\section{Justifying Display}

Display of the dead may be most justified by assuming a role of advocacy on behalf of the dead. This is particularly true of those who were possibly marginalized by their own contemporary dominant discourse and unable to advocate for themselves. There remains no simple solution. Each circumstance must be individually evaluated with consideration of any living descendants and within the deceased's interests as much as can be discerned to reach a suitable compromise. It is a question of balancing the means and the ends. ${ }^{111}$ With bog bodies, this is most evident wherein there is a moral obligation to unveil their suffering lest their deaths be in vain. By displaying them in an appropriate manner and within suitably constructed exhibits we are able to connect with their pain and shared humanity. Empathy is key in learning from violence in the past which the bog victims represent. Seamus Heaney

\footnotetext{
108 Alberti et al., "Should we Display the Dead?" 137-42.

${ }^{109}$ Bahn, "Do not Disturb?" 221-3.

${ }^{110}$ Alternatively, there are examples of positive cultural appropriations of death such as the Catholic display of Saints. Heaney draws such a comparison between the bog bodies and sainthood in his bog poems.

Heather Gill-Robinson, "Bog Bodies on Display,” Journal of Wetland Archaeology 4, no.1 (2004): 111-3, 115.

${ }^{111}$ Giles, “Iron Age Bog Bodies,” 81, 89-90.
} 
also explores how present violence may be broken by reflecting on the past. This will be further explored in the final chapter.

\section{Building Appropriate Exhibitions to Display Remains}

\section{Exhibition Construction}

The exhibition of bog bodies is taken to mean the display of remains incorporated within an interpretational and cultural context. Exhibitions must address the above concerns during the construction process. One method of addressing concerns is engaging in public consultation. Giles warns that curators who refuse to enter into dialogue with public opinion should be cautious as she believes it is an integral aspect. ${ }^{112}$ However, it may be misconstrued as a proactive step towards repatriation and reburial and perceived as a threat to irreplaceable scientific resources. This raises the question of whether local communities have a legitimate claim to participate in museological decision-making. The strength of local attachment is often evident from public support for regional repatriation, as in the case of Lindow Man. The value of human remains should be assessed by the cultural capital they represent to communities who use the past to define their sense of identity, place and history. It is incumbent on curators to articulate this value in order to defend the motivation behind exhibitions. ${ }^{113}$ Curators should first consult with special interest groups before choosing to display remains and weigh up opinion against their own professional discretion. In the case of bog bodies, many do not have any interest groups such as descendants. Thereby they obtain a collective responsibility. In any case, the responsibility of decision-making falls to the curator. McLean explains that the process of constructing exhibitions can be deconstructed into interpretations which are generated during excavation and analysis, then presented in a way to portray human perspective. This involves the relational character of memory as a trajectory of diverse non-static collectives continually undergoing transformation. McLean advocates for public talkback in constructing dialogues which encourage visitors to raise

\footnotetext{
${ }^{112}$ Giles, "Iron Age Bog Bodies," 92-4.

${ }^{113}$ Giles, "Iron Age Bog Bodies," 92-4.
} 
questions and discuss opinions. Exhibitions should include "talk-back" spaces which stimulate visitor responses. Museums should be a marketplace of ideas where visitors should be heard, not solely seen and exhibitions should allow for expression of conflicting views. ${ }^{114}$ Despite the average museum-goer's general ignorance towards bog bodies, public feedback regarding how exhibitions are constructed and remains are displayed have proved extremely useful for understanding the effectiveness of exhibitions.

\section{Presenting Remains within Cultural Context}

Once justification for display is established, the question remains of how best to display them within cultural context and without objectification. Sanders believes the exhibitions of both Tollund and Grauballe Men invoke tension between presenting scientific information and artistic license. ${ }^{115}$

\section{Tollund Man's Exhibit}

Sanders describes Tollund Man's exhibit as a curious hybrid of photographic preservation and museum technology, replacing reality by amalgamating the original with a copy. Photography has become the most authentic access to his originality in replacing his now-gone body. A replica of his remains is displayed alongside the only parts which are left of him-his head

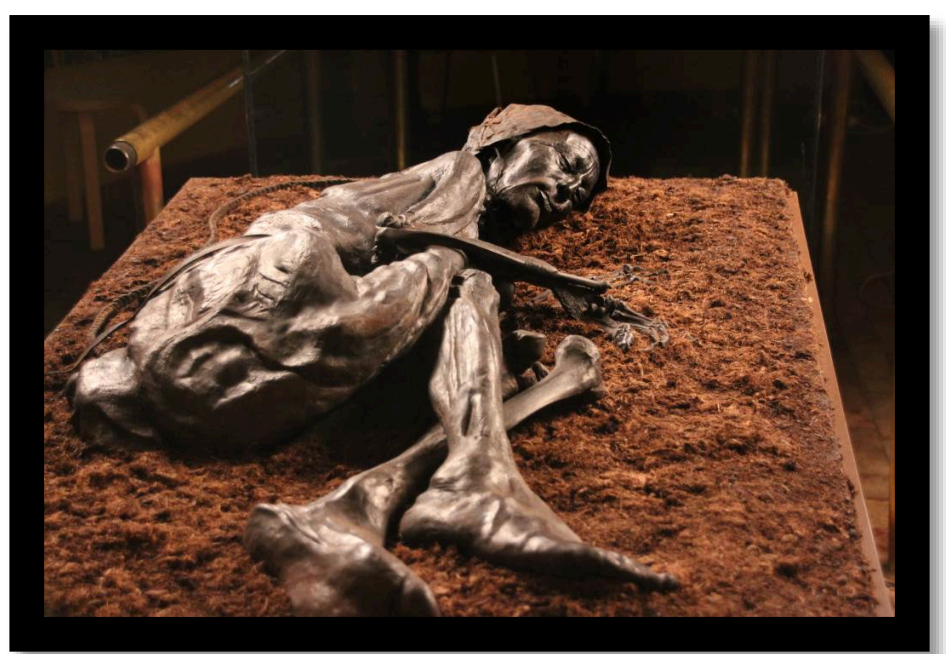

Figure 9-Tollund Man on display at the Silkeborg Museum.

Photo Ole Nielsen. and foot. Therefore, she likens the display of Tollund Man to an open casket of what no longer exists, undermining his authenticity. ${ }^{116}$ However, there are few other options to restore Tollund Man's image with regard to his unfortunate preservation.

\footnotetext{
${ }^{114}$ McLean, "Bodies from the Bog,” 305-7, 215, 224.

${ }^{115}$ Karin Sanders, Bodies in the Bog and the Archaeological Imagination (Chicago: University of Chicago Press, 2012), 30.

116 Sanders, Bodies in the Bog, 30.
} 


\section{Grauballe Man's Exhibit}

Grauballe Man is exhibited alongside Tacitean quotes and excavation photos, designed as a "tomb with a view." Under this guise the body is reinterred but unnaturally frozen in time. Through photography he is reborn but lingers stuck in that one point in time also. ${ }^{117}$

\section{The 'Museum Effect'}

The line between presentation and becoming an object of fine art is obfuscated, exploring the chasm between art and nature. The act of re-experiencing an intentionally cultivated and culturally fabricated body is a "cognitive pendulum between frozen and unfrozen pasts, the blurring of borders between fine art and archaeology" at

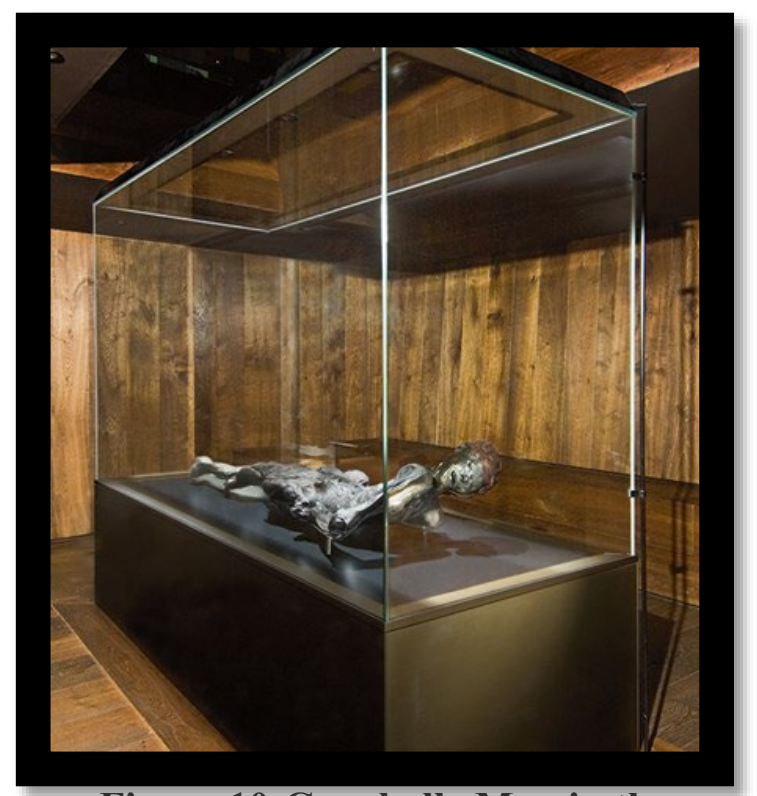

Figure 10-Grauballe Man in the Moesgaard Museum.

Photo Museum Moesgaard, viewed 25 August 2020.

https://www.moesgaardmuseum.dk/media/4713/04 05_30844.jpg an institutionalized level. ${ }^{118}$ This phenomenon, termed 'the museum effect' describes heightened visual interest through isolation and lighting. Bodies begin to resemble sculptures, resulting in manufactured reverence as they are decontextualized. They begin to inhabit a zone between natural objects and fabricated artifacts, art and archaeology. To counteract this, curatorial strategies such as facial reconstruction seek to rehumanize and restore humanity. This conflict is further enhanced with victims of violence. Violence represents a destruction of life. It challenges our viewing ethics and blurs the lines between morbid curiosity and scientific interest. Cultivating the viewer's empathy helps to mitigate this. Empathy based on shared humanity is the key to combat objectification. ${ }^{119}$ The museum effect undermines authenticity, but sensitive displays recover a sense of personhood. Authenticity is both seductive and deceptive. It promises direct access to an uncorrupted reality while necessitating subjective certification by the curator. Belying this is not the substance of reality but authority obtained from human expertise which may be compromised. Sanders

\footnotetext{
${ }^{117}$ Sanders, Bodies in the Bog, 177.

${ }^{118}$ Sanders, Bodies in the Bog, 24, 33, 37,169-71.

${ }^{119}$ Sanders, Bodies in the Bog, 175-6, 178-9, 192-4.
} 
believes that museums submit to an inherently inauthentic presentation. ${ }^{120}$ Valuable objects are protected from touch for longevity, the most tangible human approach to material culture. Denial of tactility enhances alternative senses. Passive relations become active and the notion of spectacle is transformed into an emotional response by proxy of information. In Sander's mind the borderline between the entertainment industry and museum strategies is becoming increasingly blurred by inauthentic presentation. ${ }^{121}$ Complete authenticity may be unobtainable, but museums can strive for sensitive and empathetic exhibits which combat objectification and restore our shared humanity.

\section{Two Case Studies: The British Museum and the National Museum of Ireland}

According to the author's observations, sensitivity of display and suitability of exhibitions may be compared between the British Museum's display of Lindow Man and the National Museum of Ireland's display of four Irish bodies, including Old Croghan man and Clonycavan man.

\section{The British Museum}

Lindow Man is located within the exhibition of 'The Celts.' Entering into the large, rectangular room filled with Celtic artifacts, it is not immediately obvious that his remains occupy the farright corner. The exhibit follows the general layout of the museum. Each room is organized according to period and cultural groupings. This is rigidly dictated

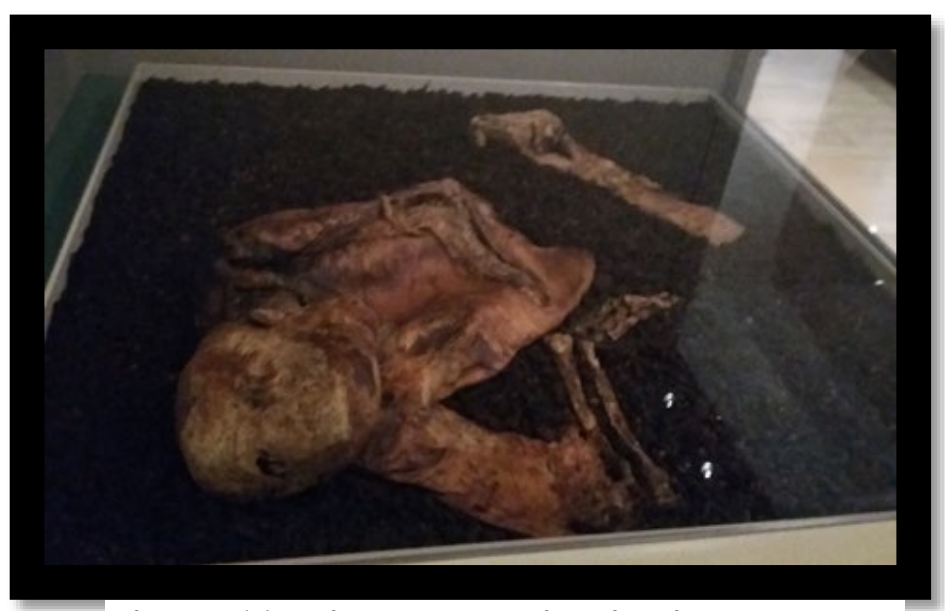

Figure 11: Lindow Man in his display case.

\footnotetext{
${ }^{120}$ Sanders, Bodies in the Bog, 194-6.

${ }^{121}$ Sanders, Bodies in the Bog, 222, 173-6.
} 
partially by the structural layout and partially by the broadness of content, covering huge expanses of human history but lacking any real depth.

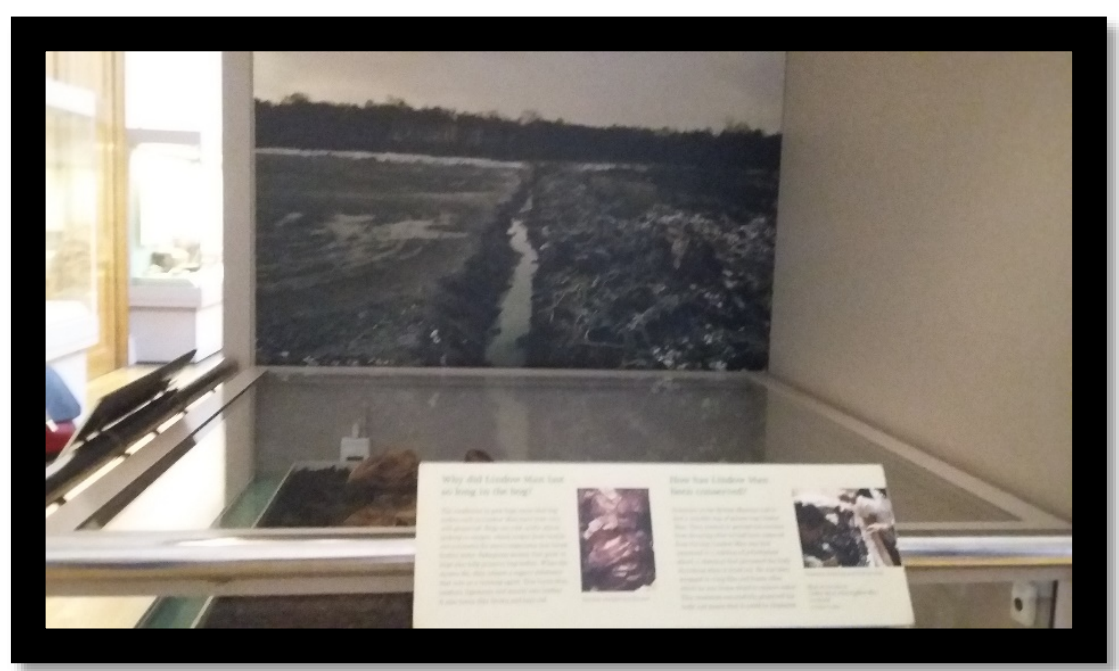

Figure 12: The case with panels and backdrop.
The body is boxed off and hidden from general view without any signposting. He lies in a glass case encircled by a handrail and backdropped with bog images. Two information panels deck the handrail and another the opposite wall. Dull lights illuminate the body from above as he lies on a bed of fake moss.

The panels detail a violent death, outlining his sustainment of multiple injuries including the contended blow to the head and stab wound, and present solely the Oxford date in accordance with Roman Conquest. This narrative almost entirely dominates excepting one sentence on the opposite panel of alternative interpretations. The handrail panels acknowledge the conclusion of mistletoe as indeliberate and mention Connolly's suggestion of the garrotte as possibly ornamental. The small space between the enclosure and the wall limits traffic flow but does nothing to deter people from hanging over the handrails snapping photos intrusively. This suggests to the author an appeal of shock value which is further enhanced with the minimal information and lack of context.

Observations on the nature of visitor interaction revealed little attention was paid to the information but was instead directed toward the corpse. Average time spent interacting with the exhibit was about one-two minutes. Many simply took photos and left. In summation, the display of remains was partially empathetic although the exhibit as a whole did not attain sensitivity and was isolated from cultural context. Although some attempt has been made to create a sensitive atmosphere, not enough has been done to achieve a respectful and reflective space. 


\section{The National Museum of Ireland}

The British Museum's display of Lindow Man may be compared to the National Museum of Ireland's exhibition 'Kingship and Sacrifice', constructed on the interpretations of Eamonn Kelly. Prior to its opening in 2006, 'Kingship and Sacrifice' sought to sensitively display the remains of four Irish bog bodies within the cultural context of a range of other related votive bog finds. Underlining the exhibition's purpose were several educational goals: to explore how these human remains came to be deposited in bogs during the Iron Age, to determine some rationale behind

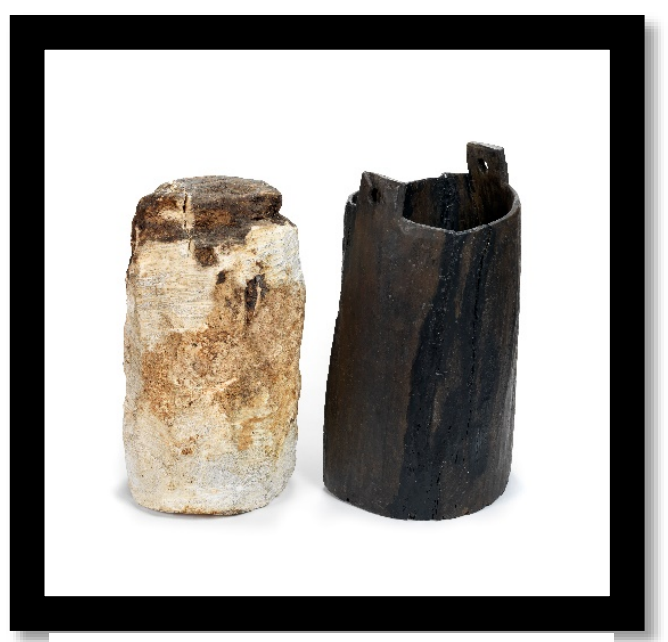

Figure 14: Rosberry bog butter and container.

(C) National Museum of Ireland their deaths in order to gain a greater appreciation for Iron Age culture in Ireland, and to introduce visitors to the rich heritage of the Irish boglands. In

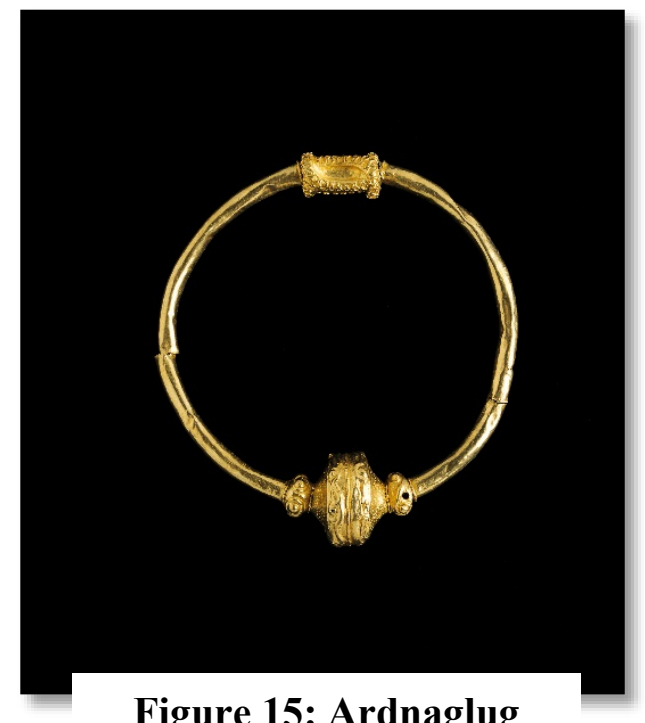

Figure 15: Ardnaglug Gold Collar.

(C) National Museum of Ireland the pursuit of sensitivity, three principal issues were considered: what is the most appropriate approach to a highly sensitive subject, how to present wide-ranging findings to the general public and lastly, how to facilitate an understanding of geographical boundaries in light of kingship and inauguration. During the planning process other exhibitions including the Manchester, Moesgaard and Silkeborg Museums were used as models. A team of 35 international specialists including an exhibition architect were consulted on lighting, temperature control and positioning of the bodies within the exhibit. In contrast to the British Museum's rigid exhibition design, it was decided to present the artifacts, scientific findings and kingship interpretation in the center of the exhibit. The bodies in close proximity flank the information yet are removed from it inside specifically constructed signposted spaces. They are blocked from view, allowing visitors the personal choice in viewing. This is further in stark contrast with the British Museum. 
Information is presented by three main components: a slideshow, highlights and a doublesided interactive kiosk. The entire exhibit is organized into a continuous narrative depicting the geography of bogs, a distribution of maps and Iron Age artifacts (categorized into associations with sovereignty, fertility, feasting, procession, kingly attire and weaponry), and lastly the bodies themselves. The physicality of the exhibit reflects these themes. An earthy

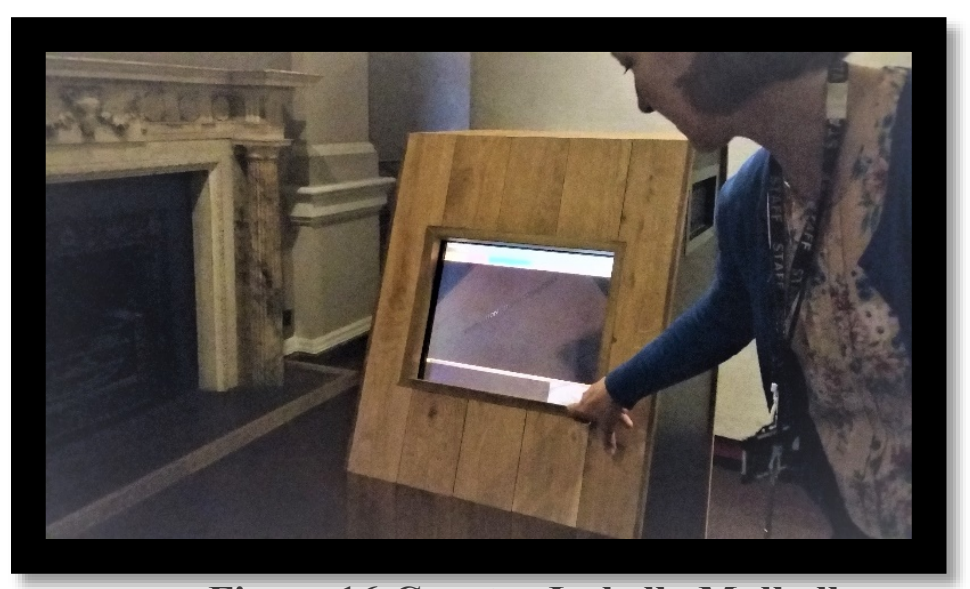

Figure 16-Curator Isabella Mulhall demonstrates the interactive kiosk.

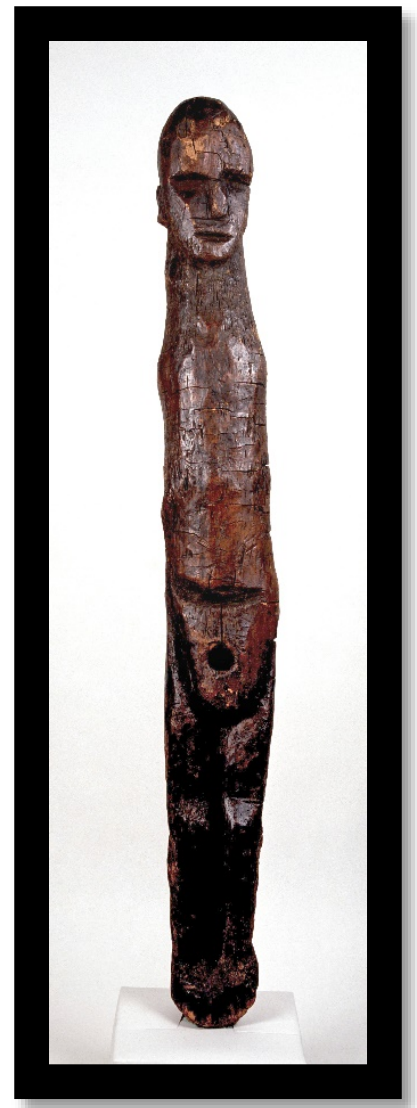

Figure 17:

Ralaghan Man

(C) National Museum of Ireland

brown floor represents the

Iron Age trackways and a general appearance of terrain is

established with natural browns, oranges and reds, enhanced by imagery of flora, fauna and bogs. Everything is constructed of allnatural materials. ${ }^{122}$

The remains rest in an exhibition case in the center of individual circular enclosures, viewed in complete isolation in a dignified manner to avoid sensationalization and trivialization. To counter the lack of information inside the enclosure, panels are located at the entrances. Enclosures consist of a dimly lit, neutrally painted space with parallel wooden seats to encourage a sensitive, reflective and reverent encounter. Unlike at the British Museum, visitors took no photos or hung over the remains but sat quietly to observe from a distance or came face-to-face. The circular design removed congestion and permitted a more personal, intimate experience, with generally at most three people at any one time. Mulhall explains the bodies narrate stories of life and death, trauma and violence, unachievable through artifacts alone. ${ }^{123}$

\footnotetext{
${ }^{122}$ Briggs, Mulhall, "Presenting a Past Society," 71-2, 75-8.

${ }^{123}$ Briggs, Mulhall, "Presenting a Past Society," 75, Isabella Mulhall, personal conversation, August 9, 2019.
} 
Lastly the exhibit provides ample opportunity for public feedback through both comment cards and email. Feedback typically consists of queries by those whose interests have been peaked or observations which are addressed and implemented during staff monthly meetings. Thus far no negative feedback has been received. Mulhall asserts that curators must be mindful that each visitor has their own interpretation. ${ }^{124}$

\section{Museums and Social Consciousness}

\section{Traditional Authoritarianism}

Museums, as the product of people's endeavors, maintain influence over class, ethnicity, religion, historical and geographical narratives. They exercise responsibility as forces for good or harm. Therefore, is objectivity obtainable or do exhibition strategies unknowingly promulgate propagandistic agendas? Traditionally an authoritarian approach was taken which assumed passivity to protect and preserve institutional authority by remaining aloof from competing values and views. Janes describes authoritarianism as a commitment to maintaining the status quo and collective obedience, drowning in unquestioned assumptions. Combined with widespread marketplace ideology, this hindered museums from embracing a deeper consciousness and recognizing their role as stewards, not spectators. ${ }^{125}$ Heumann Gurian asserts that museums endorsed social coercion, self-aggrandizement and propaganda. ${ }^{126}$ However, scholars now acknowledge that objectivity was never realistically obtainable. Social responsibility demands careful attention when raising impressionistic questions with highly complex answers. Do exhibitions reach a wide spectrum of learners? Do they incorporate multisensory and nonliterate modalities? Should they include divergent perspectives and who determines this? The Moesgaard Museum's exhibit of Grauballe Man is a good example of a multi-sensory, interactive approach which appeals to a wide range of people. It incorporates Lynnerup and Asingh's recent research and presents a range of

\footnotetext{
${ }^{124}$ Isabella Mulhall, personal conversation, August 9, 2019.

${ }^{125}$ Robert Janes, Museums in a Troubled World (New York: Routledge, 2009), 57.

${ }^{126}$ Elaine Heumann Gurian, Civilizing the Museum (London: Routledge, 2006), 69-71, 73-4.
} 
interpretations, which allows visitors to decide for themselves. Janes asserts that museums should exhibit cultures over objects as it is the cultural space between objects which instills them with meaning. ${ }^{127}$ However ideally, museums should exhibit both cultures and objects as objects allow us, at least in part, to understand that meaning. It is impossible to evade the fundamental responsibility to the public. Fortunately, disconnection between individual values and institutional organizations can be bridged through collaboration for the benefit of mutual growth. ${ }^{128}$ Manchester Museum's exhibition of Lindow Man illustrates this relationship clearly with its extensive consultation with special interest groups, particularly the Druid Network during its exhibition planning. Boyd illustrates that traditionally museums were perceived as places of objects when in fact they are places of ideas. The relationship is a cycle of generating human ideas which give rise to objects. Ideas are the principal means by which humans interact with objects in museums. ${ }^{129}$

\section{Museums and Controversy}

Movement away from traditional authoritarianism and toward diverse representation opens museums up to greater scrutiny. Differing ideas may lead to conflict rather than understanding. Ideas, knowledge and attitudes are continuously changing with improved research capabilities. Newer ideas contradict previously accepted truths. The British Museum's past reluctance to update their display of Lindow Man illustrates this tension. Museums are no longer perceived as infallible, presuming the privilege of unquestionable pronouncements. They are founded on the belief that conserving and exhibiting the material record of human activity is valued by all and an intrinsic social good. Presenting challenging and controversial perspectives in accordance with a democratic, free-thinking society is a key aspect of the museum's social responsibility. Harris asserts that any institution which deliberately avoids provocation becomes itself the subject of criticism. ${ }^{130}$ Yet controversy should be neither a criterion for nor hindrance to exhibition construction. Shifting social climates force curators to defend not only their exhibitions but the very principles which

\footnotetext{
${ }^{127}$ Janes, Museums in a Troubled World, 58.

${ }^{128}$ Janes, Museums in a Troubled World, 58.

${ }^{129}$ Williard Boyd, “Museums as Centres of Controversy,” Daedalus 128, no.3 (Summer 1999): 185-6.

${ }^{130}$ Neil Harris, "Museums and Controversy: Some Introductory Reflections," The Journal of American History 82, no. 3. (Dec. 1995): 1102-3, 1109.
} 
legitimize them. Curators should not seek to evade controversy but clearly define their exhibition goals. ${ }^{131}$ The NMI is a shining example of having a strong justification for their decisions, laid out plainly for the public. Walker Laird believes in museums' social responsibility to protest moral and political indignation against politicization in the preservation, discovery and use of historical evidence. ${ }^{132}$ Museums should have sound policies, clear exhibition goals, opportunities for visitor expression, updated interactive technology, and present diverse perspectives and research with a variety of available materials in the visitor resource center. The Manchester Museum provides a good model through its implementation of public lectures, symposia, debates, courses and performances as a platform for engaging in public discourse. All of these things cultivate a healthy space between museums and their public to process controversy, such as is presented with bog bodies. $^{133}$

\section{Social Responsibility and Public Discourse}

It is becoming increasingly vital for museums to participate consciously in the world around them. Museums require public support not only for continuity but to fulfill their underpinning foundational principal of improving quality of life. Janes asserts that as public institutions, museums are morally and intellectually obliged to challenge the status quo. ${ }^{134}$ They observe a function few other social institutions are imbued with the trust and credibility to fulfill. As part of this obligational functionality, museums must honor this trust and encompass openmindedness, particularly in the face of criticism. Consensus between museum professionals and audiences is unrealistic yet museums should serve as a platform for differing perspectives, even when it may be seen as politically correct pandering and naïve acceptance. Manchester Museum's exhibit of Lindow Man is a great example of this. ${ }^{135}$ But Boyd exhorts, if pursued genuinely, this generates a deeper understanding of a pluralistic society. The practice of consulting affinity groups raises the issue of how broad consultation should

\footnotetext{
${ }^{131}$ Janes, Museums in a Troubled World, 61, Harris, "Museums and Controversy," 1102-3, 1109.

132 Pamela Walker Laird, The Public's Historians," Technology and Culture 39, no.3 (Jul. 1998): 474, 481.

${ }^{133}$ Boyd, "Museums as Centres of Controversy," 203.

${ }^{134}$ Janes, Museums in a Troubled World, 172-3, 183.

135 Janes, Museums in a Troubled World, 172-3, 183.
} 
be. Curators should first consult with special interest groups before displaying remains and then weigh up opinion against their own professional discretion. ${ }^{136}$ In the case of bog bodies, many do not have any interest groups, thereby they obtain a collective responsibility. Still, negative reactions should not be startling, and accountability must be maintained in the case of repercussions. Nevertheless, museums should retain an open-mindedness and eagerness to engage and welcome challenges. Despite the average museum goer's general ignorance toward bog bodies, public feedback regarding how exhibitions are constructed and remains displayed have proved extremely useful for museum engagement. Consultation may uncover new insights and improve exhibition quality. It can help to improve diverse representation by highlighting conflicting perspectives which reflect a greater multiplicity present in a pluralistic democracy. Intellectual freedom is essential to museum integrity and must be resolutely supported and defended by curators. ${ }^{137}$

Bog bodies occupy a unique entanglement of museum and heritage ethics. From the ethics of disturbing and displaying human remains, to constructing suitable exhibits which incorporate diverse perspectives, they present a platform for healthy democratic debate surrounding the museum's role as social commentator. Their reach extends far beyond the bounds of archaeology as they penetrate the fabric of modern heritage and identity construction. The subsequent two chapters will more fully explore the concept of how identity is constructed through the textual analyses of an ancient case study (Tacitus' Germania) and a modern case study (Seamus Heaney's bog poems).

\footnotetext{
${ }^{136}$ Boyd, "Museums as Centres of Controversy," 187-8, 201-2.

${ }^{137}$ Boyd, "Museums as Centres of Controversy," 187-8, 201-2.
} 


\section{Tacitus' Germania: An Ancient Interpretation}

\section{Introduction}

The Germania of Tacitus is an important text in the study and reception of the bog bodies. Publius Cornelius Tacitus (c56-120CE) was a senator, orator, consul and historian of Rome during the Silver Age of Latin literature. The Germania (or On the Origin and Mores of the Germanic Peoples) written in 98CE, is an ethnographic text that purports to describe the communities inhabiting northern and eastern Germany, the Netherlands and southern Denmark. The first half (chapters 1-27) thematically considers the geography, climate, agriculture, political, social and militaristic organization while the second (chapters 28-46) composes a lively narrative of individual tribes. Many modern scholars such as Glob, Kelly, Aldhouse-Green and Ross have turned to Tacitus' Germania in order to reconstruct a meaningful context in which to situate the archaeological evidence for the bog people. The practice is understandable - the Germania relies on the experiences of travellers to northern Europe and on prior Greek and Roman ethnographic treatises, which also rely on autopsy. At the same time, although it has long been routine to regard Tacitus' account as a repository of more or less straightforward evidence which can be mined by way of positivist technique, recent research on Greco-Roman ethnography in general and on Tacitus specifically has demonstrated how complicated and difficult such texts in fact are. It is not simply that ancient accounts combine fact with fiction, but rather that the purposes to which ethnographic texts are put are manifold and ideologically centered. When the Romans, to focus on Tacitus and his predecessors, write about Gauls and Germans, their principal motive is not the composition of a dispassionate descriptive account. This is not to say that facts are unimportant to the Romans, even if they underestimate the difficulties inherent in recovering facts about foreign cultures from a limited number of informants, but rather that, when fashioning their accounts of foreign people - of "others" - they inevitably insert into their accounts a complex commentary on themselves. How this works itself out is never simple: Romans sometimes regard northern Europeans as a type of noble savage, uncorrupted by civilization; at others, a primal uneducated people whose urges and appetites remain untampered. Ethnographic texts become sites for contesting issues of gender, class, and 
cultural superiority - matters of strong disagreement even within Roman society. In other words, we now understand how many complications are entailed in trying to unpack a work like the Germania, about which even now there is no scholarly consensus. ${ }^{138}$ What is clear enough is the unsuitability of any methodology that simply picks and chooses material contained in the Germania without applying a close, even intense, degree of literary scrutiny.

This brings us to several Tacitean passages that have been adduced by some modern scholars in order to understand better certain features of the deaths of bog people. These are: the matter of ritualized human sacrifice (9.1) on account of their aristocratic, priestly status (7.1) possibly selected by lot (10.1) or on account of crime (12.1-2, 18.1/19.1-2) denoting concepts of shame and bondage (39.1-3) performed by night (11.1) in a sacred grove (39.1-3) as part of a ritual wedding to the goddess Nerthus (40.2-41). In what follows, I will look closely at these passages and suggest some of the ways in which they resist any straightforward application to the material evidence of the bog people.

\section{Translation and Commentary}

My own translation and commentary will seek to question the underlying assumptions of the interpretational narratives of bog bodies. It will question the foundational historical accuracy of these interpretations within a framework of literary translation.

\section{1-Authority of the Priests}

This passage in the context of kingship is related to the ideas of Glob and Kelly. In the first statement the rex (king) is chosen by nobilitas (noble birth) and the dux (general) by virtus (courage). This is an example of Romanization wherein Germanic mores have been

\footnotetext{
${ }^{138}$ Herbert Benario, "Tacitus' "Germania” and Modern Germany," Illinois Classical Studies 15, no.1 (Spring 1990): 163-6, Aldhouse-Green, Bog Bodies Uncovered, 34, 82, 88, Ellen O'Gorman, "No Place like Rome: Identity and Difference in the Germania of Tacitus" in Oxford Readings in Classical Studies; Tacitus, ed. Rhiannon Ash (Oxford: Oxford University Press, 2012), 96-7, Christopher Krebs, "The Continuing Message," History Today, September, 2011, 72.
} 
reconstructed within a familiar Romanized context or re-characterized as Roman, otherwise known as interpretatio Romana, fostering uncertainty whether this reflected genuine Germanic institutions:

Kings they select on the basis of their noble birth, generals on the basis of courage. Kings do not wield unlimited or unimpeded power and generals lead by example rather than by military authority. Their superiority depends on the admiration they earn when they exhibit energy and fight in the front ranks...

Anderson points out that Tacitus provokes readers' sympathy to compel understanding. The comparative element between Rome and Germania allows readers to comprehend the sentiment behind foreign institutions. The Germani become an ideal comparison as they mark the limits of Roman imperialism. ${ }^{139}$

Scholars such as Glob and Kelly argue for a tradition of sacred kingship but no evidence for this exists within classical texts. ${ }^{140}$ 'King' (German "konig") was borrowed by the west Germans from Scandinavian (old Norse "konungr"). It is now believed this was derived from "kona" (woman/wife), dubiously implying for Glob a fertility goddess.

No one is permitted to punish or bind or even to flog the soldiers except the priests. Nor is this carried out as if it were a penalty or by order of a general but rather on account of a command by their deity, who, they believe, aids them in war.

Breaches of discipline were regarded as sins against God and the punishment implied is expiatory sacrifice carried out by a priest. This interpretation is Tacitus' own in accordance with primitive belief. Rives suggests that priests were primarily keepers of the law which governed both secular and religious behavior, which Caesar contrasts to the Gallic Druids (Caes. Gal. 6.21). ${ }^{141}$

\footnotetext{
139 Tacitus, Germania, trans. J.C.G Anderson (Oxford: Oxford University Press, 1997), 9-13, 15-6, 27-30, 35, Tacitus, Germania, trans. J.B Rives (Oxford: Clarendon Press, 1999), 51-3, 55, Krebs, "The Continuing Message," 72.

140 Tacitus, Germania, trans. Rives, 144-5, Kelly, "Secrets of the Bog Bodies," 26-30, Kelly, "An Archaeological Interpretation," 237-9, Glob, The Bog People, 144-7, 152, 156, 159, 162-6, 190-2.

141 Tacitus, Germania, trans. Rives 150-1, Tacitus, Germania, trans. Anderson, 67-9.
} 


\section{1-Human Sacrifice}

Here Tacitus discusses the three chief gods (Mercury, Hercules and Mars) who were worshipped in the west but were not pan-Germanic:

Of all the gods they worship Mercury most especially...

This is a stock phrase or migratory motif used by Caesar of the Gauls (Caes. Gal. 6.17) and Herodotus (Her. Hist. 5.7) of the Thracian kings. Migratory motifs are transferred between peoples at similar developmental stages and are demonstrated through agreement in phraseology with both his Greek and Roman predecessors. Although many of Tacitus' sources have been subsequently lost, their content is indistinguishably woven into the fabric of the narrative. Caesar's Gallic War established the literary treatment of Germani and subsequent sources mimicked his model. This is true also for Tacitus who refers to Caesar as the 'Chief Authority.' However, it was likely Pliny's now lost 20 books of the Bella Germaniae was his main authority owing to Pliny's extensive personal experience as an officer on the Rhine from 46-58CE. These were supplemented with Livy's Histories, Aufidius Bassus' Bellum Germanicum and Velleius Paterculus' Historiae. Extensive contact also meant that some awareness of Germanic mores was commonplace. ${ }^{142}$

This section also reflects a romanization of Germanic gods. Each god is called by the Latin name with some aspect of the divine judged common to both, illustrating interpretatio Romana. Mercurius represents Wodan (Norse Othin/Odin). ${ }^{143}$ Thus, the Germani are Romanized (perceived in the likeness of Rome). It is widely held that Tacitus' intention is to erect a moral mirror to his compatriots in depicting an image of virtuous, unspoiled barbarians against the stark relief of a civilized Rome's blemishes. Thomas believes Tacitus' lack of verifiable observations and influence of ethnographic preconceptions make the Germania a virtually unusable historical source. Therefore, it must be read with careful evaluation and a willingness to acknowledge uncertainty. ${ }^{144}$

... and on set days they deem it pious to offer him human sacrifices.

\footnotetext{
${ }^{142}$ Tacitus, Germania, trans. Rives, 35, 37-8, Tacitus, Germania, trans. Anderson, 20-5, Richard Thomas, "The Germania as Literary Text," in The Cambridge Companion to Tacitus, ed. A.J Woodman (Cambridge: Cambridge University Press, 2009), 59, 61, Glob, The Bog People, 151, Benario “Tacitus' Germania” 163.

143 Tacitus, Germania, trans. Anderson, 73-4, Tacitus, Germania, trans. Rives, 156.

${ }^{144}$ Richard Thomas, “The Germania as Literary Text,” 59, 61, Tacitus, Germania, trans. Anderson, 9-13, 15-6.
} 
"On set days" is taken to mean the opening of spring, end of the harvest or possibly summer and winter solstices and may be compared to when the bog people were killed evidentially by their stomach contents. Here Tacitus first introduces human sacrifice. The wording denotes a civilized revulsion. For centuries the Romans attributed to barbarians the practice of human sacrifice as a manner of highlighting ferocity and perversion of proper religious norms. Caesar speaks this way of the Gauls (Caes. Gal. 6.16, 2-5) and Strabo claimed the Cimbri sacrificed their prisoners of war (Strab. Geo. 7.2.3). Rives believes there is good reason to think there is some truth behind the claims of human sacrifice by ancient authors due to the existence of votive deposits containing human bones alongside horses, pigs, cattle and sheep. However, here Tacitus is probably generalizing from some specifics. ${ }^{145}$

\section{1-Drawing by lot}

The process of Germanic lot taking is included in relation to Ross' suggestion that Lindow Man was singled out for sacrifice based on the scorched griddlecake found in his stomach, although her interpretation differs from Tacitus' explanation here of Germanic lot taking. ${ }^{146}$

They are extremely observant of auspicia and lots. The practice surrounding lots is simple. A branch is cut from a fruit tree which they divide into slips of wood. These they brand with certain marks and scatter them blindly, willy-nilly onto a white cloth. Next, if this consultation is a civic one, it is performed by a priest of the community, but if it is a private consultation it is performed by the head of the household, who after having prayed to the gods while gazing skywards, draws three separate slips.

The three shoots pertain to the mystical significance of the number three and the popular superstition that chance held significance in bringing luck. ${ }^{147}$

Then these are interpreted by the previously stamped mark. If the lots prohibit action, no further consultation takes place on that day - but even if they permit action, a further confirmation of the auspices is required.

\footnotetext{
145 Tacitus, Germania, trans. Anderson, 74, Tacitus, Germania, trans. Rives, 158-9.

${ }^{146}$ Anne Ross, The Life and Death of a Druid Prince, 13, 31-6, 39, 43, 45, 47, 49-50, 53, 58, 101.

147 Tacitus, Germania, trans. Anderson, 78-80.
} 
Rives points out the use of lots was also attested by Sidonis Apollinaris (Sid. Epist. 8.6.15) among the Saxons in selecting prisoners to sacrifice. ${ }^{148}$

\section{1-Theatrics/Ritual by night}

Here Tacitus discusses the auspiciousness of certain times and places. Meetings were usually held in consecrated places such as sacred groves, originally in connection with religious festivals in spring and autumn:

Unless some unexpected incident occurs, they gather on fixed days when the moon is neither new or full, for they believe this is the most favorable time to undertake a commencement of business. They reckon time not by day like us, but by night. This is how they define dates, this is how they fix dates. Night is seen to usher in the day.

Aldhouse-Green connects the sacredness of woods with wooded, swampy marshes and emphasizes the dangerous, mystical, fertile nature of the bog in connection with the extreme nature of the killings. She uses this to justify a re-enactment of human sacrifice as a theatrical religious night ritual despite the apparent lack of sacred woods here. In reality, Tacitus is describing Germanic tribal organization in terms of Roman civic tradition wherein he compares the Germani against the Romans. ${ }^{149}$ Therefore, to Tacitus the Germani are defined by their point of difference from their Roman counterparts, thus serving as a contrast.

\section{1-2-Bog Bodies}

This passage contains the most direct evidence of bog bodies.

At the assembly it is permitted to bring accusations and to level capital charges. There is a difference in punishment according to the crime. Traitors and deserters they hang from trees, the cowardly and unwarlike...

Firstly, the practice of hanging from trees was a form of expiatory sacrifice to Odin, wherein leafless trees were selected on account of being infelices (unlucky). ${ }^{150}$ Later references exist to hanging in sacrificial contexts. Orosius (Oro. Hist. 5.16.6) claims the Cimbri hung their captives after military victories as part of the destruction of general booty which he interprets

\footnotetext{
148 Tacitus, Germania, trans. Rives, 165-6.

149 Tacitus, Germania, trans. Rives, 168, 170, Tacitus, Germania, trans. Anderson, 84, Aldhouse-Green, Bog Bodies Uncovered, 35-8, 45, 49, 53, 82-3, 90, 92, 145, 197.

150 Tacitus, Germania, trans. Anderson, 87.
} 
as a sacrifice to Odin. Thus, scholars estimate deserters and traitors offended the god of war and were sacrificed similarly but the basis for this is uncertain. ${ }^{151}$ Furthermore Rives suggests that sacrificial hanging was part of a more complex ritual that occurred post-mortem which undermines the assumption that one of Lindow Man's possible causes of death was by hanging. ${ }^{152}$ Lastly, any evidence for sacrifice to Odin dates a millennium after Tacitus and lacks any connection to warfare. Tacitus also provides no clear evidence of a religious component.

....and those who bring their bodies into disrepute...

Corpores infames Anderson interprets as 'those addicted to unnatural vices' and Rives more specifically as a euphemism for pithacus or cinaedus, the passive sexual role which assumed inherent cowardice. The classical sources give conflicting information pertaining to the Germani's sexual proclivities (Quint. Maj.Dec. XVI 3.16). ${ }^{153}$ Later the Langobardic word 'Agra' (old Norse Argr) denoted an unmanly man, which indicates Tacitus' report may have reflected the practice of at least some Germani. ${ }^{154}$

...they submerge in the mud and the swamp with a wicker frame thrown over. Difference in punishment reflects the idea that wickedness ought to be publicly punished while shameful acts should be hidden.

This has been linked to a description of bog bodies since the $19^{\text {th }}$ century. The archaeological examples are plentiful and provide some corroboration for the use of bogs for ritualized killings and the weighing down of bodies. However, the contrasts between the archaeological record and Tacitus' report are striking. Drowning was an infrequent cause of death, dissimilar to Tacitus' implications. The majority were killed before submersion. Equally women and girls were also victims yet Tacitus refers to only men. Although there is no one archaeological example that corresponds exactly to his description, that does not prove Tacitus' description here completely unfounded as some of these elements have been observed in the archaeological record, such as the presence of wicker frames over victims. Tacitus cannot be expected to serve as an explanation for all due to the vast diversity in the

\footnotetext{
151 Tacitus, Germania, trans. Rives, 173.

152 Tacitus, Germania, trans. Rives, 172-3.

153 "The Germani know nothing [about homosexual activity]."

154 Tacitus, Germania, trans. Anderson 87, Tacitus, Germania, trans. Rives, 174-5.
} 
archaeological record. Furthermore, to know the extent to which Tacitus shaped this for his own purposes is elusive. More likely practices varied widely according to date, location and specific circumstances. ${ }^{155}$

\section{1/ 19.1-2-Marriage and Adultery}

The elevated rhetorical and expository style reflects Tacitus' admiration of German marriage and a desire to provoke sympathy among his readers. Comments of this kind regarding chastity are commonplace also in Caesar. ${ }^{156}$

However, marriage there is very serious. No other part of their customs could one praise more. For almost alone amongst barbarians they are content with a single wife...

The corrupting influence of shows and banquets upon women is often noted in a demoralizing sense as notorious opportunities for seduction. Here it exemplifies purity.

Therefore, they practice a highly protected chastity, corrupted by none of the enticements of spectacles or provocations of banquets.

He also remarks about clandestine love letters wherein illiteracy prevents the opportunity for immorality, presenting a lack of civilization as beneficial:

Men and women alike are ignorant of the secrets of letters.

In the case of adultery, punishment being in the husband's power mirrors Roman tradition which gave husbands the right to kill their wives caught in the act but it is not clear whether this was a reality. He attributes to the Germani customs closer to beliefs of early Roman practice than the Roman law of his own day and portrays them as upholders of a moral standard Romans themselves have abandoned:

Among such a numerous population there is very little adultery, the punishment for which is prompt and left to the authority of the husband: in the presence of relatives the husband expels her-stripped nude, hair hacked short-from the house and drives her

\footnotetext{
155 Tacitus, Germania, trans. Rives, 176.

156 Tacitus, Germania, trans. Anderson, 109, Tacitus, Germania, trans. Rives, 201.
} 
through the entire village while flogging her... Not by beauty nor age nor wealth will she find a husband.

... "As she might at Rome if she were a young, beautiful or rich adulteress."

Tacitus' description of shaving the adulterer's hair forms the basis for Glob's interpretation of the female bog bodies, in particular Windeby girl, whose hair appeared shorn. In her case, given she was only 14 at time of death (in addition to being recently identified as the wrong gender) whereas Germani tended to marry later, this is likely not adultery. Long hair served as an important indicator of social status marking free birth, a characteristically German trait. $^{158}$

O'Gorman believes the Germania is an exploration in search of the ideological Roman self. The Germani are depicted as noble savages, uncivilized and socially undesirable and thus represent a re-enactment of early Rome. O'Gorman thereby argues that Tacitus envisions Rome's decline from a morally upright past to its degenerate present. Yet the search for a return to early Roman values through an exploration of Germania is doomed as all this yields is a reflection of the Roman condition. The very exploration acknowledges the deRomanization of Rome, undermining the identity distinction which informs the text. ${ }^{159}$

For no one there laughs at vice, nor is seduction or corruption called 'the spirit of the age.'

Haynes suggests that the stereotypical Germanic tropes of a simplistic moral purity free from usury, avarice, fraud, trickery and prone to war derive from ideological structures that justify a superiority complex which translates into the Roman appropriation of "other" as a touchstone for self-identity. However, the text's deceptiveness lies in its reproduction of the "other" from a reflective distance. She believes "otherness" is conceptualized first figuratively and second in reality. The entire text serves as a fantasy of Rome alienated from its early self. In reality, Germania exerts an enormous force on the Roman political imagination on account of its inaccessibility and unconquerability. Haynes believes the text exposes the truth of Roman imperialism - "an expansionist system which cannot afford to

\footnotetext{
157 Tacitus, Germania, trans. Anderson, 113.

${ }^{158}$ Tacitus, Germania, trans. Anderson, 112, Tacitus, Germania, trans. Rives, 202-4.

${ }^{159}$ O’Gorman, "No Place like Rome,” 95, 102-3, 111-2.
} 
expand unless the emperor himself patrols the frontiers." ${ }^{160}$ Germania represents Rome's ideal of unconquerability and evokes the conqueror's fear of being conquered. Therefore, Germania as the mirror image of early Rome simultaneously both identifies with and divides Rome from itself as it can never go back to what it once was. She elaborates that the text is an account of Rome's desire to fix its identity by attempting to conceive of "otherness" but this becomes unobtainable when Germania cannot objectively be understood, and the text instead becomes an example of Roman misperception. She suggests that Rome is radically mistaken in what it recognizes as "other" as the "other" becomes synonymous with Rome itself and therefore paradoxically is no longer the "other." Therefore, Roman identity is founded upon a fantasy of what Rome perceives as "other" but in fact is only a reflection of the self. ${ }^{161}$

This section also provides a good example of how Tacitus' treatise is more construct than description. In contrast to Haynes, Gruen argues that the text cannot be reduced to the simplistic comparison between the virtuous Germani and reprobate Romans. Tacitus points equally to Germanic flaws as well as virtues and his descriptions are frequently accompanied by cynical comments. Although he proclaims their practice of monogamy praiseworthy, he favors a put-down of both societies. The language used to characterize female chastity is more indicative of a fenced-in modesty rather than a moral purity on the part of Germanic women. Thus, he believes that Tacitus sets the Germani and Romans on the same plane. ${ }^{162}$

\section{1-3-Shame and Bondage}

Aldhouse-Green's inclusion of this passage in Bog Bodies Uncovered pertains to her interest in the concepts of shame and bondage which she believes accompanies the deaths. ${ }^{163}$

At a pre-established time, all the tribes who share the same name and descent gather by way of delegations in a forest which is hallowed by ancestral auguries and sacred awe.

This is estimated to have taken place during the holy week at the end of September/start of October.

\footnotetext{
${ }^{160}$ Holly Haynes, “Tacitus’ Dangerous Word," Classical Antiquity 23, no.1 (April 2004): 34, 46-7.

${ }^{161}$ Haynes, “Tacitus' Dangerous Word,” 48-50.

${ }^{162}$ Erich Gruen, Rethinking the Other in Antiquity (Princeton: Princeton University Press, 2011), 159-61, 168-9.

${ }^{163}$ Aldhouse-Green, Bog Bodies Uncovered 35-8, 45, 49, 53, 82-3, 90, 92, 145, 197.
} 
After slaughtering a man on behalf of the community, they celebrate their primitive, horrendous, barbaric rites. And there are other acts of reverence associated with this grove. No one enters unless bound by chains like an inferior displaying the force of the divine. If he accidentally trips, he is not permitted to pick himself up but instead drags himself along the ground.

This report must be muddled as they would have been unable to perform the human sacrifice while shackled. Thus, either the festival took place outside of the grove or shackles were only worn on certain occasions, possibly as part of an ordeal or initiation or perhaps even were purely symbolic and non-restrictive.

Aldhouse-Green interprets sacrifice in light of Tacitean themes as having undercurrents of humiliation, abuse and denial of identity, implied by the sense of humility evident here: ${ }^{164}$

In that place all their superstition is centered, there their god is ruler of everything and the rest, subordinate and submissive.

The identity of the deity is contentious. Later the Swabians worshipped Tiu (identified as Jupiter) but he had not yet yielded supremacy to Odin, to whom alone human sacrifices were offered. Most likely Tacitus did not intend to suggest any specific god. Here rather, the most important observation is the sanctity of the grove. ${ }^{165}$

\section{2-41-Nerthus}

This passage describes the formed religious union for the worship of Nerthus and serves as the basis for Glob's interpretation of the fertility goddess' wedding despite the fact that this is the only information we have on the cult.

And the Reudgni and Aviones and Anglii and Varini and Eudoses and Suarines and Nuitones are protected by rivers and woods. There is nothing notable about them individually except together they commonly worship Nerthus, who is Mother Earth. And they believe she intervenes in human affairs and rides among the peoples.

Tacitus likens Nerthus to Terra Mater, the source of all life and giver of fertility. Glob extrapolated from this description the cycle of the sacred spring wedding, symbolizing the

\footnotetext{
164 Tacitus, Germania, trans. Anderson, 182, Tacitus, Germania, trans. Rives, 288, Aldhouse-Green, Bog Bodies Uncovered 35-8, 45, 49, 53, 82-3, 90, 92, 145, 197.

${ }^{165}$ Tacitus, Germania, trans. Anderson, 183-4, Tacitus, Germania, trans. Rives, 289.
} 
union between earth and sky. Kelly elaborates on this by suggesting the identity of the groom were deposed kings, with sacrifice as the central function of the kingly marriage to the earth goddess. Marriage rites were not uncommon among fertility cults but Tacitus makes no mention of it. ${ }^{166}$

There is on an island in the ocean a sacred wood and in this is a consecrated wagon, concealed by a cloth. Only one priest is permitted to touch it. He senses when the goddess is present within the wagon and with veneration escorts her as she is borne in the wagon, which is drawn by cattle. Days of rejoicing follow and festivals are held at whatever places she deems worthy to receive and entertain her. They do not wage war, they do not take up arms, every piece of iron is shut away. Peace and tranquillity are known and loved only at that time, until the same priest returns the goddess to her sacred precinct once she is sated with the association of mortals.

Tacitus' reliability is brought into contention, raising the suspicion of his borrowing particular aspects of this cult by its heavy similarities to Demeter, Magna Mater and Asia Minor goddess Cybele, introduced to Rome in 204BCE. The main feature of Cybele's cult is a procession of the goddess in a cattle-drawn chariot, a symbol of fertility. As an almost exact reproduction, it has been suggested that Tacitus was only able to confirm the name of the goddess while the description is entirely invented. The name "Nerthus" is philologically identical to the Norse god Njord, god of fertility and prosperity while her functions are attributed to Njord's son Frey, who procured a bride who accompanied him in his chariot. This raises the issue of gender in that perhaps Tacitus assumed the role of a fertility deity was female. However, Rives states that there is no reason to believe Tacitus did not have access to some account of the cultic rites as there are several unique elements in his description such as the sacred grove, the goddess' travels, the accompanying periods of truce and the drowning of the slave attendants. He is confident some aspects of this cult existed, but it is difficult to ascertain which are filtered through interpretatio Romana. ${ }^{167}$

Gruen also points out that Tacitus makes apparent the distinctions between the Germani and Romans as much as Tacitus does their similarities. For example, the religion of the Germani was aniconic. Their gods are not likened to any human form. Therefore, his intentions evade

\footnotetext{
166 Tacitus, Germania, trans. Anderson, 185, 187-8, Tacitus, Germania, trans. Rives, 292, Kelly, "An Archaeological Interpretation,” 237-9, Glob, The Bog People, 144-7, 152, 156, 159, 162-6, 190-2.

167 Tacitus, Germania, trans. Rives, 292-4, Tacitus, Germania, trans. Anderson, 187-8.
} 
reductionistic comparisons. Here he comments on Germanic religion but refrains from either praise or judgment. Tacitus does not seem to perpetuate the maintained stereotype of unsophisticated primitivism. This signals that even with different cultural mores, Germanic culture may still be understood in terms applicable to Romans. Thus, he intends each to reflect on the other rather than to underscore Germanic "otherness." Gruen believes that for Tacitus, irony trumps ideology. ${ }^{168}$

Then the wagon and cloth and if you believe it, the divinity herself are purified by washing in a secret lake. Slaves perform this service and are immediately swallowed by the same lake. This breeds a mysterious fear and sacred ignorance because what takes place is witnessed only by those about to die.

Tacitus likely assumes the slaves are killed on account of human contact with the divine, thus Nerthus is purified from human contact. Anderson points out that this lavation image occurred also for Cybele on March $28^{\text {th }}$ although the real purpose supposedly was to induce rain. The sacrifice here is expiatory, but also to ensure secrecy. ${ }^{169}$

Tacitus' use of migratory motifs and interpretatio Romana creates a conscious bias which negates the possibility of historical accuracy.

\section{Conclusion}

Many modern scholars such as Glob, Kelly, Aldhouse-Green and Ross have relied upon the historical accuracy of Tacitus' Germania to answer questions empirical evidence alone cannot. They have looked to various Tacitean passages to justify their preconceived notions and adjusted the evidence to fit their theories. These involve ritualized human sacrifice (9.1) possibly selected by lot (10.1) on account of their aristocratic, priestly status (7.1) or having committed some crime (12.1-2, 18.1/19.1-2), denoting concepts of shame and bondage (39.13) performed by night (11.1) in a sacred grove (39.1-3) and as part of a ritual wedding to the goddess Nerthus (40.2-41). Despite the fact that Tacitus makes none of these connections, his historical accuracy must be called into question if he is to be used as a historical source.

\footnotetext{
${ }^{168}$ Gruen, Rethinking the Other, 175-8.

169 Tacitus, Germania, trans. Anderson, 190.
} 
Tacitus' intention is to comment on the morality of his own contemporary society using Germania as a basis for comparison by creating an analogy of Germania as a metaphorical representation of Rome's earlier history. Tacitus employs ethnographic generalizations, evident in his usage of migratory motifs, to drive the narrative. This results in the homogenization of vast cultural diversity to a pan-Germanic grouping, undermining historical accuracy. Therefore, Thomas declares him a virtually unusable historical source. Rives asserts that Tacitus' intention is to expose the limitations of Roman imperialism. Haynes believes the Germani represent Rome's ideal of unconquerability and thus Germania becomes a fantasy dreamscape of Rome itself. By contrast, Gruen believes Germania does not reflect a mirror image of Rome's early history but asserts instead that Tacitus weighs each culture against the other respectively to employ an understanding of each in relation to the other. Conceptualization of the "other" in relation to the self has been further explored by Seamus Heaney in his bog poems. This will be discussed in the following chapter. To Glob, Kelly, Aldhouse-Green and Ross Tacitus has uncritically become the foundational narrative for their interpretations of the bog bodies. Therefore, his lack of historical accuracy and heavy bias becomes imperative. The Germania does not provide a kind of Rosetta Stone for the unclear archaeological evidence for bog people owing to its literary and ideological difficulties. 


\section{Seamus Heaney's Bog Poems: A Modern Interpretation}

\section{Introduction}

\section{Early Life}

Born in 1939 in County Derry, Northern Ireland on his family's cattle farm as the eldest of nine (seven boys, two girls) to Patrick and Margaret Heaney, Seamus' childhood was preelectric, horse-drawn carts, outdoor toilets and no running water. He viewed the world through a Catholic milieu of miracular symbolism, ritual and contemplation. The conflict between Heaney's desire for artistic solitude and the lure of communal intimacy stemmed from his large familial upbringing within a cohesive catholic minority. He developed a distinctive ecumenism whilst attending a mixed Protestant-Catholic school. His poetry is embedded with lamentations of his ebbed away sheltered 1940s rural childhood and a subsequent longing for a return to stable values and traditions. St Columbs School instilled in him a passion for the English classics such as Keats and Hopkins. This persisted at Queen's University, Belfast in 1957 (where he graduated with first-class in English literature) and at St Joseph's Teachers Training in 1962 where he was introduced to Kavanagh, John Hewitt and Ted Hughes. He spent 1962-3 teaching at St Thomas' intermediate but decided to pursue higher academia after being exposed to Philip Hobsbaum's Belfast group of writers. He then took up a lecturing post at Queen's University. Heaney published Death of a Naturalist in 1965 but confirmed his reputation with Door into the Dark in 1969 which featured the first bog poem "Bogland." Both are characteristically defined by their strength in their exact, evocative descriptions. Although they contained some political echoes, no real political consciousness appears until Wintering Out (featuring "The Tollund Man" and "Nerthus") published in 1972 and North (featuring "Come to the Bower," "Bog Queen," "The Grauballe Man," "Punishment," "Strange Fruit" and "Kinship") published in 1975 and written during one of the most violent periods of Irish history. Anglophobia peaked among Catholics in the aftermath of Bloody Sunday. ${ }^{170}$ Increasing tensions spiraled into violent

\footnotetext{
${ }^{170}$ On January $30^{\text {th }} 1972,13$ people were killed while peacefully protesting the internment of suspected IRA members without trial.
} 
factionalism between the provisional IRA and protestant paramilitaries such as the Ulster volunteer force. Torn between Catholic allegiance and poetic independence, Heaney left for Berkley University in 1970 and returned to Belfast in 1971. After a bomb exploded meters away from his wife Mary in the street and he received multiple death threats following the airing of a documentary about him, Heaney then left for Glanmore, County Wicklow. The Troubles provoked his pursuit of adequate symbols to describe the predicament. ${ }^{171}$

\section{Style and Influence}

Spanning three decades during one of the most tumultuous periods of Northern Ireland, Heaney established himself as a poet steeped in history. He transformed his obscure rural background into pastoral verse and positioned himself as an international figure. Supremely concerned with $20^{\text {th }}$-century sufferings and attuned to man's capacity for depravity, he relentlessly affirmed joy through solidarity. This led to his Nobel Prize win in 1995 "for works of lyrical beauty and ethical depth which exalt everyday miracles and the living past." ${ }^{172}$ He received several major writer awards including the Griffin Trust's lifetime achievement award in 2012. Heaney died on August $30^{\text {th }}, 2013$ due to heart complications a week before scheduled surgery. His poetry continues to outsell all others in Faber by 10:1 and he is included in anthologies and school curriculums internationally. His legacy prevails through his environmental commitment and his conviction in human value and the power of language. Following his death, he was exalted as a genius and man of the people whose generosity, amplitude and sympathy characterized his dealings on every level. His work is an example of integrity, deep natural engagement and language's signifying power of hope. ${ }^{173}$

\footnotetext{
${ }^{171}$ Richard Rankin Russel, Seamus Heaney; An Introduction (Edinburgh: Edinburgh University Press, 2016), 614, Ian Hamilton, Jeremy Noel-Tod, The Oxford Companion to Modern Poetry (Oxford: Oxford University Press, 2013), 256-7.

172 Allison Carruth, "On Bog Lands and Digital Markets: Seamus Heaney’s Recent Poetry," Pacific Coast Philology 46, no.2 (2011): 233, Rankin Russel, Seamus Heaney, 4-5, 19-20, Jay Parini, “The Bog Poet” The Nation, January 4, 1999, 25, 28.

${ }^{173}$ Rankin Russel, Seamus Heaney, 3-4, 19-24, 26.
} 


\section{The Bog Poems}

\section{Door Into The Dark}

Door into the Dark is Heaney's introduction to the bog as the physical archive of Irish history. Yet the metaphor of the bog as an archive, still here in its earliest stages, follows on from Death of a Naturalist wherein a young Heaney is searching for the meaning of his own poetic existence as he diverts from his familial occupation of farming into literature. His pen is the spade with which he digs into the bog just as his father did before him.

\section{"Bogland"}

In this, the first of the bog poems, Heaney discovers in the bog a symbol of communal identity and cultural memory tainted with communal violence:

Our pioneers keep striking

Inwards and downwards,

Every layer they strip

Seems camped on before.

The bogholes might be Atlantic seepage.

The wet centre is bottomless. ${ }^{174}$

The first-person plural pronouns are confiding and suggestive of commonality. $\mathrm{He}$ consistently returns to the metaphor of digging into a vertical horizon. The bottomlessness grants a terrifying glimpse of the elusiveness of self-definition. "Bogland" concludes Door into the Dark but represents a new beginning, venturing into the poet and nation's bottomless history. It initiates the process of a much riskier, tentative and exploratory self-commentary. Corcoran describes it as a "disconcerting instance of metaphorical and syntactical

\footnotetext{
${ }^{174}$ Seamus Heaney, Door Into the Dark (London: Faber and Faber, 1969), 55.
} 
reflexivity." 175 Heaney is establishing the foundation for using the metaphor of the bog as a basis for maneuvering Northern Ireland's identity crisis.

\section{Wintering Out}

The agricultural term "wintering out" denotes withstanding a harsh winter and has connotations of pre-imperial, indigenous Ireland. Wintering Out explores the underlying structures of present hostilities through the uncovering of both linguistic and territorial dispossession. Heaney's tone throughout was construed by his critics as indifference through either lacking any political engagement whatsoever or as an acknowledgment of the political situation, but not addressing it. Corcoran notes Heaney's dilemma- if Heaney addressed the violence, he was accused of exploiting suffering but if he ignored it, he was guilty of an ivory tower of indifference. However, Corcoran believes Wintering Out displays a peculiar charge and vibrancy of a poet discovering his unique identity. ${ }^{176}$

\section{"The Tollund Man"}

Glob's dramatic and densely figurative descriptions inspire the subject matter of this poem and give shape to Heaney's poetic response in an intertextual dialogue. There is a neoromantic poetic connection to Tollund Man in the strong sense of recognition with him as if he were an ancestor or an old, moustached uncle. Thus, he is translated into an archetype.

Throughout section I Tollund Man exhibits but also transcends violence. Heaney assimilates the foreign smells and sights into his own cultural and spiritual landscape. The earlier pentameter is reduced to monosyllables in the opening stanza, relying on alliteration, assonance and consonance for rhythmic integrity:

Someday I will go to Aarhus

To see his peat-brown head,

\footnotetext{
${ }^{175}$ Neil Corcoran, The Poetry of Seamus Heaney; A Critical Study (London: Faber and Faber, 1998), 19-20, Rankin Russel, Seamus Heaney, 53-4, John Dennison, Seamus Heaney and the Adequacy of Poetry (Oxford: Oxford University Press, 2015), 54, Daniel Tobin, Passage to the Center; Imagination and the Sacred in the Poetry of Seamus Heaney (Lexington: University of Kentucky Press, 1999), 66.

${ }^{176}$ Corcoran, The Poetry of Seamus Heaney, 28.
} 
The mild pods of his eye-lids,

His pointed skin cap.

The vowels here meditate on an unearthed symbolic corpse. This represents the socially restorative function of the poet in imaginatively re-vitalizing the corpse. Heaney's immediate attraction to Glob's The Bog People was strongly visual in nature. When he fulfilled his pilgrimage to see Tollund Man in the Silkeborg Museum in 1973, Heaney remained drawn to him by what he interpreted as the coalescence of beauty and atrocity embodied by Tollund Man's brutal death yet peaceful expression which Heaney believed redeemed Tollund man from just a brutal violence victim, humanizing him. ${ }^{177}$

In the third stanza of section I his ambiguity demonstrates his resistance to celebrating violence and he expresses religiosity by portraying Tollund Man as a secular saint:

She tightened her torc on him

And opened her fen,

Those dark juices working

Him to a saint's kept body,

The torc recalls Tollund's noose and provides an archaeological link to the Celts, Saxons and Vikings, unifying their allegiance to Nerthus and expanding the circle of violence from Jutland to Ireland. Like the uncorrupted bodies in Catholic hagiology, Tollund Man becomes a Christ-like saintly intercessor as a fertility sacrifice to the goddess, sacralizing the deification of an innocent victim. In establishing links between Tollund Man and on one hand the Irish Celts and Vikings and at the same time on the other the Irish Catholics, Heaney assumes the conviction of trans-historic and religious continuities between Glob's fertility cult and Northern Irish Catholicism. As Heaney builds his mythopoetic constructs between Jutland and Ireland, he skilfully interweaves Tollund Man's death with sectarian atrocities throughout the text.

\footnotetext{
${ }^{177}$ Rankin Russel, Seamus Heaney, 62-5.
} 
In section II the mythopoetic links are expanded on as Tollund Man is reduced to a repository archetype. Heaney therefore folds Christian creeds into the same cycle of violence. He projects 'own' (Irish Catholicism) onto "other" (Tollund Man and the cult of Nerthus) and blurs the distinction between god and death as the poet's prayer germinates further violence in the first stanza of section II: ${ }^{178}$

I could risk blasphemy,

Consecrate the cauldron bog

Our holy ground and pray

Him to make germinate.

He is willing to risk blasphemy in replacing traditional Christian icons with Tollund Man and the bog. He wants to consecrate the land into holy ground by transforming the victims into hope just as Tollund Man's killers hoped his death would germinate next season's seeds. This extends hope for transformation and renewal. Corcoran believes the connection is not between Jutland/Ireland but Tollund/poet through the poet's sympathetic relationship with Tollund. However, Hart asserts the poet's optimistic intimacy with Tollund Man is displaced as he recognizes both his responsibility to and distance from the "other" which destabilizes the stanza. ${ }^{179}$

In section III deference and ambiguity cast aside the previous section's favor of religiously sanctioned practices stemmed from unassailable convictions. The Yeatsian recitation of names in the second stanza of this section is a synecdoche of continuity which overrides the alienation of not knowing their tongue: 180

\footnotetext{
${ }^{178}$ Dennison, Seamus Heaney, 53-4, 59, Michael Parker, "Gleanings, Leavings: Irish and American Influences on Seamus Heaney's 'Wintering Out' 1972," New Hibernia Review 2, no.3 (Autumn, 1998): 23-4, Caleb Caldwell, "Joy in Night: Witness and the Limits of Discourse in Seamus Heaney's North," Religion \& Literature 45, no.1 (Spring, 2013): 118, Floyd Green Collins, "Seamus Heaney: The Crisis of Identity" (PhD diss., University of Arkansas, 1997), 73-4.

${ }^{179}$ Caldwell, "Joy in Night," 118, Andrew Foley, "Befitting Emblems of Adversity: The Bog Poems of Seamus Heaney," English Studies in Africa 41, no.1 (1998): 64-5, Henry Hart, "Poetymologies in Seamus Heaney's Wintering Out," Twentieth Century Literature 35, no. 2 (Summer, 1989): 332.

${ }^{180}$ Corcoran, The Poetry of Seamus Heaney, 33-7.
} 
Tollund, Grauballe, Nebelgard,

Watching the pointing hands

Of country people,

Not knowing their tongue.

Out here in Jutland,

In the old man-killing parishes

I will feel lost,

Unhappy and at home. ${ }^{181}$

The question of feeling at home in the last stanza demonstrates a reterritorialization as Heaney envisions Jutland as a homogenous and undifferentiated land from his own. ${ }^{182}$ The paradoxical concluding lines make the poet both estranged and familiar. 'Home' moves beyond irony into discomfort and desolation, hitting a painful tone of personal incomprehension, isolation and pity. His imagined parallels between Ireland and Jutland signal Heaney's development of poetry's social function in realizing a restorative connection to a unifying communal identity. However, Dennison asserts the problematic nature of this derives from its emergence coinciding with Heaney's increasing preoccupation with temporality and his pessimistic view of his own reality. There is a problematic disjunction between his search for 'befitting emblems of adversity' and the continuity of cultural memory at odds with temporality. ${ }^{183}$ Dennison believes Heaney's illustration of the cultural continuation of violence risks rationalizing violence through its exploratory function which may be construed as sympathetic justification. ${ }^{184}$ However, Rankin Russel asserts Heaney

\footnotetext{
${ }^{181}$ Seamus Heaney, Wintering Out (London: Faber and Faber, 1972): 36-7.

${ }^{182}$ Rankin Russel, Seamus Heaney, 62-5, Hart, "Poetymologies,” 333.

${ }^{183}$ Heaney uses the Yeatsian term 'befitting emblems of adversity' to describe his search for symbols to help him convey the underlying cause of the Troubles.

${ }^{184}$ Dennison, Seamus Heaney, 55.
} 
does not justify violence but instead memorializes it by imagining himself into the landscape. He appears torn between his two separate identities of publicly a Catholic Nationalist and privately a poet. ${ }^{185}$

\section{"Nerthus"}

In his second poem of Wintering Out Heaney introduces female sexuality and fertility represented by the figure of Mother Earth:

For Beauty, say an ash-fork staked in peat,

Its long grains gathering to the gouged split;

A seasoned, unsleeved taker of the weather... ${ }^{186}$

His vividly literal description invokes numerous archaeological examples of supposed fertility figures discovered in bogs (see figure 2). ${ }^{187}$

\section{North}

In North Heaney more fully explores the racialized identity of Northern Irish Catholics. Its two halves constitute two forms of symbolic and explicit urgency, drawing heavily on Iron Age myth inspired by Glob's The Bog People. The first section traces historic invasions while the second establishes the bog victims as the metaphorical framework within which to contextualize contemporary Irish identity. The bog poems raise questions concerning guilt and complicit involvement. On account of this they have been accused of offering a sympathetic explanation for and granting historic respectability to sectarian violence. ${ }^{188}$ More recent criticism has focused on gender and voice in the bog poems. Heaney extrapolates the

\footnotetext{
${ }^{185}$ Rankin Russel, Seamus Heaney, 66, 68, 71, Corcoran, The Poetry of Seamus Heaney, 33-7.

${ }^{186}$ Heaney, Wintering Out, 38.

187 “Nerthus," Fawbie, accessed Jan 24, 2020, https://fawbie.info/wintering-out/nerthus/

${ }^{188}$ Foley, "Befitting Emblems of Adversity," 70-1.
} 
myth of Glob's fertility goddess to incorporate Mother Ireland who is personified by the bog itself. ${ }^{189}$ Coughlan shows Heaney's function of the feminine to be the vehicle of myth and passage of memory. She possesses a hidden knowledge coveted by the male poet. The poet's self-discovery therefore entails the defeat of the feminine. Gender politics merge with politics of place whereupon Mother Ireland becomes a demonstration of Catholic republican tribalism who makes martyrs of her sacrifices. ${ }^{190}$ Heaney's politics of place seeks to explore the underlying psychology of violent perpetrators in order to understand present hostilities. He encourages an embrace of "otherness" by evoking empathy toward their dead. The act of empathizing with difference holds the power to break the violent cycle of ideological factionalism. All the while he remains aware of his own imaginative construction of historical myth in building modern Irish identity. ${ }^{191}$

\section{"Come to the Bower"}

In the first of the bog poems in North Heaney conflates the role of the poet with an archaeologist uncovering a sacrificial corpse:

To where the dark-bowered queen,

Whom I unpin,

Is waiting. Out of the black maw

Of the peat, sharped willow

Withdraws gently.

\footnotetext{
${ }^{189}$ Foley, "Befitting Emblems of Adversity," 62-3.

${ }^{190}$ Coughlan, "Bog Queens: The Representation of Women in the Poetry of John Montague and Seamus Heaney," in Seamus Heaney, ed. M. Allen (London: Palgrave Macmillan, 1997), 188, 200.

${ }^{191}$ Bernard O’Donoghue, "Introduction," in The Cambridge Companion to Seamus Heaney, ed. O’Donoghue (Cambridge: Cambridge University Press, 2008), 2-6, Hamilton, Noel-Tod, The Oxford Companion, 256-7, Richard Rankin Russel, “The Black and Green Atlantic: Violence, History and Memory in Natasha Tretheway's "South" and Seamus Heaney's "North," The Southern Literary Journal 46, no.2 (Spring, 2014): 159, Brian McHale, “Archaeologies of Knowledge: Hill's Middens, Heaney's Bogs, Schwerner's Tablets," New Literary History 30, no.1 (Winter, 1999): 243, Tim Hancock, "Daring to Make Free: Seamus Heaney and the Ulster Politics, 1968-1979,” English 47 (Summer, 1998): 114, Rankin Russel, Seamus Heaney, 15-7, 55, Tobin, Passage to the Center, 70.
} 
I unwrap skins and see

The pot of the skull,

The damp tuck of each curl...

...I reach past

The riverbed's washed

Dream of gold to the bullion

Of her Venus bone. ${ }^{192}$

The disturbing sexual imagery draws on notions of renewal interlinked with hints of political revolution and transformation. The unpinning symbolizes female disempowerment which escalates in his later poems and climaxes in "Punishment." The tone is one of uncomfortable exposure as the poet unwraps the body, forcing the reader to observe the violation of crossing the boundary between the dead and the living. Contextualized within implications of necrophilia and disempowered female sexuality, the bog enacts firstly death and then rebirth. The male poet briefly inhabits a state of fascination in a fleeting resistance but is unable to access the bog's power. ${ }^{193}$

\section{"Bog Queen"}

Heaney's metaphor of the bog as a vagina dentata, previously introduced in "Tollund Man," is further developed as simultaneously a birthing and consumption. This poem is written from the perspective of a supposed Viking Queen whose body was discovered on the Moira estate in Belfast in 1781. Her Viking heritage alludes to the title North. A Danish corpse on Irish turf validates Heaney's mythic connection:

My body was braille

For the creeping influences...

\footnotetext{
${ }^{192}$ Seamus Heaney, North (London: Faber and Faber, 1975), 24.

${ }^{193}$ Foley, "Befitting Emblems of Adversity," 66-7, Stephanie Alexander, "Femme Fatale: The Violent Feminine Pastoral of Seamus Heaney's North," The Canadian Journal of Irish Studies 39, no.2 (2016): 226-7, Patricia Coughlan, "Bog Queens," 194.
} 
My diadem grew carious,

Gemstones dropped

In the peat floe

Like the bearings of history.

...which they robbed.

I was barbered

And stripped

By a turf cutter's spade...

....and I rose from the dark,

Hacked bone, skull-ware,

Frayed stitches, tufts,

Small gleams on the bank. ${ }^{194}$

Her native authority is symbolized by the diadem but is gradually undermined throughout the poem. There is a delicate depiction of decay and the passing of geological time as the body is reclaimed and becomes the land. In contrast, her removal from the land and rising from the dark marks her as a symbol of indigenous resentment and political revolution.

Her both unapologetically powerful and fragile corporality invokes the IRA hunger strike protests of the Long Kesh prisoners. ${ }^{195}$ The use of the feminine in service of the male fantasy becomes apparent through the masculine penetration by the spade. In life she was a victim of tribal violence but in death she is cast as the victim of English colonizers destroying the environment. Borrowing her voice, he raises questions of authority and agency. Interestingly

${ }^{194}$ Heaney, North, 25-27.

${ }^{195}$ Many of the prisoners held at Long Kesh were suspected of terrorist activities but imprisoned without trial. In 1980-81 republican prisoners led by Bobby Sands protested for political status. 10 prisoners died. 
he bestows voice to no other bog victims in his poems. However, her privileged position adds authority to her voice as he wrestles with his own patriarchal guilt. ${ }^{196}$

\section{"The Grauballe Man"}

The poem begins with subjective expressions composed of similes with metonymically related objects rather than full-fledged metaphors but eventually shifts into metaphoricity:

The cured wound

Opens inward to a dark

Elderberry place...

And his rusted hair,

A mat unlikely

As a foetus.

I first saw his twisted face

In a photograph,

A head and shoulder

Out of the peat,

Bruised like a forceps baby...

The sequential listing of features undoes the body which is unable to assume totality. The meaning becomes fragmented as adjectives become the subject, negating an accurate portrait. He is constructed almost entirely of similes which constantly shatter any fixed image. Their accumulation is destabilizing as the metaphor moves from known to unknown. The poem resembles "The Tollund Man" in its vivid descriptions and imagery of renewal

The cured wound ironically invokes preservation and healing, opening inwardly to an elderberry place like a vaginal opening to an earthly womb. The body becomes the bog and

\footnotetext{
${ }^{196}$ Fran Brearton, "Heaney and the Feminine," in The Cambridge Companion to Seamus Heaney, ed. O'Donoghue (Cambridge: Cambridge University Press, 2008), 77, Foley, "Befitting Emblems of Adversity," 67, Alexander, "Femme Fatale," 228-30, Collins, "Seamus Heaney: The Crisis of Identity" 94-5, Corcoran, The Poetry of Seamus Heaney, 70.
} 
the bog a vagina. Fertility is further evoked by the fetus imagery inspired by Glob's photography (see figure 3 ) and his emergence out of the bog is a second birth.

On his shield, with the actual weight

Of each hooded victim

Slashed and dumped. ${ }^{197}$

The double exposure effect in the overlapping of Ulster over the Iron Age is minimal but appears both in the closing stanza's 'hooded victims' and in the previous remark regarding elderberry. This is a link to the Irish lore of Christ's elderberry wooden cross and further reinforces Catholic and Iron Age religiosity. Reverie is interrupted by brutal death and modern murder. The word 'actual' rebuts a glossing over of the moral implications. Heaney's poetic self-consciousness demonstrates his anxiety in addressing human suffering as exemplified by the intimacy between beauty and atrocity. Both "The Grauballe Man" and "Punishment" explore ambiguous responses weaved into precise, meticulous metaphors. This poem cultivates a perfect atrocity which glorifies death for the sake of myth in a bid to illustrate the process behind nationalist blood feuds. The anonymity of the bog victims gives Heaney an imaginative scope which he would not have been able to assume in a retelling of local assassinations. Tobin believes "The Grauballe Man” desymbolizes itself by exposing complicity in violence and blindness toward atrocity. ${ }^{198}$

\section{"Punishment"}

The subject of the poem is Windeby Girl, originally believed to have been sacrificed owing to her sexual deviancy. Her shaved hair, evidence of her adultery, is derived from Glob's interpretation of Tacitus' chapter 19, mentioned in the previous chapter: ${ }^{199}$

I can feel the tug

\footnotetext{
${ }^{197}$ Heaney, North, 28-9.

${ }^{198}$ McHale, "Archaeologies of Knowledge,” 243-5, Foley, "Befitting Emblems of Adversity," 68, Caldwell, "Joy in Night," 119-20, Collins, "Seamus Heaney: The Crisis of Identity," 97, Tobin, Passage to the Center, 120, Corcoran, The Poetry of Seamus Heaney, 59, 71, Alexander, "Femme Fatale," 222-4, Helen Vendler, Seamus Heaney (London: Fontana Press, 1998), 35.

199 See page 80.
} 
Of the halter at the nape

Of her neck, the wind

On her naked front.

It blows her nipples

To amber beads,

It shakes the frail rigging

Of her ribs...

Her shaved head...

Her blindfold a soiled bandage

Her noose a ring

A dark, disturbing tone permeates this poem as it recreates the victim's frail beauty in precise sexual detail. Despite professing empathy, it slips rapidly into objectification of the silenced female victim. Rankin Russel identifies the risk of voice disappearing as a male poet empathizes with a female victim. ${ }^{200}$

In this poem Heaney wants to correct his previous tendency to venerate the bodies so he addresses the "little adulteress" directly:

Little adulteress,

Before they punished you...

Your tar-black face was beautiful,

My poor scapegoat,

I almost love you

${ }^{200}$ Rankin Russel, Seamus Heaney, 75-6, 79. 
But I would have cast, I know,

The stones of silence.

I am the artful voyeur

Of your brain's exposed

And darkened combs,

And your muscles' webbing

And all your numbered bones

Intertextually woven are the biblical allusions of the scapegoat of Leviticus 16, the numbered bones of psalm 22.17, and the adulteress of John 8.1-11, once again further cementing the link between Iron Age Jutland and Irish Catholicism. He casts himself as an artful voyeur watching on at the stoning of the adulteress in John. ${ }^{201}$ She is publicly shamed as David describes in Psalm 20 and is compared to Aaron's scapegoat in Leviticus. ${ }^{202}$ Here the poet's empathetic pity confirms his own self-conviction. For this he has been criticized as assuming a safely removed stance.

I who have stood dumb

When your betraying sisters,

Cauled in tar,

Wept by the railings,

Who would connive

\footnotetext{
${ }^{201}$ John 8.7 "If any one of you is without sin, let him be the first to throw a stone at her." The Holy Bible, New International Version (Minto: The Bible Society in Australia, 2008), 755.

202 Psalm 20:17 "I can count all my bones; people stare and gloat over me." Leviticus 16.21 "He is to lay both hands on the head of the live goat and confess over it all the wickedness and rebellion of the Israelites-all their sins-and put them on the goat's head." The Holy Bible NIV, 87-8, 391.
} 
In civilized outrage

Yet understand the exact

And tribal, intimate revenge. ${ }^{203}$

There are three immoral acts detailed in the poem; First, silent complacency while public punishment takes place, secondly conniving in hypocritical condemnation and thirdly the act of public shaming itself. The poet is not guilty of the third but many of his readers share in his guilt of the first two. ${ }^{204}$

The poet is torn between sympathy, silence, guilt and revenge as he looks on at his contemporary atrocities of the tarring and feathering of Catholic women who associated with British soldiers. The wording also evokes the pitchcapping used by the British Military to torture Irish rebels during the 1798 rebellion. ${ }^{205}$ The poem was originally entitled Shame which comprised a double invocation to both the Catholic girls and Seamus' own name, implicating his guilt. He is helpless to prevent a re-enactment of the violence, revealing a subjugation of reason to religious, tribal instinct. He upholds the symbolic order while he simultaneously empathizes with that which threatens it. ${ }^{206}$

\section{"Strange Fruit"}

The title recalls the American folk song popularized by Billie Holiday which depicts the bodies of lynched African Americans hanging from the trees:

Here is the girl's head

Like an exhumed gourd.

Oval-faced, prune skinned, Prune-stones for teeth...

\footnotetext{
${ }^{203}$ Heaney, North, 30-1.

${ }^{204}$ Vendler, Seamus Heaney, 51.

${ }^{205}$ Pitchcapping, preceded by a crude shaving of the victim's head in order to maximise damage, was the act of pouring hot tar into a cap which was then placed on the victim's head, left to cool and subsequently ripped off along with the victim's scalp.

${ }^{206}$ Corcoran, The Poetry of Seamus Heaney, 74, Brearton, "Heaney and the Feminine," 77, Hart, "Poetymologies," 335-6, Foley, "Befitting Emblems of Adversity," 67-8, Alexander, "Femme Fatale," 230-2.
} 


\section{Diodorus Siculus confessed}

His gradual ease with the likes of this:

Murdered, forgotten, nameless, terrible.

Beheaded girl, outstaring axe,

And beautification, outstaring

What had begun to feel like reverence. ${ }^{207}$

The description of the girl's head spurs the poet to recognize an unhealthy similitude with Diodorus Siculus, who described the Celtic practice of severing enemy heads (Dio, Bib. Hist 29.4$).{ }^{208}$ The potential for renewal is checked by the physical reality of mutilation. He divulges their objectification through dismemberment and challenges his own voyeurism as the victim resists all attempts to beautify her:

The victim has finally regained agency, refusing to allow excavators to interpret her. In death she is master of her own body. This is an act of passive resistance which mimics the Long Kesh prison hunger strike protests. ${ }^{209}$

\section{"Kinship"}

Kinship is a hymn to the bog which completes Heaney's connection with Jutland by a direct invocation to Tacitus, a fellow witness of cultural turbulence:

And you, Tacitus,

Observe how I make my grove...

...a desolate peace.

\footnotetext{
${ }^{207}$ Heaney, North, 32.

208 "When their enemies fall, they cut off their heads and fasten them about the necks of their horses. ... The heads of their most distinguished enemies they embalm in cedar-oil and carefully preserve in a chest."

${ }^{209}$ Foley, "Befitting Emblems of Adversity," 68-9, Alexander, "Femme Fatale," 232, Rankin Russel, Seamus Heaney, 79-80, Corcoran, The Poetry of Seamus Heaney, 59.
} 
Our mother ground

Is sour with the blood

Of her faithful...

Come back to this

'island of the ocean'

Where nothing will suffice...

How we slaughter for the common good

And shave the heads

Of the notorious,

How the goddess swallows

Our love and terror. ${ }^{210}$

In an ode to the cult of Nerthus and Tacitus' chapter 40, he re-imagines Ireland in terms of Roman imperial conquest, subjected to the military force of an occupying army. He determines that no sacrifice is enough for the brutal cycle of violence which Tacitus, a mutual observer, likewise understands. However, the poet's search for kinship with Tacitus is futile as he must remain to face the reality of sectarian Ulster violence alone. ${ }^{211}$

\footnotetext{
${ }^{210}$ Heaney, North, 33-9.

${ }^{211}$ Foley, "Befitting Emblems of Adversity," 69, Collins, "Seamus Heaney: The Crisis of Identity," 103, Corcoran, The Poetry of Seamus Heaney, 75.
} 


\section{Literary Analysis}

\section{Heaney and the Feminists}

Feminist critiques of the bog poems draw upon the nature of gender and the question of voice.

\section{The Nature of Gender}

Heaney's gendered landscape is structured in terms of postcolonial writing. The description of his employment of gender stereotypes as unreflective and patriarchal is a gross simplification. ${ }^{212}$ The subversion of the bogs and frightening female embodiment (She tightened her torc on him/ And opened her fen) is itself a mode of resistance which must be rejected to uphold an order enacted by the male poet/excavator. ${ }^{213}$ Mythologization of the bog is founded upon its physical representation of national memory and the metaphor of digging up the past (Our pioneers keep striking/Inwards and downwards/Every layer they strip/Seems camped on before). ${ }^{214}$ Heaney's construction of the feminine is evident in the richness of the vowels and his depiction of the masculine in the acerbity of the consonants. The feminine is emotional, mysterious and inspirational while the masculine is rational, realistic, intellectual. The feminine represents otherness and its actions are intuitive, sensing, feeling. Both revered and feared, the female body is exalted yet never beyond masculine control (To where the dark-bowered queen/Whom I unpin/Is waiting.../ I unwrap skins and see/The pot of the skull.../I reach past.../ Dream of gold to the bullion/Of her Venus bone). ${ }^{215}$ Eroticization is inspired by myths of sexual fertility (the wind/On her naked front/It blows her nipples/To amber beads/It shakes the frail rigging/Of her ribs). ${ }^{216}$ The mother

\footnotetext{
${ }^{212}$ Hart, "Poetymologies," 210.

${ }^{213}$ Heaney, Wintering Out, 36-7.

${ }^{214}$ Heaney, Door Into the Dark, 55

${ }^{215}$ Heaney, North, 24.

${ }^{216}$ Heaney, North, 30-1.
} 
goddess of the bog is spouse (Her noose a ring), grim reaper (the tug/Of the halter at the nape), and nurturer (like a forceps baby) in a dubiously empowering representation of female power. ${ }^{217}$ She is conceptualized within a masculine perplexity to acknowledge autonomous female subjectivity. The torc ring in "The Tollund Man", associated with the cult of Nerthus due to its presence in votive bog deposits, represents potential regeneration through marriage and life cycles (seasons, birth and death). Heaney's self-constructed Mother Ireland goddess is typecast as a femme fatale who seduces her devotees toward a violent death which evokes republican sentiment (Our mother ground/Is sour with the blood/Of her faithful). ${ }^{218}$ Green highlights both Heaney's fear that the feminine principal is becoming less intrinsic and his desire to re-establish its relevance and spiritual coherence. He rejects the violence associated with her worship but sees potential in the union which sustains life. ${ }^{219}$ Coughlan believes Heaney's 'feminine' functions as the vehicle of myth and memory passage. She possesses hidden knowledge the masculine cannot expound; therefore, his self-discovery entails her defeat. $^{220}$

\section{The Feminine Voice}

The feminine never discovers its own voice but remains evoked, addressed, uncovered and revealed only by the masculine opposite. Heaney's feminine "other" is defined as the negative elaboration of the masculine subject. Brearton notes that voice is especially pertinent when female personae are adopted unsuccessfully, undermining the celebration of universality. ${ }^{221}$ Gender politics is side-lined by Heaney's politics of place and the women's cause is subordinated to national politics. On account of this, Heaney's feminine cannot be understood outside of its cultural context. Thus, the 'timelessness' of the bog adopts a contextual specificity within a Catholicism framework associated with republican tradition. The feminine, she asserts, reflects masculinity's psychological and historical crisis of Heaney's time. The requirement to bolster the masculine persona exposes masculine

\footnotetext{
${ }^{217}$ Heaney, North, 28-9, 30-1.

${ }^{218}$ Heaney, North, 33-9.

${ }^{219}$ Carlanda Green, “The Feminine Principle in Seamus Heaney's Poetry,” in Seamus Heaney: Modern Critical Views, ed. Harold Bloom (New York: Chelsea House Publishers, 1986), 3-5, 8, 10, 12.

${ }^{220}$ Carlanda Green, "The Feminine Principle," 3-5, 8, 10, 12, Coughlan, "Bog Queens," 186-8, 200, Hart, "Poetymologies," 210, 331, Alexander, "Femme Fatale," 219, 221-6.

${ }^{221}$ Brearton, "Heaney and the Feminine," 77-9, 81-3, 86, 88-9.
} 
anxieties. The absence of women as speaking subjects exposes his poetry as damagingly gendered. Although it must be considered that Heaney's conceptualizations of gender emerged from the late 60s-70s when now common placed notions of gender's social construction were entirely inconceivable. Therefore, modern feminist scholarship remains justly critical of Heaney, but he must be placed within his own historical and political context. $^{222}$

\section{Poetry's Social Function}

\section{Heaney's Sense of Inadequacy}

All of Heaney's anxieties and his sense of inadequacy must be placed within his own historic context. Heaney initially aligned himself with Catholic Nationalism and condemned the British government, Ulster police and the Loyalist movement in a heated article for the Listener in 1968. However, he began to realize the need for addressing the increasingly problematic situation less polemically as he pondered the polarities of Catholic/Protestant, Republican/Unionist, Celt/Anglo-Saxon. His confrontation with contemporary violence in Northern Ireland became a confrontation with his own poetics, provoking an early preoccupation with poetry's adequacy in its restorative function as a response to the crisis. His poems register as a consoling rationalization of suffering and reflect an emerging optimism. Simultaneously he repeatedly emphasized poetry's inadequacy to grasp historical reality. Heaney's own struggle with adequacy led him to question his motivations for composing political poetry. He takes an ontological understanding of poetry as a process stemming from a condition and sponsors the connection between individual and society, self and nature. However, the greater the public confrontation, the greater his sentiment of personal inadequacy. He discovered while reading Glob a correlative equivalent in the bog victims through which it is possible to intuitively view the human condition as a whole. He uses the bog victims to process his own cultural identity crisis. ${ }^{223}$

\footnotetext{
${ }^{222}$ Brearton, "Heaney and the Feminine," 77-9, 81-3, 86, 88-9.

${ }^{223}$ Brendan Corcoran, "Stalled in the Pre-Articulate: Heaney, Poetry and War," in The Oxford Handbook of British and Irish War Poetry, ed. Tim Kendall (Oxford: Oxford University Press, 2009), 691-2, Dennison, Seamus Heaney, 98, David Lloyd, "Pap for the Dispossessed: Seamus Heaney and the Poetics of Identity," Boundary 2 13, no.2/3 (Winter, 1985): 323-4, Foley, "Befitting Emblems of Adversity," 62-3.
} 


\section{Historical Accuracy}

North as the most sustained response to the Troubles, expresses Heaney's pursuit of mythopoetic constructs. These provide Heaney with a means to order his reality through universal tropes and introduce his central belief in the renewal of cultural memory. $\mathrm{He}$ transforms Nerthus into a territorial embodiment, signalling the strength of his commitment to substantiating cultural continuities of violence but also his disregard for historic legitimacy. This demonstrates the poet's power to forge widely separated correspondences, persistence of deep myth and archetypal patterns. There is an inherent dualism between poetry and reality, internal poetry and external politics. Thus, Dennison questions how poetry can fulfill an ameliorative function if it expresses a fundamentally violent historical reality. Poetry rooted in the past must adequately encompass divergent human experiences. He asserts that Heaney's present in continuity with the past fails to differentiate myth from history. Furthermore, his elements of continuity are not transformative but transfix on an image of violence, attempting to interpret and define the present by bringing it into significant relationship with the past. He believes in doing so they risk complacency in real recurrent violence. ${ }^{224}$ Yet Heaney never pertains to historic accuracy but openly acknowledges his invention of cultural and historical continuities as a means to establish his original intention; utilizing appropriate symbols found within archetypal antecedents of political violence to better comprehend, control and resolve present conflict. Glob's narrative of human sacrifice serves Heaney's imaginative association between an Iron Age fertility cult and the tradition of republican political martyrdom. ${ }^{225}$ Heaney's reading of literary tradition serves as a confrontation for Ireland who stands at a crossroads, armed with poetry as the decisive force enabling the people to consciously choose cultural renewal in the communal identity of an imagined Gaelic past. He believes poetry offers a resolution for a broken political identity. He poses the question of Irish identity, to which his answer is a deterritorialization of colonialism in national consciousness. Heaney seeks to re-establish indigenousness through reterritorializing Ireland's language and history. A return to mythical origins establishes a shared past and encourages a stronger communal identity through fuller self-possession. Locating a source of violence beyond sectarian division defines Irish identity

\footnotetext{
${ }^{224}$ Dennison, Seamus Heaney, 55-7, 59-62, 66-9.

${ }^{225}$ Foley, "Befitting Emblems of Adversity," 62-3, Collins, "Seamus Heaney: The Crisis of Identity," 52-3, McHale, "Archaeologies of Knowledge," 248.
} 
within a larger cultural milieu. Empathy for the bog victims stretches beyond identification to self-implication as Heaney recognizes the brutal nature of his own culture and his own complicities within it. Thus, Heaney serves as an example of cultivating positive narratives which may be used to construct a unifying identity. He recognizes his own imagining of the past and the power narratives hold for the betterment of humankind. ${ }^{226}$

\section{Heaney's Politics of Place}

Literary analyses of Heaney's bog poems have predominantly centered around his poetry of place and search for "befitting emblems of adversity." His poems may be archetyped as archaeological texts. Stratigraphical depth is visualized on the page through long, narrow passages as if digging into repressed mythic material. Metaphor is Heaney's preferred device to establish poetry as a dig. Dennison explains that Heaney's poetic relationship with reality is not only epistemological but an ethnical inquiry into ontology of a hermeneutical nature. ${ }^{227}$ The bog poems suggest a trans-temporal subconsciousness embedded in language. Heaney envisions writing as an expression of identity based on coherent unity. The act of selfproduction gives the writer representation and the reader liberation. Through the poet's experience of place, he is helplessly connected to the encroaching political crisis which he experiences as personal and is absorbed into his selfhood. The bog poems reflect Heaney's recoiling from the recursive terrors and counter-terrors of the $1970 \mathrm{~s}^{228}$

\section{Critiques Against his Politics of Place}

The general consensus of Wintering Out was that of a 'cop-out' sentiment. However, the text seeks to explore the deeper structures of present hostilities and the manner in which Protestant-Catholic divisions are embedded in language and topography, rather than to confer judgment. This inquiry was more fully explored in North which was further comprised of organized reflection, compelling realizations and meditative and verbally rich poetry. North integrates the complexity of association with the awareness that imperialist transgressions charge native landscapes. Much of its criticism lay in the exclusion of inter-sectarian issues

\footnotetext{
${ }^{226}$ Dennison, Seamus Heaney, 15,17, 20, 29-30, Parker, "Gleanings, Leavings," 27, Lloyd, "Pap for the Dispossessed," 319, 325, 327, 334-5, Collins, "Seamus Heaney: The Crisis of Identity,” 59, 111-2.

${ }^{227}$ Dennison, Seamus Heaney, 66, Hart, "Poetymologies," 206, 209, 331, 338-9.

${ }^{228}$ McHale, "Archaeologies of Knowledge," 243, 245, Guinn Batten, "Heaney’s Wordsworth and the Poetics of Displacement," in The Cambridge Companion to Seamus Heaney, ed. Bernard O'Donoghue (Cambridge: Cambridge University Press, 2008), 181-2, Corcoran, "Stalled in the Pre-Articulate," 686.
} 
by diverting the focus to Catholic immolation and savage tribal loyalty. However, Heaney is not excluding inter-sectarian issues but viewing them from a different perspective through metaphor. Longley adds accusations of historical determinism and a loyalist agenda rooted in plundering the past for parallels. ${ }^{229}$ Criticisms that accuse Heaney of romanticizing ancient violence overlook the developed analogy between Iron Age ritual murder and Ulster Troubles which explores the persistence of ideological myth in contemporary events. Foley points out that North was composed from Heaney's sense of demand to respond. ${ }^{230}$ Heaney embraces creativity as a viable alternative to violence. This is translated into images of bog victims offered as a meditative reflection which exposes the underlying bankrupt psychology of Ulstermen. Symbolism reveals the savage tribal instincts and barbarity inherent in conflict. Hancock asserts that despite Heaney's explicit forensic detail, he fails to create any realistic impression of suffering. Individual victims are subsumed by archetypes and individual perpetrators by ancient tribes with the result that the complexity of Northern Ireland is lost. His need to understand overrides rightful outrage. He further believes that North fails to grant the intensity of religious violence authenticity as irreconcilable ambitions tear it apart. ${ }^{231}$ In his exploration of the atavistic temptations of tribalism from his Catholic Nationalist standpoint, he has been accused of offering a sympathetic explanation for republican violence and either granting sectarian killing historic respectability or non-committedly evading the issue. This has led to the conclusion that Heaney reduces the Northern Irish reality to a quasipolitical mystique which endorses suffering as inevitable without political repercussion. ${ }^{232}$

\section{In Heaney's Defence}

Yet it seems entirely Heaney's intention to avoid superficial solutions to complex, intractable problems and propagandist agendas. To comprehend the psychological forces which render violence possible, it is necessary to transcend into the mythopoetic. Foley believes his ambivalence should be viewed rather as honest integrity. ${ }^{233}$ Furthermore, Heaney has been

\footnotetext{
${ }^{229}$ Edna Longley, “North: Inner Émigré or Artful Voyeur?” in The Art of Seamus Heaney, ed.Tony Curtis (Bridgend, Poetry Wales Press, 1982), 78, 83.

${ }^{230}$ Foley, "Befitting Emblems of Adversity," 61, 66.

${ }^{231}$ Hancock, “Daring to Make Free,”115-6.

232 Tobin, Passage to the Center, 69, Henry Hart, "Poetymologies”, 206, 209, Longley, “North: Inner Émigré or Artful Voyeur?" 78, 83, Edward Larrissy, "Hughes and Heaney," in The Cambridge History of English Poetry, ed. Michael O’Neill (Cambridge: Cambridge University Press, 2010), 933, Carruth, “On Bog Lands,” 240.

${ }^{233}$ Foley, "Befitting Emblems of Adversity," 70-1, 74.
} 
dubbed a nihilist on account of the overwhelming presence of atrocity but more recently scholars such as Tobin and Hart assert that by translating the dead as intelligible, he acknowledges that the atrocity of sectarian murder cannot be conveyed by words. ${ }^{234} \mathrm{He}$ denies language's adequacy to encompass suffering which illustrates a reverence and respect towards the victims rather than indifference. Thus, Heaney perfectly illustrates the issue with the human sacrifice interpretation of bog bodies. The attribution of ritualism in the role of the murders devalues the act of killing through religious justification. In his approach to "otherness" he demonstrates that a refusal to engage with the dead of others is to reject their humanity, stifling any growth or transformation. Therefore, the continuity between Iron Age and sectarian killing serves to shatter any fixed image of "otherness." Rather than avoiding conflict, Heaney insists on evaluating both factions critically in a humanistic attempt to promote open dialogue. His mythopoetics scrutinize the epistemological gap between history and myth and demythologizes the mystery of the bog victims. He exposes the consequences of blind devotion to fossilized ideologies. Thus, Heaney's use of myth serves an exploratory function, suggesting that historical narratives are ideological. It reveals their capacity for instigating divisive tribal and nationalistic factionalism. In his search for emblems which reveal the violent origins of culture, North demonstrates that cultural blindness drives violent reciprocity, maintained until the brutal logic of tribal myth is justified. Deconstructing the myth of "otherness" by interrogating its origins in our own culture exposes our own potential for disorder and allows us to break the cycle. ${ }^{235}$

\section{Conclusion}

In the bog poems Heaney explores mythopoetic constructs inspired by Glob's narratives and photographs as a response to the Troubles. Heaney develops an analogy between Iron Age ritual murders and Ulster to create what he deems "appropriate emblems of adversity." These allow him to symbolically order reality through timeless, universal tropes and archetypal patterns which suggest historical continuity of attachment to place, cultural consciousness

\footnotetext{
${ }^{234}$ Tobin, Passage to the Center, 106, 118, 124, Henry Hart, Seamus Heaney; Poet of Contrary Progressions (Syracuse: Syracuse University Press, 1992), 82, 87.

${ }^{235}$ Caldwell, "Joy in Night,” 110-11, Rankin Russel, Seamus Heaney, 71, 74.
} 
and renewed memory. The bog poems are a reflection of Heaney's identity crisis which stems from the struggle of existing within a fragmented society. As he grapples to deal with this, he attempts to define the present by bringing it into significant relationship with the past. His empathy with the bog victims travels beyond identification to self-implication as he recognizes the brutal nature of his culture and his own silent complacency. In "Bogland" the bog is introduced as a symbol for collective memory and identity grounded in communal violence. This metaphor is explored through an inward exploration into the bog whose bottomless center represents both the poet's and Ireland's history. "The Tollund Man" composes an intertextual dialogue with Glob wherein Tollund Man is portrayed as a close relative. Beauty and atrocity are juxtaposed as redemptive forces rooted in transformation and renewal. Heaney interweaves Glob's fertility sacrifices and Catholic hagiology into a transreligious/historic continuity as Tollund Man is exalted to a saintly status. In "Bog Queen" fertility is thematically developed when the bog becomes a vagina which is invoked through explicit sexual imagery. Heaney's conceptualization of sexual fertility spills into "The Grauballe Man" as he is transformed into a fetus. In "Punishment" the victim's frail beauty is described in precise sexual detail. Biblical allusions solidify the artful voyeur's guilt within a framework of his own religious ideology. Complacently he observes and consumes her just as he does the tarring of his Catholic sisters, illustrating subjugation to tribal instincts over reason. Contrarily in "Strange Fruit" voyeurism is challenged and then dismissed through her rejection of objectification. "Kinship" returns to Glob's interpretational narratives by invoking Tacitus as a fellow witness to Nerthus and Heaney reimagines Ireland under Roman imperial conquest. However, Heaney's search for kinship with Tacitus proves futile and the poem ends on a note of despair and disillusionment. Heaney has been much criticized, most recently by a newly emerging and extremely valuable feminist dialogue which explores the previously unaddressed question of gender and sexuality within the poems. Nerthus is assimilated into a representation of Ireland rooted in the bog. Mother Ireland is depicted as a femme fatale reproduced from republican sentiment. The female body is both revered and feared but consistently controlled by the male poet. Brearton highlights a complete absence of female voice, her persona revealed only by contrast to the masculine and defined by her "otherness." ${ }^{236}$ Heaney's gender politics, reflective of his socio-historical context, is utterly side-lined by politics of place. In his politics of place, he seeks to explore the underlying

\footnotetext{
${ }^{236}$ Brearton, "Heaney and the Feminine," 77.
} 
psychology of violent perpetrators in order to understand the structure of present hostilities. In doing so he has been accused of offering a sympathetic explanation for republican violence, granting sectarian killing historic respectability and reducing Northern Ireland's reality to a quasi-political mysticism. Longley accuses Heaney of historical determinism in plundering the past for parallels that feature republican loyalist ideologies and asserting that violence and suffering are not only naturally humanly innate but inevitable. ${ }^{237}$ However, more recently scholars such as Tobin, Foley, Hart and Collins acknowledge Heaney's use of myth as a metaphor to embrace the complexity of human conflict, which cannot be conveyed within the paradigm of words. They also believe his ambivalence demonstrates honest integrity, rather than indifference. ${ }^{238}$ Heaney insists on evaluating both sides critically in a humanistic attempt to promote dialogue between warring factions. Through engaging with the bog victims, or the dead of others, we shatter any fixed image of "otherness" and embrace diversity. Heaney illustrates that the attribution of ritualism in the act of killing diminishes the atrocity through ideological justification. This has significant implications in the interpretational narratives of the bog victims. Myth for Heaney serves an exploratory purpose, revealing that cultural blindness permits reciprocal violence in a toxic cycle until violence is justified by the brutally flawed logic of tribal myth. Deconstructing myth by interrogating our own cultural origins breaks the cycle of disorder. Heaney has acknowledged that his mythopoetics are not historically accurate but are useful for the purpose of cultural restoration and he uses them to forge a unifying cultural identity grounded in a renewal of the past. His message is one of hope. Therefore, 50 years ago Heaney was able to recognize the significance of self-constructed narratives imposed onto the past and understand their role in undermining the concept of violence as innate to indigenous culture. This is an area that remains under-researched today in the scholarly discussion of bog bodies.

\footnotetext{
${ }^{237}$ Longley, “North: Inner Émigré or Artful Voyeur?” 78, 83.

238 Tobin, Passage to the Center, 106, 118, 124, Foley, "Befitting Emblems of Adversity," 62-3, 70-1, Hart, Seamus Heaney, " 82, 87, Collins, "Seamus Heaney: The Crisis of Identity," 59, 111-2.
} 


\section{Bog Bodies: The Future of Research}

The development of Heaney's bog poetics may be traced from the bog poems to their culmination of "The Tollund Man in springtime." Despite the fact that after the resolution of the Troubles Heaney no longer required any "befitting emblems of adversity," his pertinence to the figure of Tollund Man continued into District and Circle (2006), wherein he no longer identifies Tollund Man as an uncle, but as himself. His poetry completes a full cycle as he himself becomes a bog body in the context of the ever-changing modern age. He positions Tollund Man within new conceptual terrain but re-imagined as a mediating figure between the vast evolutionary timescale of ecosystems starkly contrasted against the modern breakneck paced economy. Nostalgia for the ancient past persists as metropolitan screens interweave with bog seeding grasses:

Into your virtual city I'll have passed

Unregistered by scans, screens, hidden eyes,

... Out under the seeding grass

And trickles of kesh water, sphagnum moss...

He enters civilization as a disembodied shopper and museum-turned tourist attraction. Once strongly connected to the natural environment, Tollund Man has become a consumed commodity:

In the end I gathered

From the display-case peat my staying powers,

Told my...old uncallused hands to be young sward,

The spade-cut skin to heal...

I smelled the air, exhaust fumes, silage reek,

Heard from my heather bed the thickened traffic...

Here Heaney seems to question whether technology materially inhibits our connection to a sense of place and the embodiment of traditional knowledge. The poem traverses from his reevoked childhood memories of a pre-electric agrarian past to a capitalist industrial society. 
Heaney measures the trajectory of Irish society as he has experienced it within his own lifetime. As in the bog poems, he continues to overlay historical consciousness onto the $21^{\text {st }}$ century present. He rejects the present direction of society by re-asserting the same bonds to place which characterized his childhood. However, he weaponizes connection to the land, not by reminiscing about the past but by forging a new era between ecology and technology: ${ }^{239}$

As a man would, cutting turf,

I straightened, spat on my hands, feit benefit

And spirited myself into the street. ${ }^{240}$

Throughout the entirety of his lifelong career the bog bodies provided for Heaney a historical basis upon which to construct Irish identity by superimposing his present onto the past. Heaney's demonstration of creating positive, hope-fuelled narratives may be exhorted as an ideal example in seizing control of communal dialogue and changing the tone of the discussion. Currently the interpretational narratives surrounding bog bodies predominantly diminish the rich spatial-temporal diversity of the archaeological record in favor of blanket generalizations such as human sacrifice, mugging victims or executed criminals. These tend to over-exaggerate violence and ritualism. In the absence of textual sources (excluding Tacitus whose historical accuracy and reliability has been brought into question), an alternative might be rather to acknowledge an absence of facts while emphasizing investigative limitations. A revision to previous research, especially in the case of Lindow Man (in regard to both dating and paleopathology), is sorely needed. Asingh and Lynnerup's re-investigation of Grauballe Man has especially demonstrated the need to more accurately determine paleopathology thereby eliminating pseudo-pathologies which obscure narratives and drive false assumptions. ${ }^{241}$ Adopting a more case-by-case approach derived from empirical analyses would allow for greater comparison between examples. Individuals would be empirically contextualized within the entire record. Data could be gathered on percentages of individual pathologies, diverse causes of death, the presence of artifacts and textiles, gender and age. There might be further exploration into paleo-environmental reconstruction

\footnotetext{
${ }^{239}$ Carruth, "On Bog Lands,” 240-2.

${ }^{240}$ Seamus Heaney, District e Circle (Milan: Mondadori, 2009), 116, 120, 122.

${ }^{241}$ Asingh, Lynnerup, Grauballe Man: An Iron Age Bog Body Revisited (Jutland: Narayana Press: 2007), 9-273.
} 
and expanding data sets past simply the depositional locus which would aid in reconstructing narratives and add more multi-disciplinary discussion, meaning a greater diversity of perspectives. Another concept which could be queried is the question of whether hysteria surrounding ritual has ignored the brutality of non-ritual death and has served to overdetermine these deaths as special or metaphysical, allowing for a mystical exaltation of the killers. The ritualization of murder tends to downplay suffering on an individual level, including the victim's experience of pain. The perception of pain is a topic initiated by Chapman and Gearey but more discussion is warranted to explore intentionality behind brutality, such as if violence may be measured by proxy of pain thresholds. ${ }^{242}$ The author believes that the interpretation of a ritualistic death degrades the act of killing by shrouding the perpetrators in a cloud of mystery. This desensitizes us to its abhorrence and hinders our ability to empathize with the victims. Heaney advocated for empathizing with the dead of others in order to undermine the ideology which justifies violence, thereby breaking the toxic sectarianist cycle. Therefore, the evolutionary myth of an excessively violent past defined by brutal and uncivilized natives is negated by the fact that violence is shown to be justified both in the past and present by ideological frameworks which may be dismantled. The occurrence of human sacrifice in the past was likely very scarce, thus even more so should its presence be within the archaeological record on account of preservation bias. Despite this, many bog bodies have been ascribed to human sacrifice. While it is likely some are, many are also not and there appears to be over-ascription. However, even in the instances of human sacrifice, the act itself does not define those societies as inherently violent, as Heaney has demonstrated by his comparison with $20^{\text {th }}$-century Irish society. For example, contemporary Irish society today cannot be deemed definably violent but more than anything as resilient and overcoming. Ultimately, brutality should be judged on the level of the individual. It remains unknown exactly how many bog victims were undeniably violently killed; how many may have died violently and how many did not. These percentages would enable further corrective work regarding sensationalist narratives. Assumptions over ritual violence reflect rather our own preconceived and sometimes prejudiced notions toward indigenous Iron Age societies, partially imparted into western tradition by Roman imperialists. This has real-life implications for minorities such as contemporary Druids in British society. 50 years ago, Heaney recognized the value in constructing positive historical narratives. Perhaps it is time to change the tone of our discussion to extend beyond ritualism.

${ }^{242}$ Chapman, Gearey, "Towards an Archaeology of Pain?” 214-5, $219-24$. 


\section{Bibliography}

Ahrenholt-Bindslev, Dorthe, Josephsen, Kaj, and Grethe Jurik, Anne. "Grauballe Man's Teeth and Jaws." In Grauballe Man: An Iron Age Bog Body Revisited, edited by Pauline Asingh, Niels Lynnerup, 140-153. Jutland: Narayana Press, 2007.

Alberge, Dalya. "Lindow Man was a Simple Murder Victim.” The Times, March 22, 2004.

Alberti, J.M.M, Bienkowski, Piotr, and Chapman, Malcolm. "Should we Display the Dead?" Museum and Society 7, no.3 (Nov. 2009): 133-149.

Aldhouse-Green, Miranda. "Chaining and Shaming: Images of Defeat, from Llyn Cerrig Bach to Sarmitzegetusa." Oxford Journal of Archaeology 23, no. 3 (2004): 319-340.

Aldhouse-Green, Miranda. Bog Bodies Uncovered; Solving Europe's Ancient Mystery. London: Thames \& Hudson, 2015.

Alexander, Stephanie. "Femme Fatale: The Violent Feminine Pastoral of Seamus Heaney's North." The Canadian Journal of Irish Studies 39, no.2 (2016): 218-235.

Andreas Harild, Jan, Earle Robinson, David, and Hudlesbusch, Jesper. "New Analyses of Grauballe Man's Gut Contents." In Grauballe Man: An Iron Age Bog Body Revisited, edited by Pauline Asingh, Niels Lynnerup, 154-187. Jutland: Narayana Press, 2007.

Asingh, Pauline. Grauballe Man-Portrait of a Bog Body. Copenhagen: Gyldendalske, 2009.

Asingh, Pauline. "The Man in the Bog," in Grauballe Man: An Iron Age Bog Body Revisited, edited by Pauline Asingh, Niels Lynnerup, 14-31. Jutland: Narayana Press, 2007.

Asingh, Pauline, Lynnerup, Niels "Foreword," in Grauballe Man: An Iron Age Bog Body Revisited, edited by Pauline Asingh, Niels Lynnerup, 9-13. Jutland: Narayana Press, 2007.

Aufderheide, Arthur. "Soft Tissue Taphonomy: A Paleopathology Perspective." International Journal of Paleopathology 1, no.2 (Oct. 2011): 75-80.

Bahn, Paul. "Through Nature to Eternity; the Bog Bodies of Northwest Europe by Wijnand Van Der Sanden." Archaeology 50, no.4 (Jul. 1997): 62-67.

Bahn, Paul. "Do not Disturb? Archaeology and the Rights of the Dead." Journal of Applied Philosophy 1, no.2 (1984): 213-225.

Batten, Guinn. "Heaney's Wordsworth and the Poetics of Displacement." In The Cambridge Companion to Seamus Heaney, edited by Bernard O’Donoghue. Cambridge: Cambridge University Press, 2008.

Benario, Herbert. "Tacitus' "Germania" and Modern Germany." Illinois Classical Studies 15, no.1 (Spring 1990): 163-174. 
Boyd, Williard. "Museums as Centres of Controversy." Daedalus 128, no.3 (Summer 1999): 185228.

Brearton, Fran. "Heaney and the Feminine." In The Cambridge Companion to Seamus Heaney, edited by Bernard O’Donoghue. 73-91. Cambridge: Cambridge University Press, 2008.

Brennan, Bridget. "The Influence of Shamanic Practice on the Deposition of Prehistoric Remains in Bogs.” Ph.D. diss., Institute of Technology, Sligo, 2014.

Briggs, Elizabeth, and Mulhall, Isabella. "Presenting a Past Society to a Present Day Audience: Bog Bodies in Iron Age Ireland.” Museum Ireland, 2007.

Brothwell, Don. The Bog Man and the Archaeology of People. London: British Museum Publications, 1986.

Brothwell, Don. “Grauballe Man: An Iron Age Bog Body Revisited-Review,” Antiquity 82 (2008): 227.

Brown, Pete. "Us and them: Who Benefits from Experimental Exhibition Making?" Museum Management and Curatorship 26, no. 2 (2011): 129-148.

Browne, Malcolm. "Body from British Bog Tells Tale of 2,200-Year-Old Human Sacrifice; Tests show Druid's Last Meal Cooked 8 Minutes." The Gazette, March 20, 1988.

Burch, Stuart. "Lindow Man: A Bog Mystery, Manchester Museum.” Museums Journal 108 (2008):46-9.

Caldwell, Caleb. "Joy in Night: Witness and the Limits of Discourse in Seamus Heaney's North." Religion \& Literature 45, no. 1 (2013): 103-129.

Carruth, Allison. "On Bog Lands and Digital Markets: Seamus Heaney's Recent Poetry." Pacific Coast Philology 46, no. 2 (2011): 232-244.

Chapman, H. "The Landscape Archaeology of Bog Bodies." Journal of Wetland Archaeology 15 (2015): 109-121.

Chapman, Henry, and Gearey, Benjamin. "Towards an Archaeology of Pain? Assessing the Evidence from Later Prehistoric Bog Bodies." Oxford Journal of Archaeology 38, no. 2 (2019): 214227.

Charlier, P. Nielsen, O. and Lowenstein, E.J. "Plantar Warts on Tollund Man's Feet (Denmark $4^{\text {th }}$ Century BC). Limits of Retrospective Dermatological Diagnosis." Clinical and Experimental Dermatology 42 (2017): 547-548.

CoBDO, "Request for the Reburial of Human Remains and Grave Goods, Avebury." Accessed June $22,2020$. 
https://www.academia.edu/12766795/Request for the Reburial of Ancestral Human Rem ains at Avebury Wiltshire 2008 ?auto=download.

Collins, Floyd Green. "Seamus Heaney: The Crisis of Identity.” Ph.D. diss., University of Arkansas, 1997.

Connolly, R.C. "Lindow Man: Britain's Prehistoric Bog Body." Anthropology Today 1, no.5 (Oct. 1985): 15-17.

Corcoran, Brendan. "Stalled in the Pre-Articulate: Heaney, Poetry and War." In The Oxford Handbook of British and Irish War Poetry, edited by Tim Kendall, 684-705. Oxford: Oxford University Press, 2009.

Corcoran, Neil. The Poetry of Seamus Heaney; A Critical Study. London: Faber and Faber, 1998.

Coughlan, Patricia. "Bog Queens: The Representation of Women in the Poetry of John Montague and Seamus Heaney." In Seamus Heaney, edited by M. Allen, 185-205. London: Palgrave Macmillan, 1997.

Cox, Marie, and McAdam, Matt. "Bog Bodies and Bull Scrota." Archaeology 63, no. 4 (2010): 8.

Dennison, John. Seamus Heaney and the Adequacy of Poetry. Oxford: Oxford University Press, 2015.

Diodorus Siculus. The Library of History. Translated by C.H. Oldfather. Cambridge: Harvard University Press, 1989.

Fagan, Brian. "Archeology: The Life and Death of a Druid Prince: The Story of Lindow Man, an Archaeological Sensation. Anne Ross and Don Robins." American Anthropologist 93, no. 3 (1991): 738.

Fawbie Info. "Nerthus.” Accessed January 24, 2020. https://fawbie.info/wintering-out/nerthus/

Foley, Andrew. "'Befitting Emblems of Adversity': The Bog Poems of Seamus Heaney." English Studies in Africa 41, no. 1 (1998): 61-75.

Fredengren, Christina. "Becoming Bog Bodies Sacrifice and Politics of Exclusion, as Evidenced in the Deposition of Skeletal Remains in Wetlands Near Uppåkra." Journal of Wetland Archaeology 18, no. 1 (2018): 1-19.

Frederiksen, Jesper, and Glastrup, Jens. "Conservation and Analysis of Grauballe Man 2001-2002." In Grauballe Man: An Iron Age Bog Body Revisited, edited by Pauline Asingh, Niels Lynnerup, 58-77. Jutland: Narayana Press, 2007.

Giles, Melanie. "Iron Age Bog Bodies of North-Western Europe, Representing the Dead." Archaeological Dialogues 16, no.1 (2009): 75-101.

Giles, Melanie. "Performing Pain, Performing Beauty: Dealing with Difficult Death in the Iron Age." Cambridge Archaeological Journal 25, no.3 (Jul. 2014): 539-550. 
Gill-Robinson, Heather. The Iron Age Bog Bodies of the Archaeologisches Landesmuseum, Schloss Gottorf, Schleswig, Germany. ProQuest Dissertations Publishing, 2005.

Gill-Robinson, Heather. "Bog Bodies on Display.” Journal of Wetland Archaeology 4, no.1 (2004): 111-116.

Glob, P.V. The Bog People: Iron Age Man Preserved. New York: Faber \& Faber, 1965.

Gowlett, J. A. J., Hedges, R. E. M., and Law, I. A. "Radiocarbon Accelerator (AMS) Dating of Lindow Man.” Antiquity 63 (1989): 71-79.

Granite, Guinevere. "Understanding the Death and Burial of Northern European Bog Bodies." In Diversity to Sacrifice; Form and Function of Sacrificial Practices in the Ancient World and Beyond, edited by Carrie Ann Murray, 211-222. New York: State University of New York Press, 2016.

Green, Carlanda. "The Feminine Principle in Seamus Heaney’s Poetry." In Seamus Heaney: Modern Critical Views, edited by Harold Bloom, 3-13. New York: Chelsea House Publishers, 1986.

Green, Miranda. "Humans as Ritual Victims in the Later Prehistory of Western Europe." Oxford Journal of Archaeology 17, no.2 (1998): 169-189.

Gregersen, Markil, Grethe Jurik, Anne, and Lynnerup, Niels. "Forensic Evidence, Injuries and Cause of Death," in Grauballe Man: an Iron Age Bog Body Revisited, edited by Pauline Asingh, Niels Lynnerup, 234-259. Jutland: Narayana Press, 2007.

Grethe Jurik, Anne. "New Radiological Examinations.” In Grauballe Man: An Iron Age Bog Body Revisited, edited by Pauline Asingh, Niels Lynnerup, 94-109. Jutland: Narayana Press, 2007.

Gruen, Erich. Rethinking the Other in Antiquity. Princeton: Princeton University Press, 2011.

Hamilton, Ian., and Noel-Tod, Jeremy. The Oxford Companion to Modern Poetry. Oxford: Oxford University Press, 2013.

Hancock, Tim. "Daring to make Free: Seamus Heaney and Ulster Politics, 1968-1979." English 47, (1998): 111-126.

Harris, Neil. "Museums and Controversy: Some Introductory Reflections." The Journal of American History 82, no. 3. (Dec. 1995): 1102-1110.

Hart, Henry. "Poetymologies in Seamus Heaney's Wintering Out." Twentieth Century Literature 35, no. 2 (1989): 204-231.

Hart, Henry. Seamus Heaney; Poet of Contrary Progressions. Syracuse: Syracuse University Press, 1992.

Haynes, Holly. “Tacitus’ Dangerous Word.” Classical Antiquity 23, no.1 (April 2004): 33-61.

Heaney, Seamus. Door Into the Dark. London: Faber and Faber, 1969. 
Heaney, Seamus. Wintering Out. London: Faber and Faber, 1972.

Heaney, Seamus. North. London: Faber and Faber, 1975.

Heinemeir, Jan, and Asingh, Pauline. "Dating of Grauballe Man." In Grauballe Man: An Iron Age Bog Body Revisited, edited by Pauline Asingh, Niels Lynnerup, 196-201. Jutland: Narayana Press, 2007.

Herodotus. Histories. Translated by A.D. Godley. Cambridge: Harvard University Press, 1920.

Heumann Gurian, Elaine. Civilizing the Museum. London: Routledge, 2006.

Hutton, Ronald. "Why does Lindow Man Matter?" Time and Mind 4, no. 2 (2011): 135-148.

James, N. "Repatriation, Display and Interpretation." Antiquity 82 (2008): 770-777.

Janes, Robert. Museums in a Troubled World. New York: Routledge, 2009.

Jarcho, S. "Tollund Man and Other Bog Burials." Bulletin of the New York Academy of Medicine 46, no. 7 (Jul. 1970): 554-557.

Jones, Jonathon. "Riddle of the Bog." The Guardian, June 21, 2007. https://www.theguardian.com/artanddesign/2007/jun/21/heritage.jonathanjones

Joy, J. Lindow Man. London: The British Museum Press, 2009.

Kelly, Eamonn. "An Archaeological Interpretation of Irish Iron Age Bog Bodies." In The Archaeology of Violence: Interdisciplinary Approaches, edited by S. Ralph, 232-40. New York: State University of New York Press, 2012.

Keys, David. "Europe's First Mummies." Archaeology 56, no. 5 (2003): 16-17.

Koch, Mogens, Scharff, Mikkel. "Infared Reflectography (IRr) Surface Analysis.” In Grauballe Man: An Iron Age Bog Body Revisited, edited by Pauline Asingh, Niels Lynnerup, 78-83. Jutland: Narayana Press, 2007.

Krebs, Christopher. “The Continuing Message.” History Today, September, 2011.

Kruse, Aksel. "Endoscopic Examination of Grauballe Man.” In Grauballe Man: An Iron Age Bog Body Revisited, edited by Pauline Asingh, Niels Lynnerup, 124-129. Jutland: Narayana Press, 2007.

Larrissy, Edward. "Hughes and Heaney." In The Cambridge History of English Poetry, edited by Michael O’Neill, 918-934. Cambridge: Cambridge University Press, 2010.

Larsen, Rene, Vestergaard Poulsen, Dorte. “Analysis of the Skin.” In Grauballe Man: An Iron Age Bog Body Revisited, edited by Pauline Asingh, Niels Lynnerup, 84-93. Jutland: Narayana Press, 2007.

Lobell, Jarrett. and Patel, Samir. "Bog Bodies Rediscovered." Archaeology 63, no. 3 (2010): 22-29. 
Longley, Edna. “North: Inner Émigré or Artful Voyeur?” In The Art of Seamus Heaney, edited by Tony Curtis, 63-96. Bridgend, Poetry Wales Press, 1982.

Lloyd, David. ""Pap for the Dispossessed": Seamus Heaney and the Poetics of Identity." Boundary 2 13, no. 2/3 (Winter, 1985): 319-342.

Luce, T.J. "Tacitus' Conception of Historical Change: The Problem of Discovering the Historian's Opinions." In Oxford Readings in Classical Studies; Tacitus, edited by Rhiannon Ash, 339356. Oxford: Oxford University Press, 2012.

Lynnerup, Niels. "Methods in Mummy Research." Anthropologischer Anzeiger 67, no. 4 (2009): 357-384.

Lynnerup, Niels. "Bog Bodies." Anatomical Record 298, no. 6 (2015): 1007-1012.

Lynnerup, Niels. "Medical Imaging of Mummies and Bog Bodies-A Mini-Review," Gerontology 56 (2010): 441-448.

Lynnerup, Niels, Lier Boldsen, Jesper, and Grethe Jurik, Anne. "The Biological Anthropology of Grauballe Man," in Grauballe Man: An Iron Age Bog Body Revisited, edited by Pauline Asingh, Niels Lynnerup, 226-233. Jutland: Narayana Press, 2007.

Lynnerup, Niels, Grether Jurik, Anne, Dalstra, Michel, and Bergholdt Hansen, Rolf. "CT-scanning, 3D Visualisations and Stereolithography." In Grauballe Man: An Iron Age Bog Body Revisited, edited by Pauline Asingh, Niels Lynnerup, 110-123. Jutland: Narayana Press, 2007.

Menon, Shanti. "The People of the Bog.” Discover, August, 1997.

McHale, Brian. "Archaeologies of Knowledge: Hill's Middens, Heaney's Bogs, Schwerner's Tablets." New Literary History 49, no.1 (Winter, 1999): 239-62.

McLean, Stuart. "Bodies from the Bog: Metamorphosis, Non-Human Agency and the Making of 'Collective Memory," Trames 12, no. 3 (2008): 299-308.

Mitchell, John. "Role of Polysaccharides in the Preservation of Bodies in Peat." Polymers 29 (1996): 193.

Mulhall, Isabella. "The Peat Men from Clonycavan and Oldcroghan.” British Archaeology, January/February, 2010.

Mulhall, Isabella, and Briggs, Elizabeth. "Presenting a Past Society to a Present Day Audience: Bog Bodies in Iron Age Ireland.” Museum Ireland 17 (2007): 71-81.

Museum Silkeborg. "The Discovery of Tollund Man,” Accessed June 31, 2019. http://www.museumsilkeborg.dk/the-discovery-of-tollund-man.

Museum Silkeborg. "By Horse-Drawn Carriage and Train to the National Museum," Accessed June 31, 2019.

http://www.museumsilkeborg.dk/by-horse-drawn-carriage-and-train-to-the-national-museum, 
Museum Silkeborg. "Preservation of Tollund Man.” Accessed June 31, 2019.

http://www.museumsilkeborg.dk/preservation-of-tollund-man.

Museum Silkeborg. "The Latest News About Tollund Man.” Accessed June 31, 2019.

http://www.museumsilkeborg.dk/the-latest-news-about-tollund-man

Nielson, Nina, Phillippsen, Bente, Kanstrup, Marie, Olsen, Jesper. "Diet and Radiocarbon Dating of Tollund Man: New Analyses of an Iron Age Bog Body from Denmark," Radiocarbon 60, no. 5 (June 2017): 1533-1545.

O'Donoghue, Bernard. "Introduction." In The Cambridge Companion to Seamus Heaney, edited by Bernard O’Donoghue, 1-18. Cambridge: Cambridge University Press, 2008.

O'Gorman, Ellen. "No Place like Rome: Identity and Difference in the Germania of Tacitus." In Oxford Readings in Classical Studies; Tacitus, edited by Rhiannon Ash, 95-118. Oxford: Oxford University Press, 2012.

Orosius. Historiarum adversum paganos. Translated by C. Zangemeister. Teubner, 1889.

Parini, Jay. “The Bog Poet.” The Nation, January 4, 1999.

Parker, Michael “Gleanings, Leavings: Irish and American Influences on Seamus Heaney's 'Wintering Out' 1972.” New Hibernia Review 2, no.3 (Autumn, 1998): 16-35.

Parker- Pearson, M. "Lindow Man and the Danish Connection: Further Light on the Mystery of the Bogman.” Anthropology Today 2, no.1 (February 1986): 15-18.

Pliny The Elder. Natural History. Translated by John Bostock. London: Taylor and Francis, 1855.

Purdy, A. "Unearthing the Past: The Archaeology of Bog Bodies in Glob, Atwood, Hébert and Drabble." Textual Practice 16, no. 3 (2002): 443-458.

Rankin Russell, Richard. Seamus Heaney; An Introduction. Edinburgh: Edinburgh University Press, 2016.

Rankin Russel, Richard. "The Black and Green Atlantic: Violence, History and Memory in Natasha Tretheway's "South" and Seamus Heaney's "North."” The Southern Literary Journal 46, no.2 (Spring, 2014): 155-172.

Ravn, Morten. "Bog Bodies-A Burial Practice during the Early Iron Age?” In The Iron Age on Zealand; Status and Perspectives, edited by Linda Boye, 83-89. Copenhagen: The Royal Society of Northern Antiquaries, 2011.

Ravn, Morten. "Burials in Bogs; Bronze and Early Iron Age Bog Bodies from Denmark." Acta Archaeologica 81, no.1 (2010): 106-117.

Ross, Anne. The Life and Death of a Druid Prince: The Story of Lindow Man, an Archaeological Sensation. New York: Summit Books, 1989. 
Sanders, Karin. Bodies in the Bog and the Archaeological Imagination. Chicago: University of Chicago Press, 2012.

Scarre, Geoffrey. “Archaeology and Respect for the Dead." Journal of Applied Philosophy 20, no.3 (2003): 237-249.

Skoglund, Peter. "Diet, Cooking and Cosmology: Interpreting the Evidence from Bronze Age Plant Macrofossils." Current Swedish Archaeology 7 (1999): 149-160.

Sidonius Apollinaris. Epistulae et Carmina. Translated by Christianus Luetjohann. Berlin: Weidmann, 1887.

Sitch, Bryan. "Courting Controversy-The Lindow Man Exhibition at the Manchester Museum." University Museums and Collections Journal 2 (2009): 51-54.

Stephanie, Alexander. "Femme Fatale: The Violent Feminine Pastoral of Seamus Heaney's North." The Canadian Journal of Irish Studies 39, no. 2 (2016): 218-235.

Stodkilde-Jorgensen, Hans, Jacobsen, Niels Otto, Warncke, Esbern, and Heinemeier, Jan. "The Intestines of a More than 2000 Years Old Peat-Bog Man: Microscopy, Magnetic Resonance Imaging and 14C-Dating." Journal of Archaeological Science 35 (London: 2008): 530-534.

Strabo. Geography. Translated by H. L. Jones, Cambridge: Harvard University Press, 1924.

Strehle, Helle. "The Conservation of Grauballe Man.” In Grauballe Man: An Iron Age Bog Body Revisited, edited by Pauline Asingh, Niels Lynnerup, 32-51. Jutland: Narayana Press, 2007.

Tacitus, Germania. Translated by J.B Rives. Oxford: Clarendon Press, 1999.

Tacitus, Germania, Translated by J.C.G Anderson. Oxford: Oxford University Press, 1997.

The Holy Bible, New International Version. Minto: The Bible Society in Australia, 2008.

Thomas, Richard "The Germania as Literary Text." In The Cambridge Companion to Tacitus, edited by A.J Woodman. Cambridge: Cambridge University Press, 2009.

Tobin, Daniel. Passage to the Center: Imagination and the Sacred in the Poetry of Seamus Heaney. Lexington: University Press of Kentucky, 1999.

Van der Plicht, Van der Sanden, W. A. B., Aerts, A. T., and Streurman, H. J. "Dating Bog Bodies by Means of 14C-AMS.” Journal of Archaeological Science 31, no.4 (April 2004): 471-491.

Vendler, Helen. Seamus Heaney. London: Fontana Press, 1998.

Villa, Chiara, and Lynnerup, Niels. "Hounsfield Units Ranges in CT-scans of Bog Bodies and Mummies." Anthropologischer Anzeiger 69, no.2 (March 2012): 127-145. 
Walker Laird, Pamela. “The Public's Historians.” Technology and Culture 39, no.3 (Jul. 1998): 474482.

Warner Boel, Lene, and Dalstra, Michel. "Microscopical Analyses of Bone Specimens; Structural Changes Related to Chronological Age and Possible Diseases.” In Grauballe Man: An Iron Age Bog Body Revisited, edited by Pauline Asingh, Niels Lynnerup, 130-139. Jutland: Narayana Press, 2007.

Wilkinson, Caroline. "Facial Reconstruction of Grauballe Man.” In Grauballe Man: An Iron Age Bog Body Revisited, edited by Pauline Asingh, Niels Lynnerup, 260-273. Jutland: Narayana Press, 2007.

Wilkinson, T.M. "Last Rights: The Ethics of Research on the Dead." Journal of Applied Philosophy 19, no.1 (2002): 31-39.

Wilson, Andrew S., Richards, Michael P., Stern, Ben., Janaway, Robert C., Pollard, A. Mark, and Tobin, Desmond J. "Information on Grauballe Man from his Hair." In Grauballe Man: An Iron Age Bog Body Revisited, edited by Pauline Asingh, Niels Lynnerup, 188-195. Jutland: Narayana Press, 2007.

Wood, Juliette. "Dying for the Gods: Human Sacrifice in Iron Age and Roman Britain." Folklore 114, no. 1 (April 2003): 129-130. 
